\title{
4. PETROLOGY AND CHEMISTRY OF BASALTIC ROCKS FROM HOLE 396B, IPOD/DSDP LEG 46
}

\author{
Hiroaki Sato, Department of Earth Sciences, Faculty of Sciences, Kanazawa University, Kanazawa, Japan \\ Ken-ichiro Aoki, Department of Petrology, Mineralogy, and Economic Geology, Tohoku University, Sendai, Japan \\ Kenji Okamoto, Department of Geological Sciences, Faculty of Liberal Arts and Sciences \\ University of Osaka Prefecture, Osaka, Japan \\ and \\ Bun-ya Fujita, Department of Earth Sciences, Faculty of Sciences, Kanazawa University, Kanazawa, Japan
}

\section{INTRODUCTION}

Leg 46 of the International Phase of Ocean Drilling (IPOD) successfully penetrated 255 meters of basaltic basement at Hole 396B, 150 kilometers east of the axis of the Mid-Atlantic Ridge at $22^{\circ} 59.14^{\prime}$ North (Figure 1). We recovered basalts, typical of the ocean floor, that consist primarily of sparsely-phyric olivine-plagioclase basalt (total phenocryst content, $<1 \%$ ) and phyric Cr-spinel-bearing olivine-plagioclase basalt (total phenocryst content, 15 to 25\%). As shown in Figure 2, these rocks may be divided according to the following three methods: lithologic (4 units; although the shipboard party defined 8 , site chapter of this volume), chemical (7 units), and magnetic (4 units). In this paper, we present petrographic and chemical data on these rocks to show the diversity of basalts within and among chemical units; additionally, we discuss an estimation of temperature of magmas, the crystallization history of phenocrysts, and the degree of fractional crystallization.

\section{PETROGRAPHY}

Basaltic rocks recovered in Hole 396B are either glassy to fine-grained pillow lava or fine to medium-grained massive lava. The textural features of groundmass of pillows are similar among all the pillow lavas of Hole 396B. A massive lava of lithologic Unit 2 exhibits systematic textural and grain-size variations of groundmass against the depth of the core specimen. In the following section, textural and grainsize variations of the groundmass of these pillow and massive lavas are described first. Then, other petrographic features (such as mode, grain-size distribution, and textures of phenocrysts) are described for each chemical unit.

\section{Groundmass}

\section{Pillow Lava}

The size of pillow is 40 to $80 \mathrm{~cm}$ in diameter, as deduced from the complete section of pillows obtained in Section 20-1. Each pillow is divided into four zones according to the texture of groundmass. From the rim to the interior, they are sideromelane glass zone, cryptocrystalline variolite zone, microcrystalline spherulite zone, and intersertal interior zone. The textural features of these zones are summarized in Table 1. All the sideromelane glass zone of Hole 396B pillows contain minute skeletal olivine and thin fork-shaped plagioclase crystals, indicating that olivine and plagioclase are the near-liquidus phases of these basaltic magmas. Crystallinity increases rapidly from the variolite zone to the spherulite zone, and the primary constituents of the interior of the pillows are olivine, clinopyroxene, plagioclase, titanomagnetite, and mesostasis. The alteration products are palagonite after sideromelane glass, $\mathrm{Fe}-\mathrm{Mn}$ oxides and hydro-oxides, smectites, mica, zeolites, and carbonates.

Vesicles are found throughout the pillows. Most of vesicles are spherical and their diameter ranges from 0.1 to 1 $\mathrm{mm}$. Vesicle contents are 0 to 5 per cent. The low vesicle contents are indicative of the greater water depth (more than $1000 \mathrm{~m}$ ) of the formation of pillows (Moore and Schilling, 1973). Some of the vesicles are filled by either residual material similar to the intersticies of groundmass (Sato, this volume) or by smectite, zeolite, or carbonate.

\section{Massive Lava}

The textural features and the grain size of the groundmass constituents of the massive lava are shown in Table 2. The unit can be divided into three zones according to the groundmass texture; the upper (235.92 to $238.75 \mathrm{~m}$ subbottom depth), the middle ( 238.78 to $240.32 \mathrm{~m}$ ), and the lower zones ( 240.34 to $242.00 \mathrm{~m}$ ). Within the upper zone, groundmass texture varies from intersertal to intergranular, and the grain size of every primary constituent mineral increases downwards. The middle zone of the lava unit is characterized by patchy structure. Fine-grained variolitic patches, average diameter of $5 \mathrm{~mm}$ and constituting onethird to one-half of the rock, are surrounded by coarsegrained intergranular part. The intergranular part consists mainly of thick plagioclase laths and stout idiomorphic crystals of olivine and clinopyroxene, while the variolitic patch is mainly composed of feather-like or dendritic crystals of clinopyroxene with interstitial minute plagioclase laths and opaque minerals. The width of clinopyroxene and plagioclase of the patch increases downwards within the middle zone, leading to the gradual disappearance of the patchy structure from the middle to the lower zones. Through the massive lava unit, olivine and plagioclase show simple grain size variation; they attain maximum size in the middle zone, suggesting that the unit is a single cooling unit. The presence of fine-grained patches in the middle zone may be interpreted as the result of either an increased cooling rate at the advanced stage of crystallization of the lava caused by the penetration of water through cracks, or 


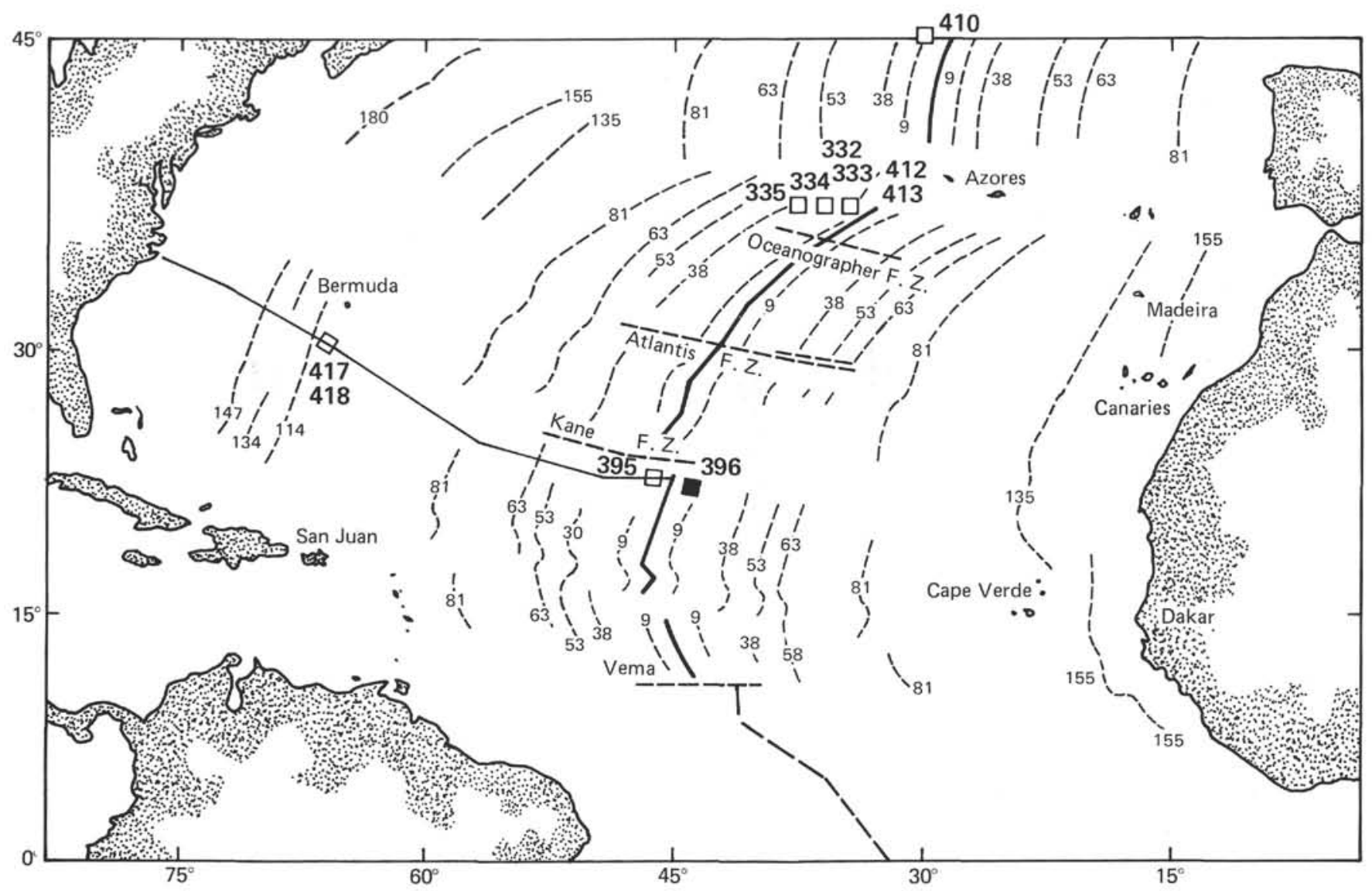

Figure 1. Location of Hole 396, IPOD/DSDP Leg 46 in the Atlantic Ocean. Dashed lines are the magnetic anomaly lineaments, the attached number denotes the age of their formation in m.y. B.P.

two crystallization stages during simple cooling of a lava caused by the supercooling effect as demonstrated for lunar basalt (Dowty et al., 1974; Walker et al., 1976).

\section{Phenocryst}

Subunit A $A_{1}$ : Chemical Subunit $\mathrm{A}_{1}(150.5$ to $178.5 \mathrm{~m})$ consists of pillow lavas of sparsely-phyric basalt. Phenocrysts constitute less than 1 volume per cent of the rock, and are composed of olivine and plagioclase. The grain size of all the phenocrysts in thin sections of Subunit $\mathrm{A}_{1}$ basalts is shown in Figure 3. The grain size represents the geometric mean diameter of each crystal at thin-section surface, and the frequency of occurrence is summed for each logarithmic scale interval of the factor of 1.5. The deviation of these apparent size distributions from the true size distribution is very small (about $75 \%$ of the apparent diameter fall within two-thirds of the true diameter). Figure 3 illustrates that olivine phenocryst is much more abundant than plagioclase phenocryst in Subunit $A_{1}$. The grain size of olivine phenocrysts ranges from 0.1 to $2.5 \mathrm{~mm}$ and its mode is 0.2 $\mathrm{mm}$. Larger olivine phenocryst tends to be corroded, while some of the smaller olivine phenocryst show skeletal texture. Plagioclase phenocrysts are either rounded or tabular idiomorphic. The rounded plagioclase phenocryst displays fine polysynthetic albite twinning. Plagioclase phenocrysts of Subunit $A_{1}$ show little zoning.
Subunit $\mathbf{A}_{2}$ : Mineral assemblage and the mode of occurrences of phenocrysts in chemical Subunit $A_{2}$ are similar to those in chemical Subunit $A_{1}$ except for much more frequent occurrence of large and corroded phenocrysts of both olivine and plagioclase (Figure 3).

Subunit $\mathbf{A}_{3}$ : Chemical Subunit $A_{3}$ is also composed of sparsely phyric basalt, but has slightly different phenocryst occurrences than $A_{1}$ and $A_{2}$ (Figure 3 ). Olivine phenocryst is idiomorphic and occurs only in one sample (in Core 14). Rounded plagioclase phenocrysts have calcic cores with a sharply defined sodic rim. A Ca-rich clinopyroxeneplagioclase crystal clot, $15 \mathrm{~mm}$ by $8 \mathrm{~mm}$ in size, was found in Sample 15-5, 70-77 cm (Plate 1); this is the only clinopyroxene phenocryst found to date in Hole 396B. The clot shows ophitic texture; a few large clinopyroxene crystals ( 3 to $10 \mathrm{~mm}$ ) contain smaller plagioclase laths ( 1 to 3 $\mathrm{mm}$ long). Clinopyroxene occupies 66 volume per cent of the clot. Clinopyroxene is evidently corroded against groundmass. Tabular plagioclase lath projects into groundmass, in which it is slightly rounded and has a sharp reverse-zoned rim (Plate 1). The projection of plagioclase crystal from the clot indicates the selective corrosion of clinopyroxene phenocryst. Plagioclase within the clot exhibits slight concentric and sector zoning. Along the boundary with clinopyroxene, plagioclase has minute fluid inclusions and a calcic rim. 


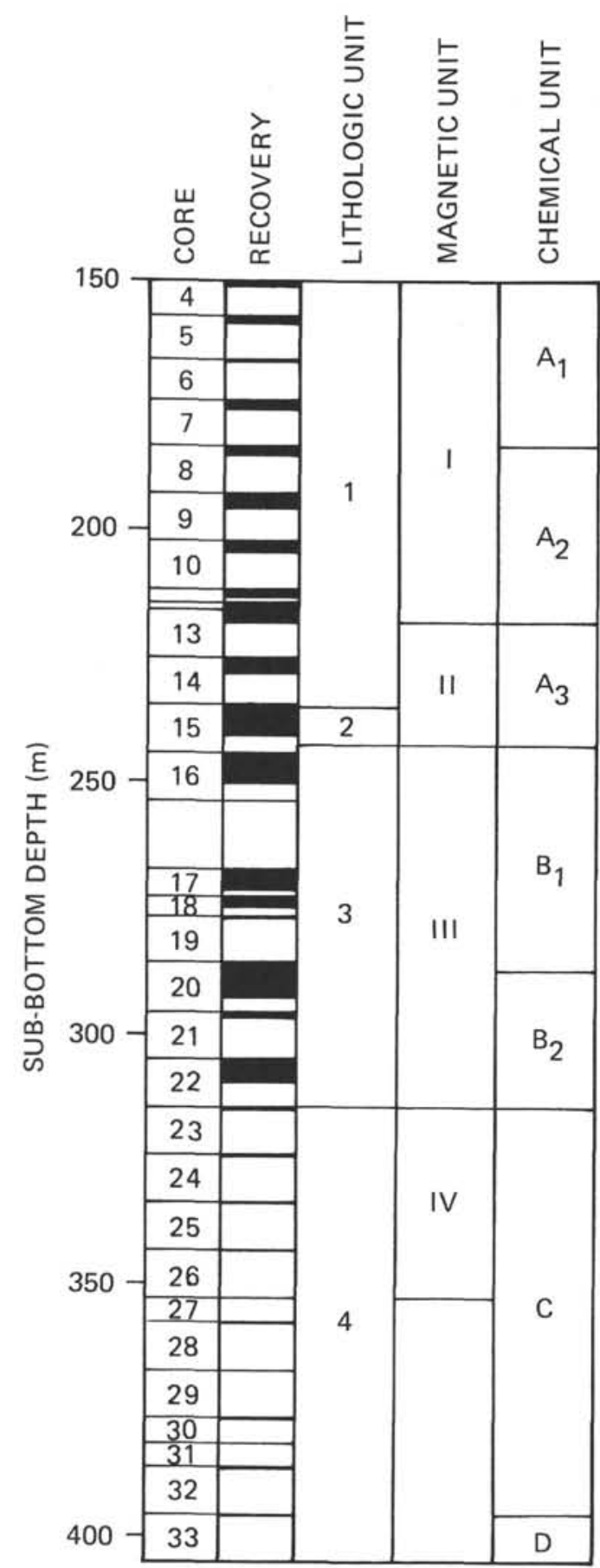

Figure 2. Stratigraphic division of the basaltic basement of Hole $396 B$.

Subunit $\mathbf{B}_{1}$ : This subunit is composed of pillow lava of phyric basalt, containing phenocrysts of plagioclase, olivine, and chromian spinel. Mode of phenocrysts in phyric basalt of Subunit $B_{1}$ is presented in Table 3 and plagioclase-olivine-matrix ratios are plotted in Figure 4. The total phenocryst content of Subunit $B_{1}$ is 15 to 20 volume per cent, and the plagioclase/olivine modal ratio is about 6 . Mode of chromian spinel phenocryst averages 0.02 per cent. Grain-size distributions of these phenocrysts are shown in Figures 5 and 6. All of these phenocrysts show unimodal grain size distribution; hence, there is no reason to separate phenocryst from microphenocryst for these phyric basalts of Hole 396B, though some of the ocean-floor basalt may display bimodal grain-size distribution for phenocrysts (Shido et al., 1973). Most of the olivine phenocrysts in Subunit $\mathrm{B}_{1}$ are idiomorphic. Glomerophyric crystal aggregates of olivine and plagioclase, up to $7 \mathrm{~mm}$ in diameter, are found occasionally. The aggregate consists of 1 or 2 large olivine crystals and abundant smaller plagioclase laths showing ophitic texture. Olivine phenocryst often contains matrix, plagioclase, and chromian spinel as inclusions. Plagioclase phenocryst is tabular idiomorphic or rounded, or skeletal. Sometimes, a large plagioclase phenocryst is a composite grain. Matrix inclusion occupies an average of 2 per cent of host plagioclase, but it sometimes occupies up to 50 per cent. Matrix inclusions occur only in the core of the plagioclase phenocryst, or only in the marginal zone, or evenly throughout the crystal. Plagioclase phenocryst with abundant matrix inclusion tends to be skeletal, and often develops fine polysynthetic albite twinning. Some of the tabular plagioclase phenocrysts show sector zoning. Chromian spinel occurs as inclusions in olivine or plagioclase, or as isolated grains in groundmass. It is euhedral, or rounded, or skeletal, and is 10 to $660 \mu \mathrm{m}$ in diameter (Figure 5). The color of chromian spinel varies from brown to reddish brown to dark red.

Subunit $\mathbf{B}_{2}$ : Mineral assemblage and the mode of occurrences of phenocryst in chemical Subunit $\mathrm{B}_{2}$ are similar to those in chemical Subunit $B_{1}$, except for the slightly higher content of phenocrysts olivine and plagioclase (Figure 4).

Unit C: Chemical Unit $\mathrm{C}$ is composed of variable basaltic clastic rocks, such as basaltic sand and sandstone, hyaloclastite, and pillow breccia. They are sparsely phyric basalt containing 1 to 3 per cent of phenocryst of olivine and plagioclase. Pillow fragments of Unit $\mathrm{C}$ are characterized by larger varioles $(0.5$ to $1.0 \mathrm{~mm}$ in diameter $)$ in the groundmass than those of Units A and B (the size of varioles is 0.1 to $0.3 \mathrm{~mm}$ ).

Unit D: Chemical Unit D is also composed of basaltic clastic rocks. The petrographical feature of basalt of Unit D, however, varies from sparsely phyric basalt (total phenocryst content $<1 \%$ ) to phyric olivine-plagioclase basalt (total phenocryst content up to $15 \%$ ).

\section{MINERAL CHEMISTRY}

\section{Olivine}

The chemical composition of olivine is shown in Table 4 and Figures 7, 8, 9, and 10. The following three types of chemical zoning of olivine are recognized: (1) normal zoning of phenocryst core, (2) reverse zoning of phenocryst core, and (3) normal zoning of phenocryst rim and groundmass. In normal zoning of the phenocryst core (Type 1), the homogeneous $\mathrm{Mg}$-rich inner zone ( $\mathrm{Fo}=$ forsterite content up to $89 \%$ ) is surrounded by an Fe-increasing marginal zone (Figure $7[b]$ ). Reverse zoning (Type 2) has a homogeneous Fe-rich inner zone (Fo, $83 \%$ ) surrounded by a $\mathrm{Mg}$-increasing marginal zone (Figure 7 [a]). The compositional range of zoned core of the olivine phenocryst (Types 1 and 2) is up to 3 mole per cent in Fo content (Figures 7 and 
TABLE 1

Zonal Variation of Textures of Pillow in Hole 396B

\begin{tabular}{|c|c|c|c|}
\hline & Zone & $\begin{array}{l}\text { Thickness } \\
\text { (mm) }\end{array}$ & Primary Constituents \\
\hline I & $\begin{array}{l}\text { Sideromelane } \\
\text { glass zone }\end{array}$ & $\begin{array}{l}\text { avg. } 8 \\
(3-16)\end{array}$ & $\begin{array}{l}\text { glass }(>99 \%) \text { : palagonitized at surface or along cracks }(1-2 \mathrm{~mm} \text {, thick }) \\
\text { plagioclase }(<1 \%) \text { : hopper }(0.1 \times 0.01 \mathrm{~mm}) \\
\text { olivine }(<1 \%) \text { : skeletal }(0.01-0.03 \mathrm{~mm}) \\
\text { sulfides }(\ll 1 \%) \text { : rounded, irregular, or lining in vesicles }(0.001-0.02 \mathrm{~mm})\end{array}$ \\
\hline II & $\begin{array}{l}\text { Cryptocrystalline } \\
\text { variolite zone }\end{array}$ & $\begin{array}{l}\text { avg. } 8 \\
(4-12)\end{array}$ & $\begin{array}{l}\text { variole }(>99 \%) \text { : cryptocrystalline, occasionally with incipient retardation } \\
\text { plagioclase }(<1 \%) \text { : hopper }(\ell=0.1 \mathrm{~mm}) \\
\text { olivine }(<1 \%) \text { : skeletal }(0.02-0.05 \mathrm{~mm}) \\
\text { sulfides }(\varangle 1 \%) \text { : rounded or irregular }(0.001-0.02 \mathrm{~mm})\end{array}$ \\
\hline III & $\begin{array}{l}\text { Microcrystalline } \\
\text { spherulite zone }\end{array}$ & $10-30$ & $\begin{array}{l}\text { plagioclase }(10-50 \%) \text { : hopper, radially arranged forming the spherulitic } \\
\text { texture with clinopyroxene }(0.1-0.2 \mathrm{~mm}) \\
\text { olivine }(\sim 3 \%) \text { : skeletal, euhedral }(0.03-0.1 \mathrm{~mm}) \\
\text { clinopyroxene }(0-40 \%) \text { : variolitic, very fine } \\
\text { sulfide }(\ll 1 \%) \text { : rounded or irregular }(0.001-0.02 \mathrm{~mm}) \\
\text { titanomagnetite: very fine, dusty }\end{array}$ \\
\hline IV & $\begin{array}{l}\text { Intersertal } \\
\text { interior zone }\end{array}$ & $500-1000$ & $\begin{array}{l}\text { plagioclase }(40-60 \%) \text { : dense hopper, random orientation }(0.1-0.5 \mathrm{~mm}) \\
\text { olivine }(1-5 \%) \text { : euhedral, skeletal }(0.05-0.1 \mathrm{~mm}) \\
\text { clinopyroxene }(40-50 \%) \text { : variolitic, dendritic in the intersiticies } \\
\text { sulfide }(\$ 1 \%): \text { rounded or irregular }(0.001-0.02 \mathrm{~mm}) \\
\text { titanomagnetite }(1-5 \%) \text { : cube or skeletal }(0.001-0.01 \mathrm{~mm})\end{array}$ \\
\hline
\end{tabular}

8). Olivine phenocrysts with Types 1 or 2 zoning occur in pillow margin, indicating that they were formed in the intratelluric stage of crystallization. They co-exist in one specimen. The rims of these olivine phenocrysts have the same Fo content (Figure 8). Type 3 normal zoning of olivine is only observed in the well-crystallized interior of pillows and in the massive lava. It is observed only at the narrow periphery of olivine phenocryst (Figure 7 [a]), suggesting that diffusion homogenization after the extrusion of magma (Moore and Evans, 1967) is minimal in the olivine of pillow lava.

The compositional variation of olivine in relation to the stratigraphic units is shown in Figure 9. The analyses were carried out on the rim of olivine crystal. For each chemical unit, mean olivine composition is nearly constant. Forsterite content of the analyzed olivine is well correlated with the $\mathrm{Mg} /(\mathrm{Mg}+\mathrm{Fe})$ ratio of the host glass. Supposing the oxidation index $\left(\mathrm{OX}=\mathrm{Fe}^{3+} /\right.$ total $\left.\mathrm{Fe}\right)$ of 0.1 , we calculated $\mathrm{Mg}$-Fe partition coefficient between olivine and glass for each unit. The partition coefficient is nearly constant and the average value is 0.285 which is in close agreement with the equilibrium experimental value of Roeder and Emslie (1970) (0.30). Thus, the olivine and glass may have retained the equilibrium partition relation at the time of extrusion. Among trace elements of olivine, nickel is of particular interest in evaluating the role of olivine in the fractional crystallization of basaltic magmas (Sato, 1977). As is shown in Figure 10, olivines of sparsely phyric (chemical Subunits $A_{1}$ and $\left.A_{2}\right)$ and phyric $\left(B_{1}\right.$ and $\left.B_{2}\right)$ basalts show a little different trends in the $\mathrm{NiO}$ versus forsterite content diagram. Olivine in phyric basalt is more $\mathrm{Mg}$-rich than that in sparsely phyric basalt for the same $\mathrm{NiO}$ content. Both trends show positive correlation between the forsterite and $\mathrm{NiO}$ contents, and are nearly parallel to the curve of the model fractional crystallization trend of olivine (Figure 10).

\section{Ca-rich Clinopyroxene}

The only one Ca-rich clinopyroxene phenocryst in the drilled basalt of Holes 396 and 396B occurs as crystal clot in the lower portion of the massive lava of chemical Subunit $\mathrm{A}_{3}$. Chemical compositions of minerals of both the crystal clot and the surrounding groundmass are shown in Table 5, and are plotted in Figures 11 through 14. Clinopyroxene of the clot is rather homogeneous with $\mathrm{Ca}_{36-40} \mathrm{Mg}_{50-53} \mathrm{Fe}_{10-11}$ and is distinct from the groundmass clinopyroxene (Figure 11). $\mathrm{The} \mathrm{Mg} /(\mathrm{Mg}+\mathrm{Fe})$ ratio of the clot clinopyroxene is 0.83 , while that of the groundmass clinopyroxene is 0.74 to 0.65 . The clot clinopyroxene is much lower in $\mathrm{Ti}, \mathrm{Al}$, and $\mathrm{Na}$ contents as well as in $\mathrm{Ti} / \mathrm{Al}$ ratio than those in the groundmass (Figures 13 and 14). The difference of chemistry between the clot and the groundmass clinopyroxenes suggests a discontinuous crystallization history of clinopyroxene. $\mathrm{Mg} /(\mathrm{Mg}+\mathrm{Fe})$ ratio of the clot clinopyroxene is similar to that of the groundmass olivine, and it is considered that clot clinopyroxene was in close partition equilibrium with the host magma. One atmosphere fusion experiment (Fukuyama and Hamuro, this volume) shows that $\mathrm{Ca}$ rich clinopyroxene is unstable at the liquidus temperature of basalt of chemical Subunit $A_{3}$. The corrosion of the clot clinopyroxene may have taken place at shallow depth before the extrusion of the magma. Kushiro (1973) has shown that the stability of Ca-rich clinopyroxene increases with increasing pressure, and clinopyroxene appears as a liquidus phase above 7 to 8 kilobars for ocean-floor olivine tholeiite. It is conceivable that the clinopyroxene crystal clot in Subunit $\mathrm{A}_{3}$ of Hole 396B represents relatively high-pressure phenocryst when compared with most of the other euhedral phenocrysts of olivine and plagioclase. The sodic nature of the clot plagioclase $(\mathrm{Ca} /[\mathrm{Ca}+\mathrm{Na}] \cong 0.64)$ may be interpreted by the shift of partition equilibrium due to pressure.

\section{Plagioclase}

Representative chemical analyses of plagioclase are shown in Table 6, and they are plotted in Figures 15 through 20. The plotted data include the partial analyses of plagioclase in which only $\mathrm{Na}$ and $\mathrm{Ca}$ are analyzed. The standard error of the obtained $\mathrm{Ca} /(\mathrm{Ca}+\mathrm{Na})$ ratio of partial 
TABLE 2

Grain Size of Groundmass Constituents of the Massive Lava $(\mu)$

\begin{tabular}{|c|c|c|c|c|c|c|c|c|c|c|c|c|c|c|}
\hline \multirow{2}{*}{$\begin{array}{l}\text { Massive lava } \\
\text { Sub-zone }\end{array}$} & \multirow{2}{*}{ Sample } & \multirow{2}{*}{$\begin{array}{l}\text { Depth } \\
\text { (m) }\end{array}$} & \multirow{2}{*}{ Texture } & \multirow{2}{*}{\multicolumn{2}{|c|}{ Olivine }} & \multicolumn{2}{|c|}{$\begin{array}{l}\text { Plagioclase } \\
\text { (1) }\end{array}$} & \multirow{2}{*}{$\begin{array}{l}\text { Plagioclase } \\
\text { (2) } \\
\text { light } \\
\text { dark }\end{array}$} & \multirow{2}{*}{ Granulitic } & \multicolumn{3}{|c|}{ Clinopyroxene } & \multirow{2}{*}{$\begin{array}{l}\text { Ilmenite } \\
\text { (d) }\end{array}$} & \multirow{2}{*}{$\begin{array}{l}\text { Sulfide } \\
(f)\end{array}$} \\
\hline & & & & & & light & $\sigma$ & & & Yeriolitina & & Mesostasis & & \\
\hline \multirow[t]{4}{*}{ Upper } & $15-1,6$ & 135.4 & glass variolitic & 57 & 17 & 142 & 63 & - & - & - & - & - & - & $1-2$ \\
\hline & $15-1,12$ & 135.95 & intersertal & 50 & 15 & $\begin{array}{r}13 \\
667 \\
49\end{array}$ & $\begin{array}{r}7 \\
322 \\
7\end{array}$ & - & - & - & $2-6$ & $1-4$ & n.d. ${ }^{b}$ & n.d. \\
\hline & $51-2,2(B)$ & 237.55 & intergranular & 86 & 18 & $\begin{array}{r}1345 \\
122\end{array}$ & $\begin{array}{r}633 \\
40\end{array}$ & $=$ & $30-120$ & - & - & $5-20$ & $1-3$ & $2-10$ \\
\hline & $15-3,2(B)$ & 238.20 & intergranular & 149 & 99 & $\begin{array}{r}1070 \\
209\end{array}$ & $\begin{array}{l}575 \\
119\end{array}$ & - & $30-150$ & $30-150$ & - & $S-20$ & $1-3$ & $2-10$ \\
\hline \multirow[t]{4}{*}{ Middle } & $15-3,3(\mathrm{~A})$ & 238.80 & $\begin{array}{c}\text { intergranular } \\
\text {-variolitic }\end{array}$ & 115 & 23 & $\begin{array}{r}1356 \\
149\end{array}$ & $\begin{array}{r}899 \\
34\end{array}$ & $\begin{array}{c}30-100 \\
5-30\end{array}$ & $30-100$ & $\begin{array}{c}30-100 G \\
5-20 \quad P\end{array}$ & - & $3-15$ & $1-2$ & $1-6$ \\
\hline & $15-3,7$ & 239.35 & $\begin{array}{l}\text { intergranular } \\
\text {-variolitic }\end{array}$ & 134 & 38 & $\begin{array}{r}1789 \\
297\end{array}$ & $\begin{array}{l}782 \\
110\end{array}$ & $\begin{array}{l}80-200 \\
10-50\end{array}$ & $30-150$ & $\begin{array}{l}30-150 \mathrm{C} \\
10-30 \quad \mathrm{P}\end{array}$ & - & $5-10$ & $1-2$ & $2-15$ \\
\hline & $15-4,2(\mathrm{C})$ & 239.90 & $\begin{array}{l}\text { intergranular } \\
\text {-variolitic }\end{array}$ & 103 & 28 & $\begin{array}{r}1193 \\
192\end{array}$ & $\begin{array}{r}472 \\
85\end{array}$ & $\begin{array}{l}80-200 \\
10-40\end{array}$ & $30-150$ & $\begin{array}{l}30-150 \mathrm{G} \\
10-40 \quad \mathrm{P}\end{array}$ & - & $3-10$ & $1-3$ & $2-10$ \\
\hline & $15-4,4$ & 240.20 & $\begin{array}{l}\text { intergranular } \\
\text {-variolitic }\end{array}$ & 173 & 118 & $\begin{array}{r}1317 \\
190\end{array}$ & $\begin{array}{r}706 \\
66\end{array}$ & $\begin{array}{c}100-400 \\
10-80\end{array}$ & $30-150$ & $\begin{array}{l}30-150 \mathrm{G} \\
20-40 \mathrm{P}\end{array}$ & - & $5-30$ & $1-2$ & $2-10$ \\
\hline \multirow[t]{3}{*}{ Lower } & $15-4,7(\mathrm{~A})$ & 240.65 & intergranular & 97 & 20 & $\begin{array}{r}495 \\
77\end{array}$ & $\begin{array}{r}299 \\
20\end{array}$ & - & $20-80$ & $20-80$ & - & $4-10$ & $1-3$ & $2-5$ \\
\hline & $15-5,3$ & 241.30 & intersertal & 65 & 10 & $\begin{array}{r}346 \\
45\end{array}$ & $\begin{array}{r}168 \\
18\end{array}$ & - & - & - & $3-10$ & $1-3$ & n.d. & n.d. \\
\hline & $15-5,9$ & 241.75 & intersertal & 57 & 13 & $\begin{array}{r}330 \\
52\end{array}$ & $\begin{array}{r}125 \\
17\end{array}$ & - & - & - & $3-10$ & $1-3$ & n.d. & n.d. \\
\hline
\end{tabular}
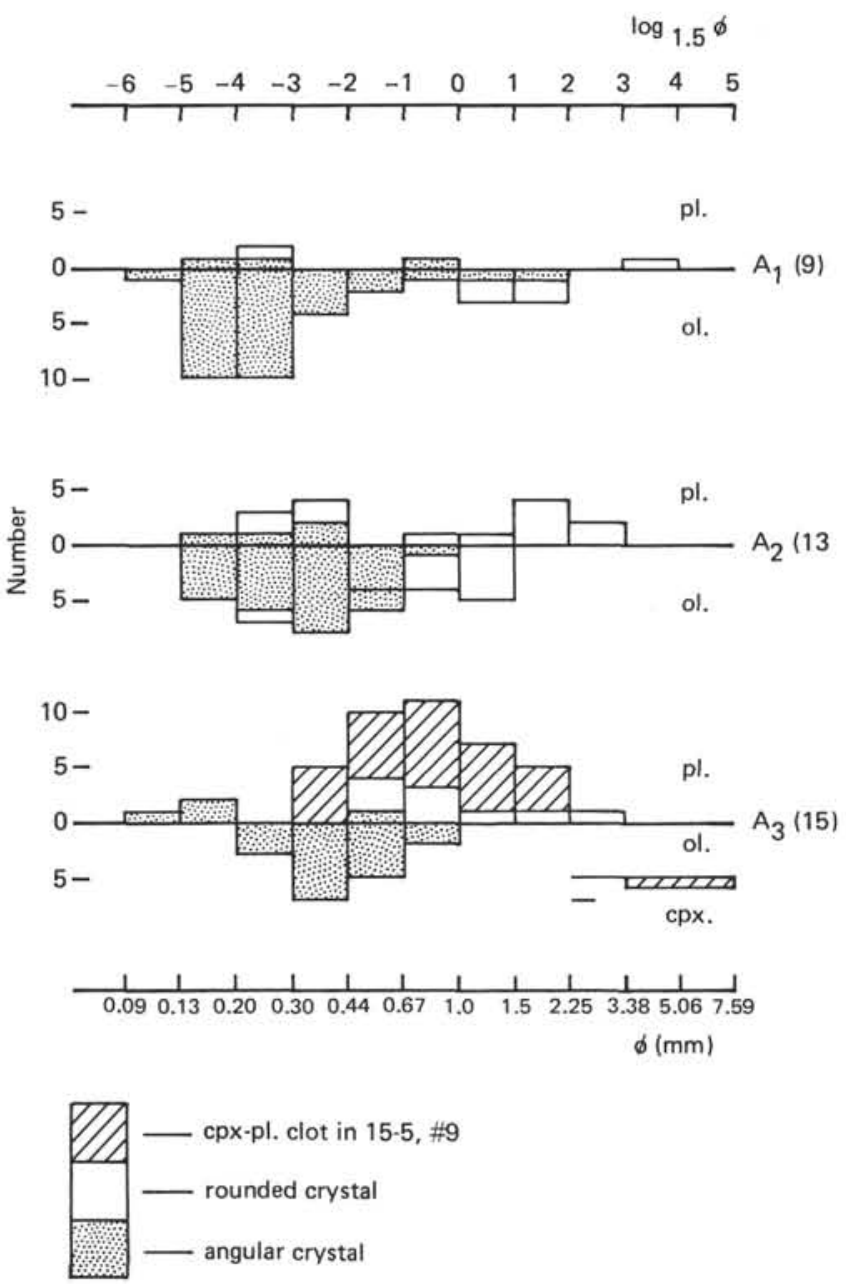

Figure 3. Mode of occurrence of phenocryst in the sparsely phyritic basalt of chemical Units $A_{1}, A_{2}$, and $A_{3}$. analyses is about 0.005 . Plagioclase phenocrysts in the phyric basalt usually show normal zoning at the margin. Calcic core is surrounded by a broad sodic inner rim, which is then surrounded by a more sodic outer rim. The inner rim is 50 to $300 \mu \mathrm{m}$ thick and is homogeneous. The boundaries between the core and the inner rim and between the inner and the outer rims are sharp. The core of the plagioclase phenocryst in phyric basalt is either euhedral or rounded and shows variable zoning pattern, flat, oscillatory, gradual normal and reverse, sharp normal and reverse, patchy, and other complex zoning. It is difficult to find regularity of the core zoning pattern among plagioclase phenocrysts in a rock specimen. Figures 15 through 18 illustrate the compositional range of plagioclase phenocrysts for phyric basalts. Compositional range of the core is read from the continuous scanning profiles of phenocryst grains on which several partial analyses are made for calibration. Scanning profiles on 15 to 23 grains are taken for each sample. These figures show that the compositional range of the core differs from grain to grain in a sample, irrespective of the grain size. The $\mathrm{Ca} /(\mathrm{Ca}+\mathrm{Na})$ ratio of the core of plagioclase phenocryst ranges from 0.72 to 0.89 . The composition of the inner rim of phenocryst is 0.70 to 0.75 . The occurrence of the inner rim of plagioclase phenocryst does not depend on the crystallinity of groundmass of pillow lava, indicating that the inner rim was formed before the eruption of magma on the sea floor. The outer thin rim of plagioclase phenocryst is absent in the outer sideromelane and variolite zones of pillow lava, and occurs only in its interior. The compositional range of the outer rim of plagioclase phenocryst coincides with that of groundmass plagioclase core (Figures 15 through 18 and 20), showing that the outer rim has grown after the eruption of magmas.

The stratigraphic variations of the composition of both phenocryst and groundmass plagigclases are shown in Figures 19 and 20 , respectively. The compositional range of 
TABLE 3

Modal Compositions of Phyric Basalt of Hole 396B, Leg 46

\begin{tabular}{|c|c|c|c|c|c|c|c|c|c|c|}
\hline \multirow[b]{2}{*}{$\begin{array}{c}\text { Sample } \\
\text { (Interval in } \mathrm{cm} \text { ) }\end{array}$} & \multirow[b]{2}{*}{ Piece No. } & \multicolumn{5}{|c|}{ Phenocryst } & \multirow[b]{2}{*}{ Groundmass } & \multirow[b]{2}{*}{ Vesicle } & \multirow[b]{2}{*}{ Vein } & \multirow[b]{2}{*}{ Point } \\
\hline & & Olivine & $\begin{array}{l}\text { Inclusion } \\
\text { in Olivine }\end{array}$ & Plagioclase & $\begin{array}{c}\text { Inclusion } \\
\text { in Plagioclase }\end{array}$ & Spinel & & & & \\
\hline $16-2, \quad 35-44$ & \# 4(A) & 4.26 & 0.00 & 15.66 & 0.47 & 0.00 & 79.23 & 0.38 & 0.00 & 3404 \\
\hline $16-2,124-132$ & \#11(A) & 1.27 & 0.00 & 15.20 & 0.12 & 0.00 & 82.24 & 1.16 & 0.00 & 8159 \\
\hline $16-3,131-137$ & \#15 & 1.92 & 0.00 & 14.30 & 0.13 & 0.00 & 82.66 & 0.96 & 0.00 & 3022 \\
\hline $17-1, \quad 19-25$ & \#2(A) & 3.55 & 0.00 & 15.23 & 0.23 & 0.03 & 80.16 & 0.81 & 0.00 & 3552 \\
\hline $17-1,131-137$ & \#11(B) & 3.42 & 0.11 & 13.57 & 0.28 & 0.00 & 82.11 & 0.50 & 0.00 & 3567 \\
\hline $17-2, \quad 17-25$ & $\# 2(\mathrm{~A})$ & 2.50 & 0.05 & 14.66 & 0.23 & 0.01 & 81.95 & 0.96 & 0.00 & 10533 \\
\hline $18-1,132-141$ & $\# 7(\mathrm{~F})$ & 6.89 & 0.06 & 13.51 & 0.42 & 0.00 & 78.73 & 0.38 & 0.00 & 3084 \\
\hline $18-2,80-88$ & $\# 4$ & 2.35 & 0.00 & 14.87 & 0.43 & 0.00 & 81.68 & 0.67 & 0.00 & 2555 \\
\hline $19-1, \quad 4-11$ & \# 1 & 2.21 & 0.00 & 14.15 & 0.07 & 0.00 & 83.22 & 0.35 & 0.00 & 2890 \\
\hline $20-1, \quad 82-90$ & $\# 4(F)$ & 1.98 & 0.00 & 17.22 & 0.27 & 0.00 & 79.50 & 1.02 & 0.00 & 6308 \\
\hline $20-1, \quad 95-102$ & \# 4(G) & 2.10 & 0.00 & 16.40 & 0.00 & 0.00 & 80.40 & 1.09 & 0.00 & 2561 \\
\hline $20-1,114-122$ & \# 4(I) & 2.38 & 0.11 & 15.30 & 0.42 & 0.00 & 79.29 & 1.98 & 0.50 & 3574 \\
\hline $20-1,122-126$ & $\# 4(\mathrm{~J})$ & 2.91 & 0.05 & 13.65 & 0.79 & 0.00 & 79.96 & 1.26 & 1.39 & 3818 \\
\hline $20-2, \quad 4-10$ & $\# 1$ & 1.71 & 0.00 & 14.07 & 0.22 & 0.00 & 83.19 & 0.81 & 0.00 & 3213 \\
\hline $20-2, \quad 37-45$ & \# 4 & 3.38 & 0.03 & 18.15 & 0.29 & 0.07 & 76.71 & 1.37 & 0.00 & 3074 \\
\hline $20-2,136-141$ & $\# 9(\mathrm{G})$ & 2.85 & 0.05 & 13.30 & 0.22 & 0.00 & 83.14 & 0.44 & 0.00 & 3653 \\
\hline $20-3, \quad 20-28$ & $\# 3$ & 3.72 & 0.04 & 18.63 & 0.56 & 0.00 & 75.85 & 1.19 & 0.00 & 4460 \\
\hline $20-4, \quad 69-75$ & $\# 11(\mathrm{~A})$ & 3.40 & 0.00 & 19.34 & 0.35 & 0.00 & 75.52 & 1.39 & 0.00 & 3739 \\
\hline $20-6, \quad 44-53$ & $\# 6$ & 3.43 & 0.05 & 21.32 & 0.69 & 0.00 & 72.95 & 1.54 & 0.00 & 4193 \\
\hline $21-1, \quad 70-89$ & \# 9 & 4.63 & 0.09 & 20.23 & 0.42 & 0.03 & 73.14 & 1.88 & 0.00 & 3347 \\
\hline $21-2, \quad 43-50$ & \# 4 & 5.93 & 0.08 & 16.02 & 0.35 & 0.00 & 77.50 & 0.12 & 0.00 & 2565 \\
\hline $22-1,105-121$ & $\# 13$ & 2.20 & 0.00 & 17.96 & 0.10 & 0.00 & 79.13 & 0.60 & 0.00 & 3819 \\
\hline $22-2,125-145$ & $\# 70$ & 1.79 & 0.03 & 18.81 & 0.39 & 0.05 & 78.70 & 0.24 & 0.00 & 3850 \\
\hline Average & & & & & & & & & & \\
\hline
\end{tabular}

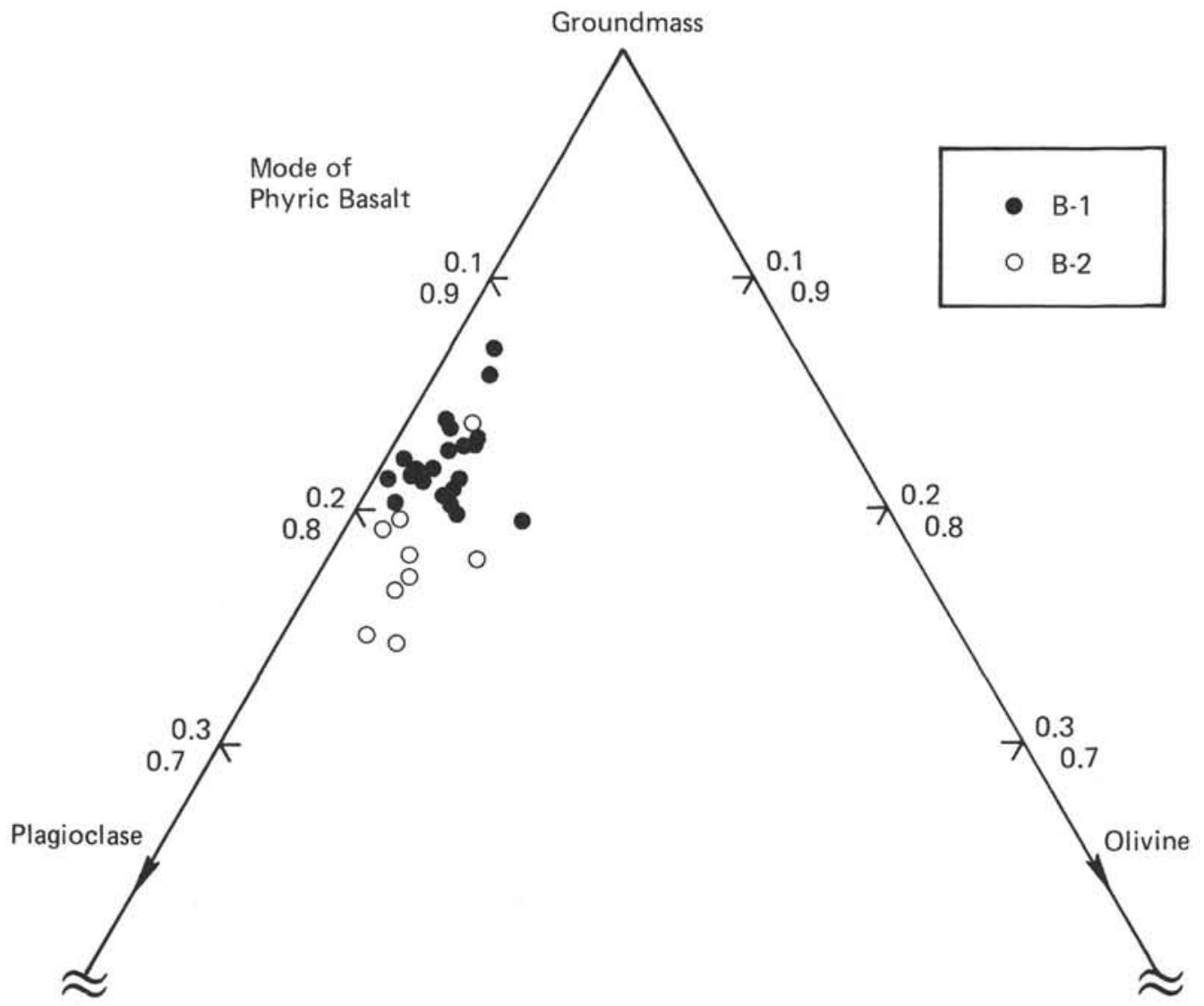

Figure 4. Modal ratio groundmass-phenocryst olivine-phenocryst plagioclase of phyric basalts of chemical Units $B_{1}$ and $B_{2}$. 


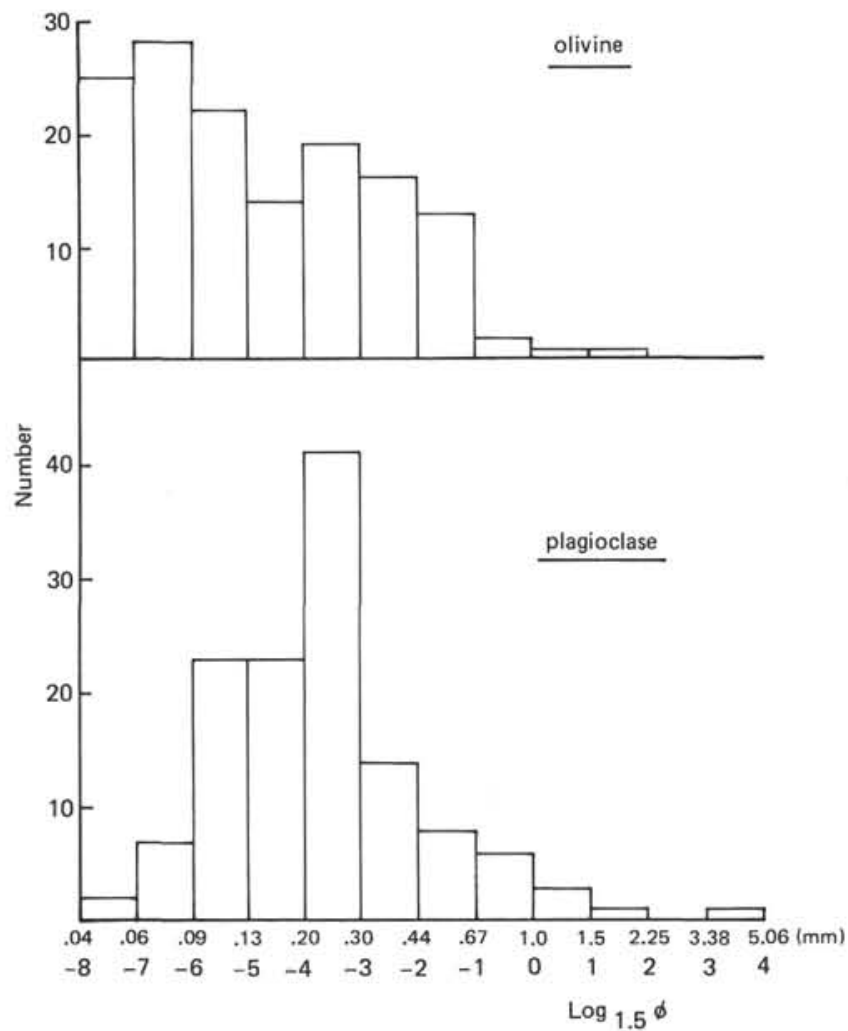

Figure 5. Grain-size distribution of phenocryst olivine and plagioclase in phyric basalts.

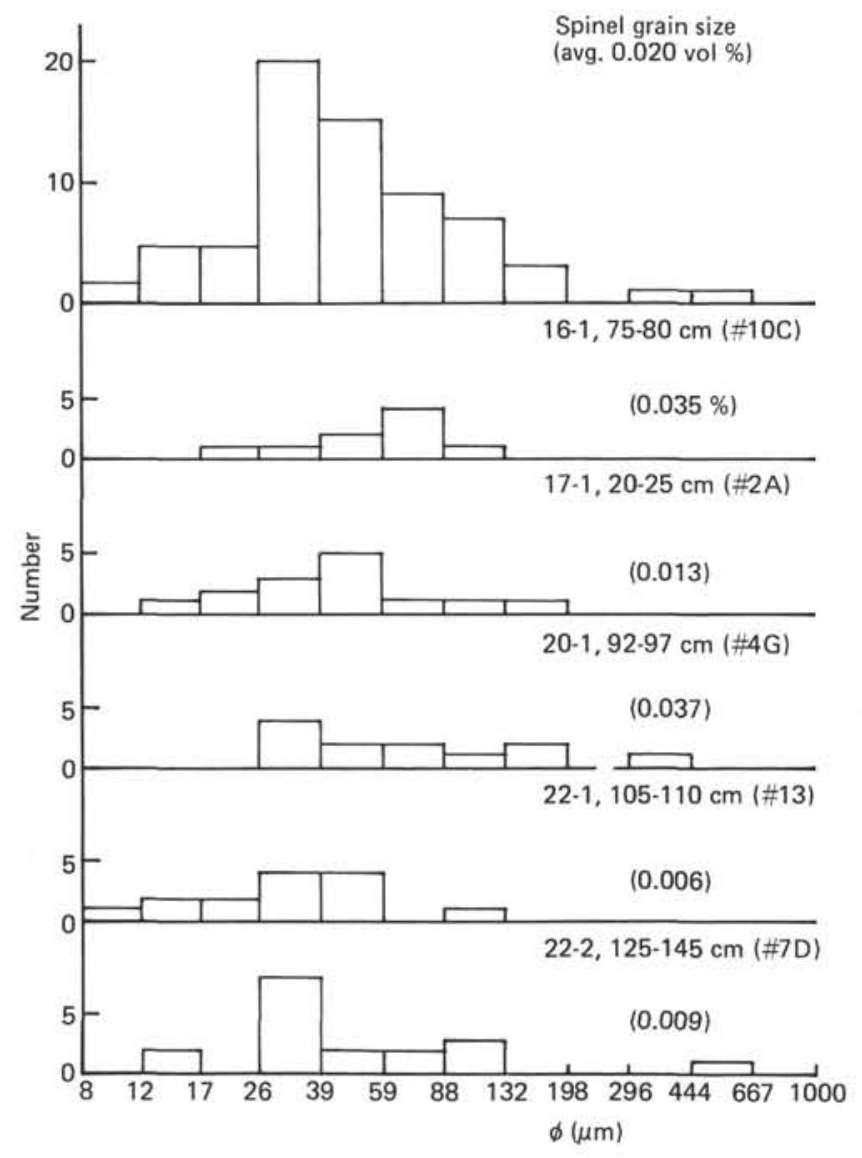

Figure 6. Grain-size distribution of phenocryst spinel in phyric basalts. the phenocryst core is nearly constant among analyzed phyric basalts of Subunits $B_{1}$ and $B_{2}$. Plagioclase phenocrysts in the sparsely phyric basalts of Units $A_{1}$ and $A_{2}$ are less calcic than those of Subunits $A_{3}, B_{1}$, and $B_{2}$, and they do not show normal zoning at the rim. The composition of the groundmass plagioclase is nearly constant except for the plagioclase of Subunit $\mathrm{A}_{3}$, which are lower in $\mathrm{Ca} /(\mathrm{Ca}+\mathrm{Na})$ ratio in accord with the low normative $\mathrm{An} /(\mathrm{An}+\mathrm{Ab})$ ratio of host $\mathrm{A}_{3}$ basalt as compared with other basalts of Hole 396B. Figure 20 also illustrates that composition of groundmass plagioclase in both variolitic and intersertal interior zones of pillows is nearly the same. The element partition relations between glass and groundmass plagioclase core are very similar to those in the 1-atmosphere equilibrium melting experiments of Fukuyama and Hamuro (this volume). The element partition findings of this study differ from the partitioning models of Kudo and Weill (1970) and of Drake (1975), i.e., about 10 mole per cent higher An content for analyzed plagioclase than the models at 1 atmosphere and $\left.1200^{\circ} \mathrm{C}\right)$.

\section{Chromian Spinel}

Chromian spinels are homogeneous within a grain, but the composition may vary from grain to grain. Representative analyses of chromian spinel are shown in Table 7 and plotted in the $\mathrm{Mg} /\left(\mathrm{Mg}+\mathrm{Fe}^{2+}\right)$ versus $\mathrm{Cr} /(\mathrm{Cr}+\mathrm{Al})$ and $\mathrm{Fe}^{3+}+\mathrm{Cr}+\mathrm{Al}$ ) diagrams (Figure 21 ). The overall compositional range of chromian spinel of Hole $396 \mathrm{~B}$ is narrow and is included within the compositional range of spinels from the Mid-Atlantic Ridge of $30^{\circ}-40^{\circ}$ North latitude (Sigurdsson and Schilling, 1975). There is a positive correlation between $\mathrm{Cr} /(\mathrm{Cr}+\mathrm{Al})$ and $\mathrm{Fe}^{2+} /\left(\mathrm{Mg}+\mathrm{Fe}^{2+}\right)$ ratios. In Figure 21, spinel compositions are shown to be related to the mode of occurrences. Spinels included in plagioclase are usually more magnesian than those in groundmass and in olivine phenocryst.

\section{Chemistry of Rocks and Glasses}

Major element chemical analyses of rocks and glasses were carried out by three methods: XRF analyses by Cambon (Leg 46 Scientific Party this volume), wet chemical analyses (gravimetric, flame photometric, and colorimetric) by Aoki, and electron microprobe analyses by Sato. The analytical results of the latter two are shown in Tables 8 and 9 , and the average bulk rock and glass compositions of each chemical unit are shown in Tables 10 and 11 . The neutron activation analyses of Cs by Okamoto on fresh glass are shown in Table 12. Because of the common occurrences of secondary minerals, the alteration effect is expected for the variolitic to more crystalline basaltic rocks. Some of the analyses of palagonite, smectites, mica, cryptocrystalline varioles, and altered interstitial materials are shown in Table 13. By comparing the analyses of fresh sideromelane glass and crystalline rocks of the sparsely-phyric basalt, it is seen that the composition of the crystalline rocks show much larger scatter than those of the glasses for $\mathrm{FeO}^{*}$ (total $\mathrm{Fe}$ as $\mathrm{FeO}$ ), $\mathrm{MgO}, \mathrm{K}_{2} \mathrm{O}$, and $\mathrm{H}_{2} \mathrm{O}$, thereby suggesting that these components have migrated during the sea-floor alteration. The alteration reduced $\mathrm{MgO}$ and $\mathrm{FeO}^{*}$, and increased $\mathrm{K}_{2} \mathrm{O}$ and $\mathrm{H}_{2} \mathrm{O}$ contents. Oxidation index $\left(\mathrm{Fe}^{3+} /\right.$ total $\left.\mathrm{Fe}\right)$ is much higher for crystalline rocks than for the glass sample of Section 10-1 (Table 8). These chemical changes of the 
TABLE 4

Representative Analysis of Olivine

\begin{tabular}{|c|c|c|c|c|c|c|c|c|c|c|c|c|c|c|c|c|c|c|c|c|c|}
\hline Analysis No. & 1 & 2 & 3 & 4 & 5 & 6 & 7 & 8 & 9 & 10 & 11 & 12 & 13 & 14 & 15 & 16 & 17 & 18 & 19 & 20 & 21 \\
\hline $\begin{array}{c}\text { Sample } \\
\text { (Interval in cm) }\end{array}$ & $\begin{array}{c}5-2, \\
26-32 \\
\end{array}$ & & $\begin{array}{r}7 \cdot 3 \\
5 \cdot 19 \\
\end{array}$ & & $\begin{array}{l}10-1, \\
49-57\end{array}$ & & & $\begin{array}{c}11-1, \\
110-117\end{array}$ & & $\begin{array}{l}13-2, \\
34-50\end{array}$ & & $\begin{array}{l}15-1, \\
92-96\end{array}$ & & & $\begin{array}{l}16-1, \\
73-82\end{array}$ & & & $\begin{array}{c}22-1 \\
104-121\end{array}$ & & & \\
\hline Piece No. & 4 & & $1 \mathrm{~B}$ & & $9(\mathrm{~A})$ & & & 12 & & $5(A)$ & & $12(\mathrm{~A})$ & & & $10(\mathrm{C})$ & & & 13 & & & \\
\hline Grain No. & $\mathrm{Ph}-2$ & $\mathrm{Ph}-2$ & 1 & 2 & $\mathrm{Ph}-4$ & Ph-8 & Ph-8 & 1 & 2 & $\mathrm{Ph}-3$ & $\mathrm{Ph}-3$ & 1 & 2 & 3 & 1 & 2 & 3 & $\mathrm{Ph}-2$ & $\mathrm{Ph}-2$ & $\mathrm{Ph}_{\mathrm{h}-3}$ & $\mathrm{Pl}_{1}-3$ \\
\hline Position & core & tim & $*^{\mathrm{a}}$ & $*^{\mathrm{a}}$ & rim & core & rim & $*^{\mathrm{a}}$ & $*^{2}$ & core & rim & $*^{\mathrm{a}}$ & *a & *a & $*^{\mathrm{a}}$ & $* \mathrm{a}$ & $* a$ & core & $\mathrm{rim}$ & core & $\mathrm{rim}$ \\
\hline $\mathrm{SiO}_{2}$ & 40.3 & 40.2 & 39.8 & 38.4 & 40.3 & 40.3 & 40.0 & 40.0 & 40.5 & 40.0 & 39.9 & 39.9 & 39.8 & 39.4 & 40.5 & 40.3 & 39.8 & 41.3 & 40.3 & 40.1 & 40.9 \\
\hline $\mathrm{Al}_{2} \mathrm{O}_{3}$ & & & 0.07 & 0.05 & & & & 0.04 & 0.08 & & & 0.06 & 0.07 & 0.05 & 0.06 & 0.09 & 0.07 & & & & \\
\hline $\mathrm{FeO}$ & 14.3 & 12.8 & 13.3 & 18.6 & 13.5 & 14.9 & 14.2 & 14.5 & 10.9 & 14.0 & 13.6 & 12.4 & 14.8 & 16.8 & 12.7 & 10.2 & 13.5 & 11.1 & 12.3 & 13.0 & 12.1 \\
\hline $\mathrm{MnO}$ & 0.22 & 0.20 & 0.22 & 0.28 & 0.20 & 0.22 & 0.20 & 0.21 & 0.16 & 0.25 & 0.19 & 0.21 & 0.23 & 0.25 & 0.20 & 0.18 & 0.21 & 0.15 & 0.22 & 0.24 & 0.23 \\
\hline $\mathrm{MgO}$ & 45.1 & 45.9 & 45.6 & 41.8 & 45.2 & 44.3 & 45.4 & 45.1 & 48.0 & 44.7 & 46.1 & 46.4 & 44.8 & 43.6 & 47.3 & 47.8 & 45.6 & 47.6 & 45.9 & 45.8 & 46.7 \\
\hline $\mathrm{CaO}$ & & & 0.28 & 0.25 & & & & 0.24 & 0.29 & & & 0.25 & 0.26 & 0.25 & 0.27 & 0.29 & 0.30 & & & & \\
\hline $\mathrm{Cr}_{2} \mathrm{O}_{3}$ & 0.04 & 0.04 & 0.05 & 0.04 & 0.05 & 0.03 & 0.03 & 0.05 & 0.06 & 0.06 & 0.07 & 0.07 & 0.06 & 0.02 & 0.07 & 0.09 & 0.08 & 0.06 & 0.06 & 0.06 & 0.07 \\
\hline $\mathrm{NiO}$ & 0.16 & 0.21 & 0.19 & 0.11 & 0.23 & 0.17 & 0.18 & 0.18 & 0.23 & 0.23 & 0.23 & 0.18 & 0.19 & 0.13 & 0.23 & 0.25 & 0.16 & 0.21 & 0.19 & 0.17 & 0.20 \\
\hline Total & 100.0 & 99.4 & 99.5 & 99.4 & 99.5 & 100.0 & 100.0 & 100.3 & 100.3 & 99.3 & 100.1 & 99.4 & 100.2 & 100.5 & 101.3 & 99.1 & 99.6 & 100.4 & 99.0 & 99.3 & 100.2 \\
\hline \multicolumn{22}{|l|}{ Oxygen $=4$} \\
\hline Si & 1.006 & 1.006 & 0.998 & 0.989 & 1.010 & 1.011 & 1.001 & 1.000 & 0.997 & 1.007 & 0.995 & 0.997 & 0.998 & 0.994 & 0.995 & 0.999 & 0.997 & 1.012 & 1.009 & 1.004 & 1.010 \\
\hline Al & & & 0.002 & 0.001 & & & & 0.001 & 0.002 & & & 0.002 & 0.002 & 0.002 & 0.002 & 0.003 & 0.002 & & & & \\
\hline $\mathrm{Fe}$ & 0.299 & 0.268 & 0.278 & 0.401 & 0.283 & 0.313 & 0.297 & 0.303 & 0.225 & 0.295 & 0.284 & 0.259 & 0.310 & 0.355 & 0.260 & 0.212 & 0.282 & 0.228 & 0.258 & 0.272 & 0.250 \\
\hline Mn & 0.005 & 0.004 & 0.005 & 0.006 & 0.004 & 0.005 & 0.004 & 0.004 & 0.003 & 0.005 & 0.004 & 0.004 & 0.005 & 0.005 & 0.004 & 0.004 & 0.004 & 0.003 & 0.005 & 0.005 & 0.005 \\
\hline $\mathrm{Mg}$ & 1.679 & 1.711 & 1.706 & 1.604 & 1.688 & 1.657 & 0.004 & 0.004 & 1.762 & 1.678 & 1.714 & 1.729 & 1.675 & 1.640 & 1.732 & 1.767 & 1.703 & 1.739 & 1.714 & 1.710 & 1.719 \\
\hline $\mathrm{Ca}$ & & & 0.008 & 0.007 & & & 1.693 & 1.681 & 0.008 & & & 0.007 & 0.007 & 0.007 & 0.007 & 0.008 & 0.008 & & & & \\
\hline Cr & 0.001 & 0.001 & 0.000 & 0.000 & 0.001 & 0.001 & & 0.007 & 0.000 & 0.001 & 0.001 & 0.001 & 0.000 & 0.000 & 0.001 & 0.001 & 0.001 & 0.001 & 0.001 & 0.001 & 0.001 \\
\hline $\mathrm{Ni}$ & 0.003 & 0.004 & 0.004 & 0.002 & 0.005 & 0.003 & 0.001 & 0.000 & 0.004 & 0.005 & 0.005 & 0.003 & 0.004 & 0.002 & 0.004 & 0.005 & 0.003 & 0.004 & 0.004 & 0.003 & 0.004 \\
\hline Total & 2.993 & 2.994 & 3.001 & 3.010 & 2.990 & 2.989 & 2.999 & 2.999 & 3.001 & 2.992 & 3.004 & 3.002 & 3.001 & 3.005 & 3.005 & 2.999 & 3.000 & 2.987 & 2.990 & 2.995 & 2.989 \\
\hline $\mathrm{Mg} /(\mathrm{Mg}+\mathrm{Fe})$ & 0.848 & 0.864 & 0.859 & 0.800 & 0.856 & 0.840 & 0.850 & 0.847 & 0.886 & 0.850 & 0.857 & 0.869 & 0.843 & 0.821 & 0.869 & 0.892 & 0.857 & 0.884 & 0.869 & 0.863 & 0.872 \\
\hline
\end{tabular}

$\mathrm{a}_{*}=$ Separated olivine crystals on epoxy mount are analyzed to avoid the contamination effect for Al and Ca. 


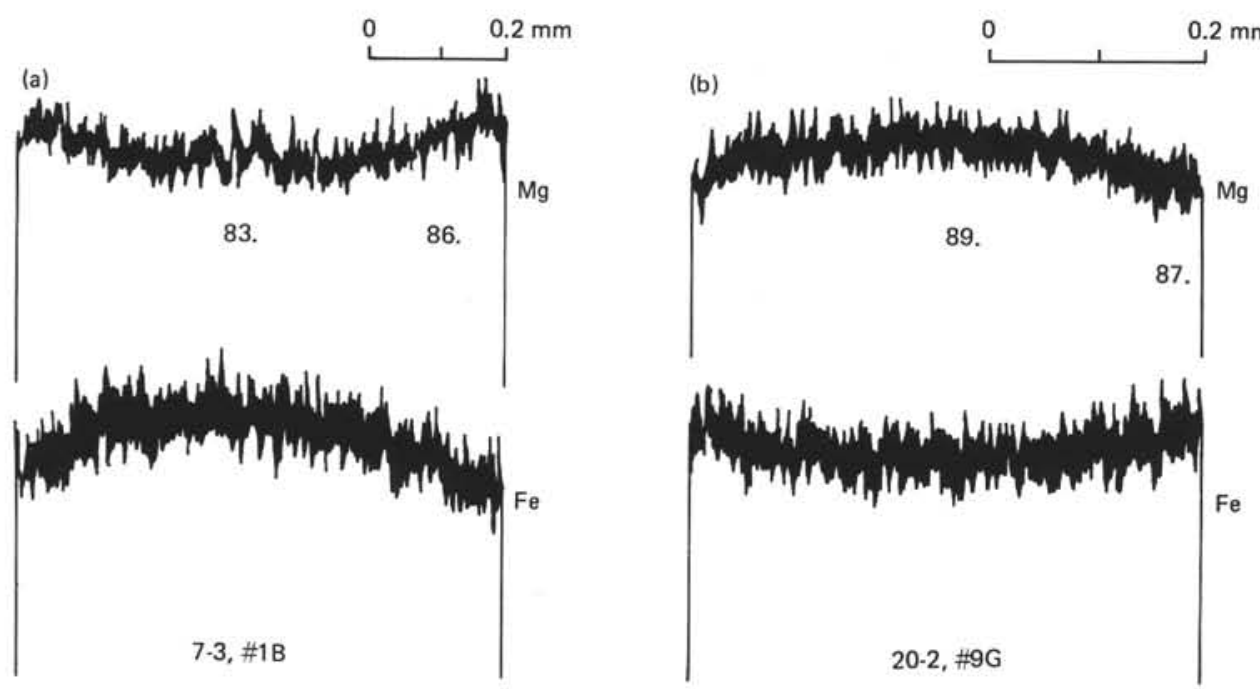

Figure 7. Electron microprobe scanning profiles of olivine phenocrysts showing both reverse (a) and normal (b) zonings.

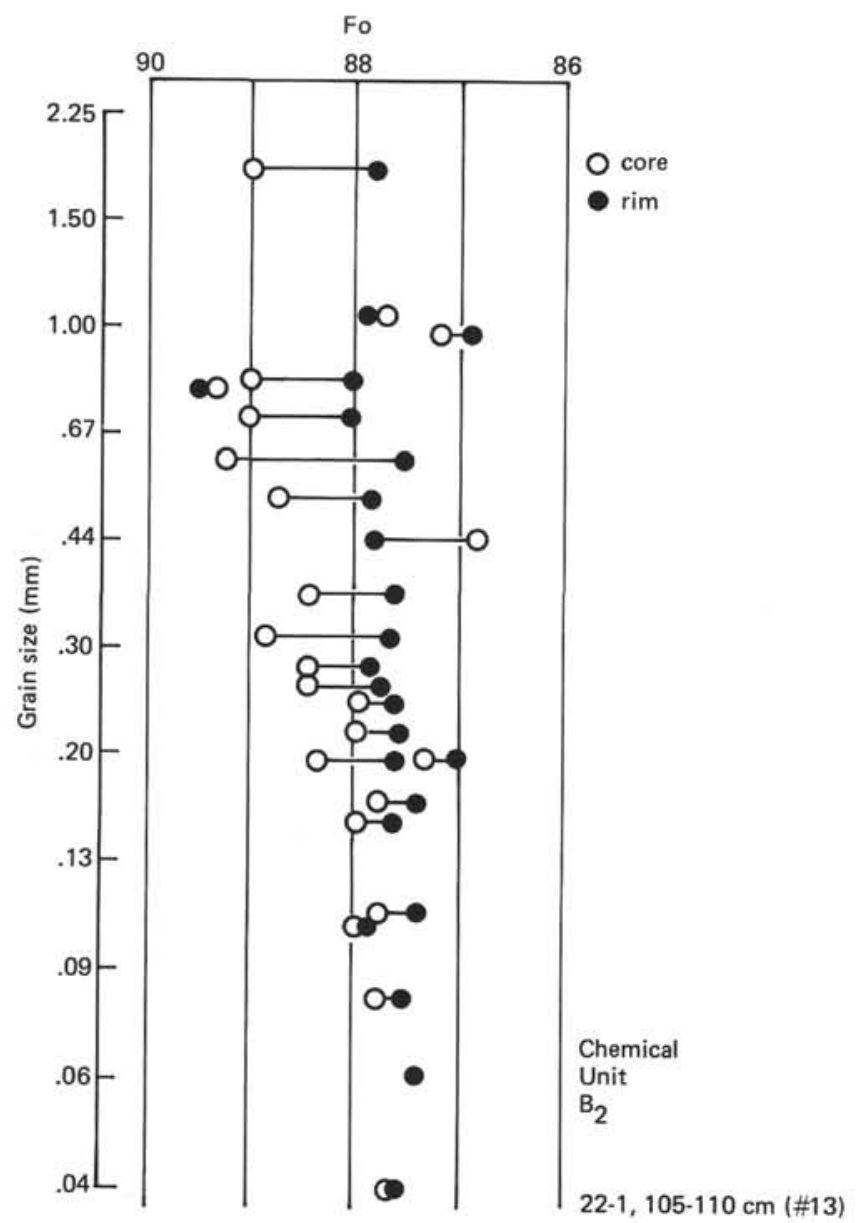

Figure 8. Compositional range of olivine phenocryst in Sample 22-1, \#13 plotted against grain size. Note the uniformity of the rim composition.

ocean-floor basalts are consistent with the data of Shido et al. (1973).

The compositional range of all the analyzed glasses of Hole $396 \mathrm{~B}\left(23^{\circ} \mathrm{N}\right)$ is shown in Figure 22 , together with

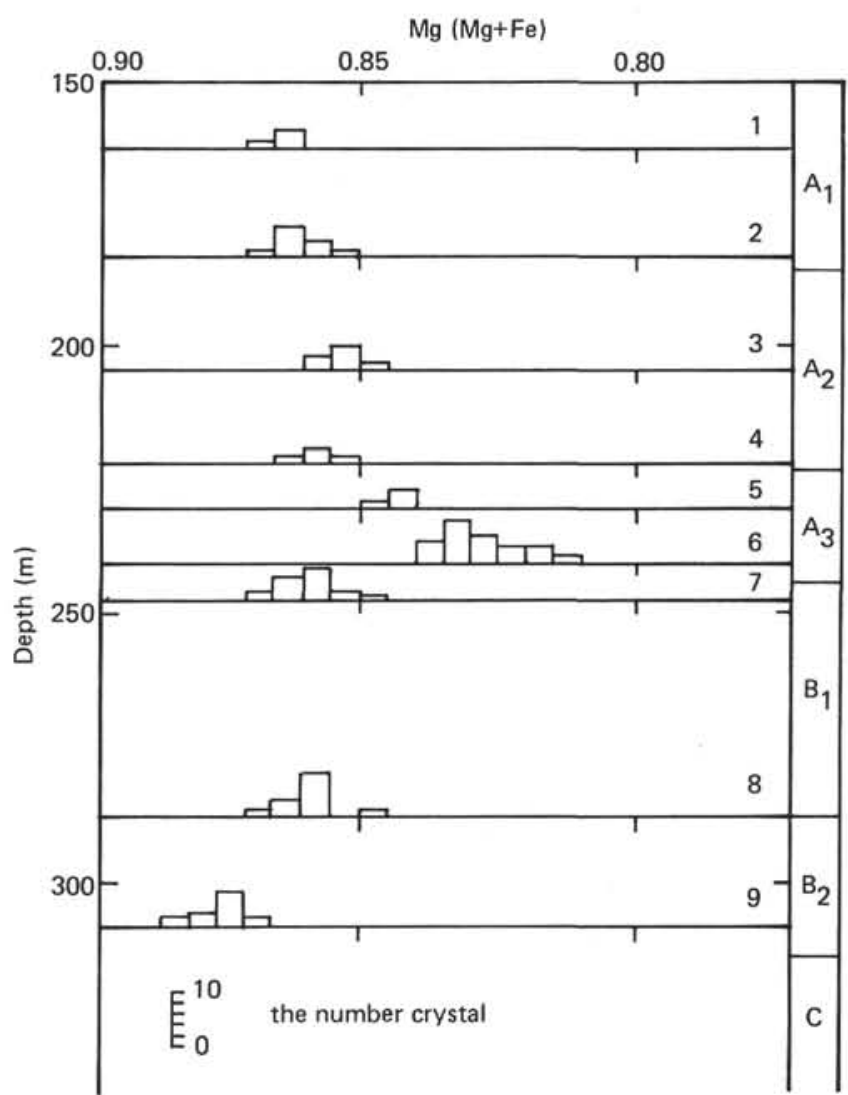

Figure 9. Stratigraphic variation of olivine composition at either phenocryst rim or groundmass core.

those of the glasses from the Atlantic Ocean (Melson et al., in press), and the FAMOUS region $\left(37^{\circ} \mathrm{N}\right)$, (Bryan and Moore, 1977). Figure 22 shows that the compositional range of Hole 396B glasses is generally very much restricted as compared with those of the FAMOUS glasses. Figure 23 shows that Hole $396 \mathrm{~B}$ glasses are higher in $\mathrm{TiO}_{2}$ content for the same $\mathrm{FeO}^{*} / \mathrm{MgO}$ ratio than are the FAMOUS glasses. Bulk $\mathrm{Al}_{2} \mathrm{O}_{3}$ content of the phyric basalts of 


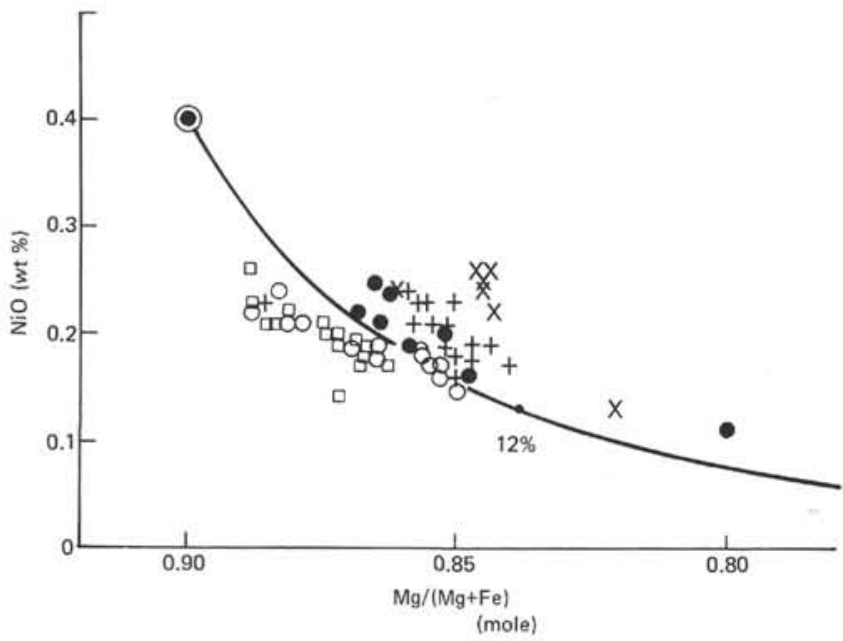

Figure 10. Nickel versus $\mathrm{Mg} /(\mathrm{Mg}+\mathrm{Fe})$ ratio of olivine. Solid circle: chemical Unit $A_{1}$, plus: $A_{2}$, cross: $A_{3}$, open circle: $B_{1}$, open square: $B_{2}$. Solid line represents the compositional variation of olivine during fractional crystallization of olivine, and the attached number denotes the degree of fractionation.

Hole $396 \mathrm{~B}$ ranges from 16.8 to 18.0 weight per cent and is much higher than the average $\mathrm{Al}_{2} \mathrm{O}_{3}$ content of ocean-floor basalt glasses (Figure 22). On the other hand, electron microprobe analyses of glasses as well as wet chemical analyses of separated groundmass (Table 8) show that the matrix of these phyric basalt contains 15.2 to 15.8 weight per cent of $\mathrm{Al}_{2} \mathrm{O}_{3}$. The high $\mathrm{Al}_{2} \mathrm{O}_{3}$ content of bulk phyric basalts may be attributed to the accumulation of plagioclase phenocryst.

In Figure 24, $\mathrm{FeO}-\mathrm{MgO}$ relations are shown for analyzed glasses. The figure demonstrates that each chemical unit has its own compositional range, and is very uniform as to the major element chemistry. The compositional gaps among chemical units suggest that these basalts are not derived by the successive eruption from a single magma chamber, which had gradual compositional gradient in it. Because of the supposed short time interval between the eruptions of the chemical units which belong to the same magnetic unit (the constant magnetic inclination within a unit suggests the time interval is short enough not to cause the secular variation of magnetic field), close petrogentic consanguinity would be expected for these chemical units. Chemical Subunits $A_{1}$ and $A_{2}$ belong to magnetic Unit 1 , and $B_{1}$ and $B_{2}$ belong to magnetic Unit 3 (Figure 2). Both of these pairs of chemical units show similar compositional relations, such that as $\mathrm{MgO}$ decreases from $\mathrm{A}_{1}$ to $\mathrm{A}_{2}$, or $\mathrm{FeO}, \mathrm{TiO}_{2}$, and $\mathrm{Na}_{2} \mathrm{O}$ increase from $\mathrm{B}_{2}$ to $\mathrm{B}_{1}$, and $\mathrm{CaO}$ and $\mathrm{Al}_{2} \mathrm{O}_{3}$ decrease. These compositional variations agree with the general fractionation trends of ocean-floor basalt (Kay et al., 1970; Miyashiro et al., 1969). The crystal fractionation model for these Leg 46 basalts will be discussed in the following chapter.

\section{DISCUSSIONS}

\section{Fractional Crystallization of Leg 46 Basalts}

As shown in the previous section, chemical units within a magnetic unit display compositional variations common in ocean-floor basalts. $\mathrm{MgO}, \mathrm{Al}_{2} \mathrm{O}_{3}$, and $\mathrm{CaO}$ decrease and $\mathrm{FeO}, \mathrm{TiO}_{6}$, and $\mathrm{Na}^{2}$ increase from the chemical Subunit $\mathrm{A}_{1}$ to $A_{2}$, and from $B_{2}$ to $B_{1}$. These compositional relations are examined in light of the fractional crystallization model, involving olivine, plagioclase, and Ca-rich clinopyroxene as fractionating phases. Because the compositional range of basalt is narrow, compositions of the fractionating phases were kept constant except for plagioclase. Plagioclase phenocrysts in hole $396 \mathrm{~B}$ basalt show rather wide compositional range, so that plagioclase compositions are adjusted to give the best fit of the calculation. Table 14 compares the calculated compositions with the analyzed compositions, showing both of these compositions to coincide within error of analyses. The result indicates that plagioclase and $\mathrm{Ca}$-rich clinopyroxene are the major phases participating in the fractional crystallization.

Because normative components of plagioclase, Ca-rich pyroxene, hypersthene, and olivine or quartz comprise about 95 per cent of ocean-floor basalt composition, quaternary system olivine-plagioclase-Ca pyroxene-silica well illustrates their compositional relations. Figure 25 illustrates the projections of glass compositions of Leg 46, as well as those of FAMOUS region and East Pacific, on the ternary diagrams olivine-Ca pyroxene-silica and plagioclase-olivine-Ca pyroxene, which terminate the quaternary system. In this figure, compositions of sparsely-phyric basalts of Subunits $A_{1}$ and $A_{2}$ and phyric basalts of $B_{1}$ and $B_{2}$ show different trends, the former being more enriched in olivine component than the latter. Both of these trends are nearly parallel to the projected olivine-plagioclase-Ca-rich clinopyroxene "quaternary", cotectic line drawn by Shibata (1976), suggesting that the trends were controlled by these three crystalline phases. Figure 26 shows that $\mathrm{Mg} /(\mathrm{Mg}+\mathrm{Fe})$ ratio decreases as silica component increases in the quaternary system, supporting the fractional crystallization model in the formation of the compositional trends. The compositions of Subunit $\mathrm{A}_{3}$ and Unit $\mathrm{C}$ do not lie on these trends in Figures 25 and 26; hence, they have no direct genetic relationships to the others.

Basaltic glasses of Leg 46, as a whole, have a rather restricted compositional range and are lower in $\mathrm{Mg} /(\mathrm{Mg}+\mathrm{Fe})$ ratio ( 0.60 to 0.65 , assuming the oxidation index of 0.1 ) than the most magnesian basaltic glass from the FAMOUS region (the ratio is 0.68 to 0.70 ). The low $\mathrm{Mg} /(\mathrm{Mg}+\mathrm{Fe})$ ratio of Leg 46 glasses indicates that they are evolved from the more primitive magmas through crystallization differentiation. Assuming the most magnesian basaltic glass from the FAMOUS region as a starting material, the composition of Leg 46 basalts were tried to fit by subtracting olivine, plagioclase, and Ca-rich clinopyroxene, but it was revealed that Leg 46 basaltic compositions cannot be derived from the most magnesian FAMOUS glass by this crystal fractionation model. The calculation always gives higher $\mathrm{FeO}$ contents than the observed value. The difference of the composition of primary magmas from both the Leg 46 and FAMOUS regions may reflect the differences of the depth and the degree of partial melting and the different compositions of the source peridotites between these regions.

Meanwhile, the degree of fractionation of olivine can be estimated approximately by $\mathrm{NiO}$ content and $\mathrm{Mg} /(\mathrm{Mg}+\mathrm{Fe})$ 
TABLE 5

Compositions of the Ca-rich Clinopyroxene Phenocryst and the Coexisting Minerals in Sample 396B-15-5, \#9

\begin{tabular}{|c|c|c|c|c|c|c|c|c|c|}
\hline \multicolumn{10}{|c|}{ Phenocryst Ca-rich Clinopyroxene } \\
\hline No. & 01 & 02 & 03 & 04 & 05 & 06 & 07 & 08 & $09^{*}$ \\
\hline $\mathrm{SiO}_{2}$ & 53.3 & 53.3 & 52.9 & 53.8 & 52.9 & 52.8 & 53.1 & 53.1 & 49.3 \\
\hline $\mathrm{TiO}_{2}$ & 0.42 & 0.49 & 0.49 & 0.45 & 0.50 & 0.51 & 0.49 & 0.42 & 1.66 \\
\hline $\mathrm{Al}_{2} \mathrm{O}_{3}$ & 2.60 & 2.79 & 2.99 & 2.73 & 3.18 & 3.02 & 3.13 & 2.84 & 6.60 \\
\hline $\mathrm{FeO}$ & 6.44 & 6.34 & 6.26 & 6.68 & 6.98 & 6.36 & 6.79 & 4.57 & 7.63 \\
\hline $\mathrm{MnO}$ & 0.17 & 0.17 & 0.18 & 0.18 & 0.19 & 0.21 & 0.18 & & 0.20 \\
\hline $\mathrm{MgO}$ & 18.2 & 18.0 & 17.1 & 18.2 & 18.3 & 17.8 & 18.1 & 17.2 & 14.4 \\
\hline $\mathrm{CaO}$ & 19.3 & 19.3 & 19.4 & 19.7 & 17.9 & 18.6 & 17.7 & 20.4 & 20.5 \\
\hline $\mathrm{Na}_{2} \mathrm{O}$ & 0.24 & 0.23 & 0.25 & 0.29 & 0.32 & 0.31 & 0.35 & 0.23 & 0.37 \\
\hline $\mathrm{K}_{2} \mathrm{O}$ & 0.00 & 0.00 & 0.01 & 0.00 & 0.01 & 0.00 & 0.00 & 0.04 & 0.00 \\
\hline $\mathrm{NiO}$ & 0.04 & 0.03 & 0.03 & 0.04 & 0.03 & 0.04 & 0.03 & 0.03 & 0.02 \\
\hline $\mathrm{Cr}_{2} \mathrm{O}_{3}$ & 0.22 & 0.23 & 0.25 & 0.22 & 0.24 & 0.24 & 0.25 & 0.18 & 0.29 \\
\hline Total & 100.87 & 100.86 & 99.85 & 102.25 & 100.46 & 99.87 & 100.14 & 99.01 & 100.85 \\
\hline \multicolumn{10}{|c|}{ Oxygen $=6.0$} \\
\hline $\mathrm{Si}$ & 1.932 & 1.929 & 1.934 & 1.926 & 1.921 & 1.929 & 1.932 & 1.951 & 1.810 \\
\hline Al & 0.111 & 0.119 & 0.129 & 0.115 & 0.136 & 0.130 & 0.134 & 0.123 & 0.286 \\
\hline $\mathrm{Ti}$ & 0.011 & 0.013 & 0.013 & 0.012 & 0.014 & 0.014 & 0.013 & 0.012 & 0.046 \\
\hline $\mathrm{Cr}$ & 0.006 & 0.006 & 0.006 & 0.005 & 0.006 & 0.006 & 0.006 & 0.006 & 0.008 \\
\hline $\mathrm{Fe}$ & 0.195 & 0.192 & 0.191 & 0.200 & 0.212 & 0.194 & 0.207 & 0.140 & 0.234 \\
\hline Mn & 0.005 & 0.005 & 0.006 & 0.006 & 0.006 & 0.006 & 0.006 & & 0.006 \\
\hline $\mathrm{Ni}$ & 0.001 & 0.001 & 0.001 & 0.001 & 0.001 & 0.001 & 0.001 & 0.001 & 0.000 \\
\hline $\mathrm{Mg}$ & 0.982 & 0.974 & 0.934 & 0.970 & 0.990 & 0.969 & 0.983 & 0.940 & 0.788 \\
\hline $\mathrm{Ca}$ & 0.748 & 0.748 & 0.762 & 0.757 & 0.696 & 0.729 & 0.691 & 0.801 & 0.805 \\
\hline $\mathrm{Na}$ & 0.017 & 0.016 & 0.018 & 0.020 & 0.023 & 0.022 & 0.024 & 0.016 & 0.027 \\
\hline K & 0.000 & 0.000 & 0.001 & 0.000 & 0.001 & 0.000 & 0.000 & 0.002 & 0.000 \\
\hline Total & 4.008 & 4.003 & 3.995 & 4.012 & 4.006 & 4.000 & 3.997 & 3.992 & 4.010 \\
\hline $\mathrm{Mg} /(\mathrm{Mg}+\mathrm{Fe})$ & 0.835 & 0.836 & 0.830 & 0.832 & 0.824 & 0.833 & 0.826 & 0.870 & 0.777 \\
\hline $\mathrm{Ca}$ & 388 & 390 & 404 & 390 & 366 & 386 & 368 & 426 & 440 \\
\hline $\mathrm{Mg}$ & 511 & 510 & 495 & 507 & 522 & 512 & 523 & 500 & 432 \\
\hline $\mathrm{Fe}$ & 101 & 100 & 101 & 103 & 111 & 103 & 110 & 075 & 128 \\
\hline
\end{tabular}

\begin{tabular}{|c|c|c|c|c|c|c|}
\hline \multicolumn{7}{|c|}{ Groundmass Ca-rich Clinopyroxene } \\
\hline No. & 11 & 12 & 13 & 14 & 15 & 16 \\
\hline $\mathrm{SiO}_{2}$ & 48.6 & 49.4 & 49.2 & 48.7 & 50.5 & 48.7 \\
\hline $\mathrm{TiO}_{2}$ & 1.84 & 1.78 & 2.05 & 1.97 & 1.64 & 1.52 \\
\hline $\mathrm{Al}_{2} \mathrm{O}_{3}$ & 4.64 & 5.51 & 5.59 & 6.20 & 2.91 & 3.52 \\
\hline $\mathrm{FeO}$ & 10.6 & 9.11 & 11.21 & 8.47 & 12.4 & 9.23 \\
\hline $\mathrm{MnO}$ & 0.22 & 0.19 & 0.23 & 0.18 & 0.32 & 0.25 \\
\hline $\mathrm{MgO}$ & 13.3 & 13.7 & 12.3 & 13.5 & 13.2 & 13.5 \\
\hline $\mathrm{CaO}$ & 19.3 & 20.1 & 19.9 & 21.2 & 19.0 & 20.2 \\
\hline $\mathrm{Na}_{2} \mathrm{O}$ & 0.43 & 0.44 & 0.45 & 0.45 & 0.50 & 0.45 \\
\hline $\mathrm{K}_{2} \mathrm{O}$ & 0.01 & 0.00 & 0.01 & 0.02 & 0.05 & 0.01 \\
\hline $\mathrm{NiO}$ & 0.01 & 0.02 & 0.02 & 0.02 & 0.02 & 0.03 \\
\hline $\mathrm{Cr}_{2} \mathrm{O}_{3}$ & 0.25 & 0.35 & 0.20 & 0.24 & 0.04 & 0.12 \\
\hline Total & 99.2 & 100.6 & 101.1 & 100.8 & 100.5 & 97.4 \\
\hline \multicolumn{7}{|l|}{ Oxygen $=6.0$} \\
\hline $\mathrm{Si}$ & 1.839 & 1.833 & 1.830 & 1.803 & 1.896 & 1.870 \\
\hline $\mathrm{Al}$ & 0.207 & 0.241 & 0.245 & 0.271 & 0.129 & 0.159 \\
\hline $\mathrm{Ti}$ & 0.052 & 0.050 & 0.058 & 0.055 & 0.046 & 0.044 \\
\hline $\mathrm{Cr}$ & 0.007 & 0.010 & 0.005 & 0.006 & 0.000 & 0.002 \\
\hline $\mathrm{Fe}$ & 0.335 & 0.283 & 0.349 & 0.262 & 0.389 & 0.297 \\
\hline Mn & 0.007 & 0.006 & 0.007 & 0.006 & 0.010 & 0.008 \\
\hline $\mathrm{Ni}$ & 0.000 & 0.000 & 0.000 & 0.000 & 0.000 & 0.001 \\
\hline $\mathrm{Mg}$ & 0.753 & 0.757 & 0.682 & 0.744 & 0.738 & 0.775 \\
\hline $\mathrm{Ca}$ & 0.785 & 0.798 & 0.793 & 0.840 & 0.764 & 0.832 \\
\hline $\mathrm{Na}$ & 0.031 & 0.032 & 0.033 & 9,933 & 0.037 & 0.034 \\
\hline K & 0.001 & 0.000 & 0.001 & 0.001 & 0.002 & 0.001 \\
\hline Total & 4.017 & 4.010 & 4.003 & 4.021 & 4.011 & 4.023 \\
\hline $\mathrm{Mg} /(\mathrm{Mg}+\mathrm{Fe})$ & 0.691 & 0.729 & 0.664 & 0.741 & 0.656 & 0.719 \\
\hline $\mathrm{Ca}$ & 420 & 434 & 434 & 454 & 404 & 440 \\
\hline $\mathrm{Mg}$ & 401 & 413 & 375 & 404 & 391 & 403 \\
\hline $\mathrm{Fe}$ & 179 & 153 & 190 & 142 & 205 & 158 \\
\hline
\end{tabular}


TABLE 5 - Continued

\begin{tabular}{|c|c|c|c|c|c|c|c|c|}
\hline \multicolumn{9}{|c|}{ Plagioclase } \\
\hline \multicolumn{6}{|c|}{ Phenocryst associated with the clinopyroxene phenocryst } & \multicolumn{3}{|c|}{ Groundmass } \\
\hline $\begin{array}{l}\text { No. } \\
\text { Grain No. }\end{array}$ & $\begin{array}{c}21 \\
1\end{array}$ & $\begin{array}{c}22 \\
1\end{array}$ & $\begin{array}{c}23 \\
1\end{array}$ & $\begin{array}{c}24 \\
6\end{array}$ & $\begin{array}{c}25 \\
6\end{array}$ & $\begin{array}{l}26 \\
12\end{array}$ & $\begin{array}{l}27 \\
13\end{array}$ & $\begin{array}{l}28 \\
13\end{array}$ \\
\hline Position & core & core & $\mathrm{rim} / \mathrm{cpx}$ & core & rim/g.m. & core & core & rim \\
\hline $\mathrm{SiO}_{2}$ & 53.0 & 52.9 & 50.8 & 53.5 & 52.9 & 52.4 & 51.7 & 54.5 \\
\hline $\mathrm{TiO}_{2}$ & 0.10 & 0.09 & 0.05 & 0.11 & 0.14 & 0.11 & 0.12 & 0.17 \\
\hline $\mathrm{Al}_{2} \mathrm{O}_{3}$ & 29.3 & 29.7 & 30.6 & 29.3 & 29.6 & 30.0 & 30.1 & 27.7 \\
\hline $\mathrm{FeO}$ & 0.53 & 0.54 & 0.56 & 0.59 & 0.73 & 0.70 & 0.70 & 1.00 \\
\hline $\mathrm{MgO}$ & 0.38 & 0.32 & 0.41 & 0.24 & 0.33 & 0.30 & 0.31 & 0.36 \\
\hline $\mathrm{CaO}$ & 13.0 & 13.3 & 14.9 & 13.0 & 13.4 & 13.8 & 13.8 & 11.9 \\
\hline $\mathrm{Na}_{2} \mathrm{O}$ & 4.06 & 3.83 & 3.13 & 4.18 & 3.91 & 3.61 & 3.59 & 4.66 \\
\hline $\mathrm{K}_{2} \mathrm{O}$ & 0.06 & 0.07 & 0.05 & 0.07 & 0.07 & 0.05 & 0.05 & 0.07 \\
\hline Total & 100.5 & 100.7 & 100.4 & 101.0 & 101.1 & 100.9 & 100.3 & 100.4 \\
\hline \multicolumn{9}{|l|}{ Oxygen $=8$} \\
\hline $\mathrm{Si}$ & 2.397 & 2.386 & 2.312 & 2.405 & 2.384 & 2.364 & 2.348 & 2.464 \\
\hline $\mathrm{Al}$ & 1.562 & 1.580 & 1.640 & 1.555 & 1.569 & 1.595 & 1.612 & 1.478 \\
\hline $\mathrm{Ti}$ & 0.003 & 0.003 & 0.002 & 0.004 & 0.005 & 0.004 & 0.004 & 0.006 \\
\hline $\mathrm{Fe}$ & 0.020 & 0.020 & 0.021 & 0.022 & 0.028 & 0.026 & 0.027 & 0.038 \\
\hline $\mathrm{Mg}$ & 0.026 & 0.022 & 0.028 & 0.016 & 0.022 & 0.020 & 0.021 & 0.024 \\
\hline $\mathrm{Ca}$ & 0.630 & 0.641 & 0.725 & 0.627 & 0.654 & 0.665 & 0.670 & 0.576 \\
\hline $\mathrm{Na}$ & 0.356 & 0.335 & 0.276 & 0.364 & 0.341 & 0.316 & 0.317 & 0.409 \\
\hline K & 0.003 & 0.004 & 0.003 & 0.004 & 0.004 & 0.003 & 0.003 & 0.004 \\
\hline Total & 4.998 & 4.990 & 5.006 & 4.998 & 4.999 & 4.994 & 5.002 & 4.998 \\
\hline $\mathrm{Ca} /(\mathrm{Ca}+\mathrm{Na})$ & 0.638 & 0.657 & 0.724 & 0.632 & 0.654 & 0.678 & 0.679 & 0.585 \\
\hline
\end{tabular}

Groundmass

\begin{tabular}{lccc}
\multicolumn{1}{c}{ No. } & 31 & 32 & 33 \\
\hline $\mathrm{SiO}_{2}$ & 40.0 & 39.7 & 39.8 \\
$\mathrm{FeO}$ & 15.1 & 18.5 & 17.4 \\
$\mathrm{MnO}$ & 0.26 & 0.31 & 0.32 \\
$\mathrm{MgO}$ & 43.5 & 41.0 & 41.9 \\
$\mathrm{CaO}$ & 0.43 & 0.52 & 0.51 \\
$\mathrm{NiO}$ & 0.18 & 0.11 & 0.12 \\
$\mathrm{Total}$ & 99.5 & 100.1 & 99.8 \\
Oxygen $=4$ & & & \\
$\mathrm{Si}$ & 1.011 & 1.012 & 1.011 \\
$\mathrm{Fe}$ & 0.319 & 0.394 & 0.370 \\
$\mathrm{Mn}$ & 0.006 & 0.007 & 0.007 \\
$\mathrm{Mg}$ & 0.639 & 1.558 & 1.586 \\
$\mathrm{Ca}$ & 0.012 & 0.014 & 0.014 \\
$\mathrm{Ni}$ & 0.004 & 0.002 & 0.002 \\
$\mathrm{Total}$ & 2.991 & 2.987 & 2.990 \\
$\mathrm{Mg} /(\mathrm{Mg}+\mathrm{Fe})$ & 0.837 & 0.798 & 0.811 \\
\hline
\end{tabular}

${ }^{\mathrm{a}}$ Rim of phenocryst (ca. $10 \mathrm{~mm}$ from the periphery). ratio of magma, because olivine effectively removes nickel and magnesium from magma. The effects of olivine fractionation on $\mathrm{MgO}-\mathrm{FeO}$ and $\mathrm{NiO}-\mathrm{MgO}$ compositional relations are shown in Figures 27. The initial compositions were chosen to be in partition equilibrium with the supposed mantle olivine $(\mathrm{NiO}=0.40$ wt. $\%, \mathrm{Fo}=90 \%)$, and have $\mathrm{MgO}=10.0$ wt. per cent, $\mathrm{FeO}^{2}=6.6$ per cent, and $\mathrm{NiO}$ $=0.038$ per cent $($ Sato, 1977). These figures demonstrate that about 5 to 8 per cent of olivine was removed from the primary magma in the formation of Leg 46 basalts. NiO content of olivine phenocryst is around 0.2 weight per cent (Figure 10), which also supports the value of the degree of olivine fractionation. Though olivine is expected to be one of the major phases to crystallize in the early stage of the crystallization of ascending basaltic magmas, plagioclase and Ca-rich clinopyroxene, and also minor amount of chromian spinel may be incorporated in the fractional crystallization. Primitive basaltic glasses $(\mathrm{Mg} /(\mathrm{Mg}+\mathrm{Fe})=$ 0.68-0.70) from ocean floor generally have higher $\mathrm{CaO}$ and $\mathrm{Al}_{2} \mathrm{O}_{3}$ contents than Leg 46 basalt, suggesting that both plagioclase and Ca-rich clinopyroxene in addition to olivine are the major fractionating phases in the derivation of Leg 46 basalts.

The fractionation model discussed above shows the important role of Ca-rich clinopyroxene, which is discordant with the very rare occurrence of $\mathrm{Ca}$-rich 


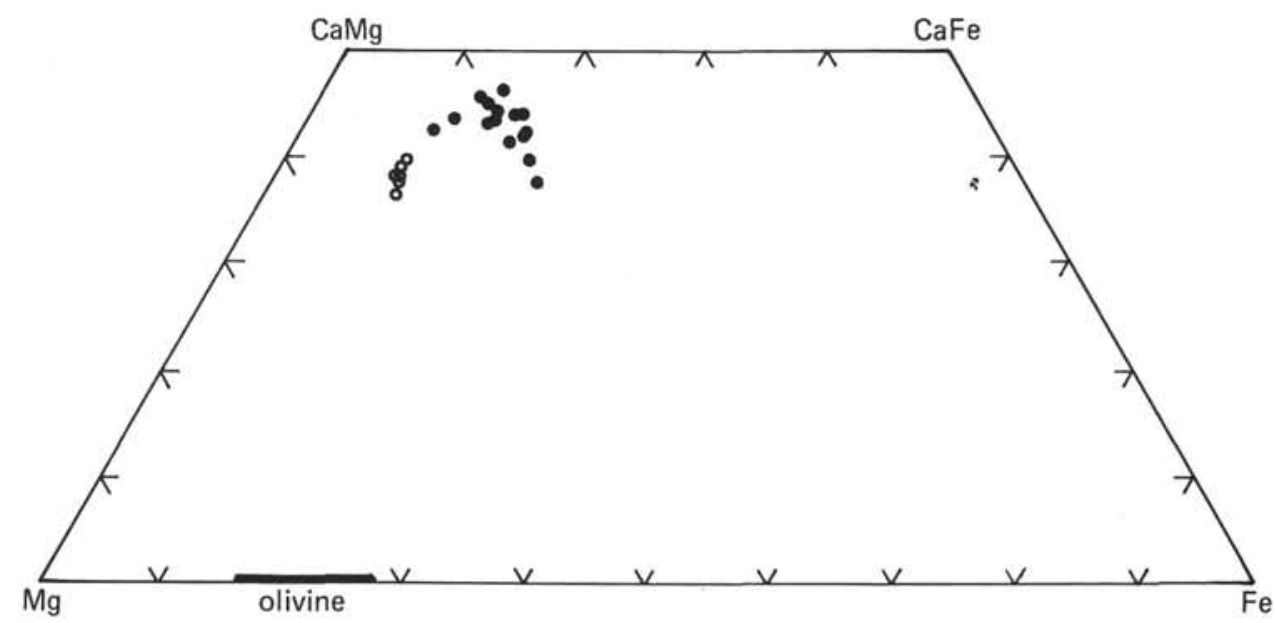

Figure 11. Composition of Ca-rich clinopyroxene phenocryst (open circle), groundmass clinopyroxene (solid circle), and groundmass olivine (bar) in the lower part of the massive lava, lithologic Unit 2. Sample 15-5, 70-78 cm.

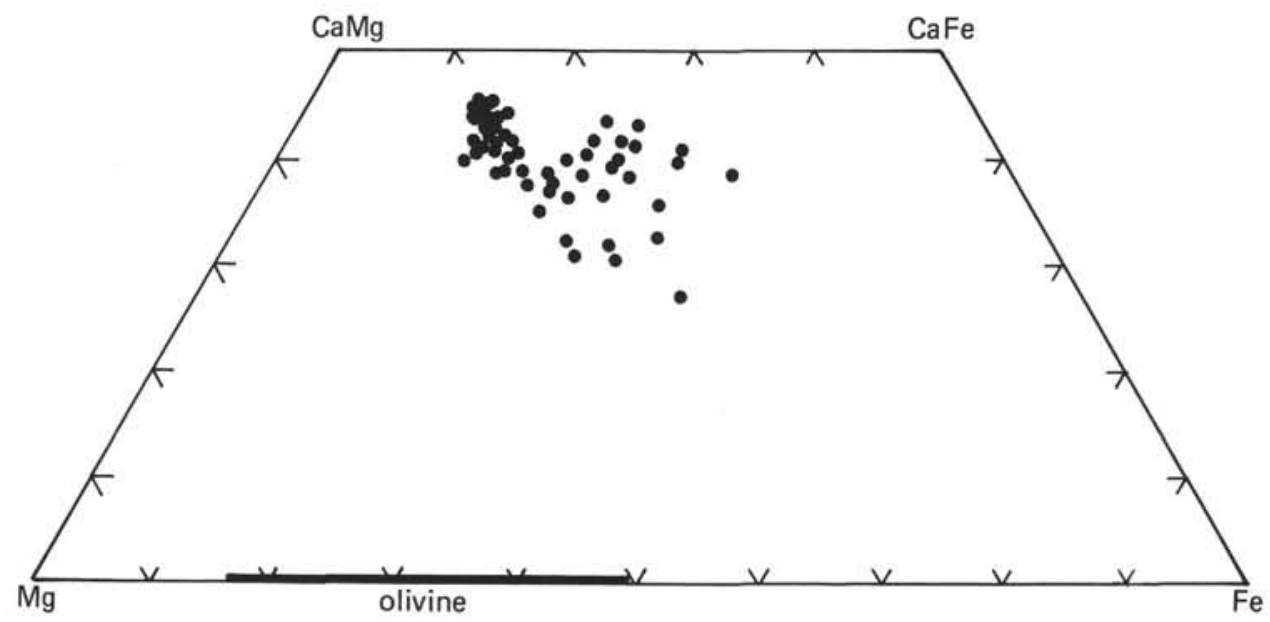

Figure 12. Composition of groundmass clinopyroxene and olivine in the central part of the massive lava. Sample 15-3, 15-23 cm.

clinopyroxene phenocryst in these basaltic rocks. This apparent discrepancy may indicate that there were two stages of intratelluric crystallization for Leg 46 basalts. The crystallization of the first stage determined the main compositional trends and involved olivine, plagioclase, Ca-rich clinopyroxene, and minor amounts of chromian spinel. It took place at a deep level of magma reservoir, while, the second stage is represented by most of the phenocrysts of olivine and plagioclase. It is possible to interpret the large rounded phenocrysts of olivine, plagioclase, and Ca-rich clinopyroxene in the sparsely phyric basalts to represent the first stage of crystallization.

\section{Temperature of Magmas}

The eruption temperatures of Hole 396B basaltic magmas were calculated using the method of Roeder and Emslie (1970), which is based on the observation that $\mathrm{MgO}$ and $\mathrm{FeO}$ contents of magma in equilibrium with olivine at 1 atmosphere are related to the temperature. The glass analyses are used for calculation, because these sideromelane glasses are saturated with olivine, and hardly affected by the crystallization during quenching. The temperature was calculated for each chemical unit as shown in Table 15. The absolute error of the obtained temperature is about $15^{\circ} \mathrm{C}$ (Roeder and Emslie, 1970), while its relative error may be within $5^{\circ} \mathrm{C}$. The calculated temperature is rather uniform among chemical units and ranges from $1202^{\circ}$ to $1217^{\circ} \mathrm{C}$, which accords well with the result of 1-atmosphere melting experiments of Fukuyama and Hamuro (this volume). The liquidus temperature of olivine, however, is affected by the dry pressure as well as volatile components of magma. The dry pressure of 0.5 kilobars, corresponding to the water depth of 5000 meters, may increase the olivine liquidus temperature by $4^{\circ} \mathrm{C}$ (Nicholls and Ringwood, 1973). On the other hand, $\mathrm{H}_{2} \mathrm{O}$ content of ocean-floor basalt is estimated to be 0.30 weight per cent (Moore and Schilling, 1973). The depression of liquidus temperature of olivine is calculated by Burnham's (1975) 


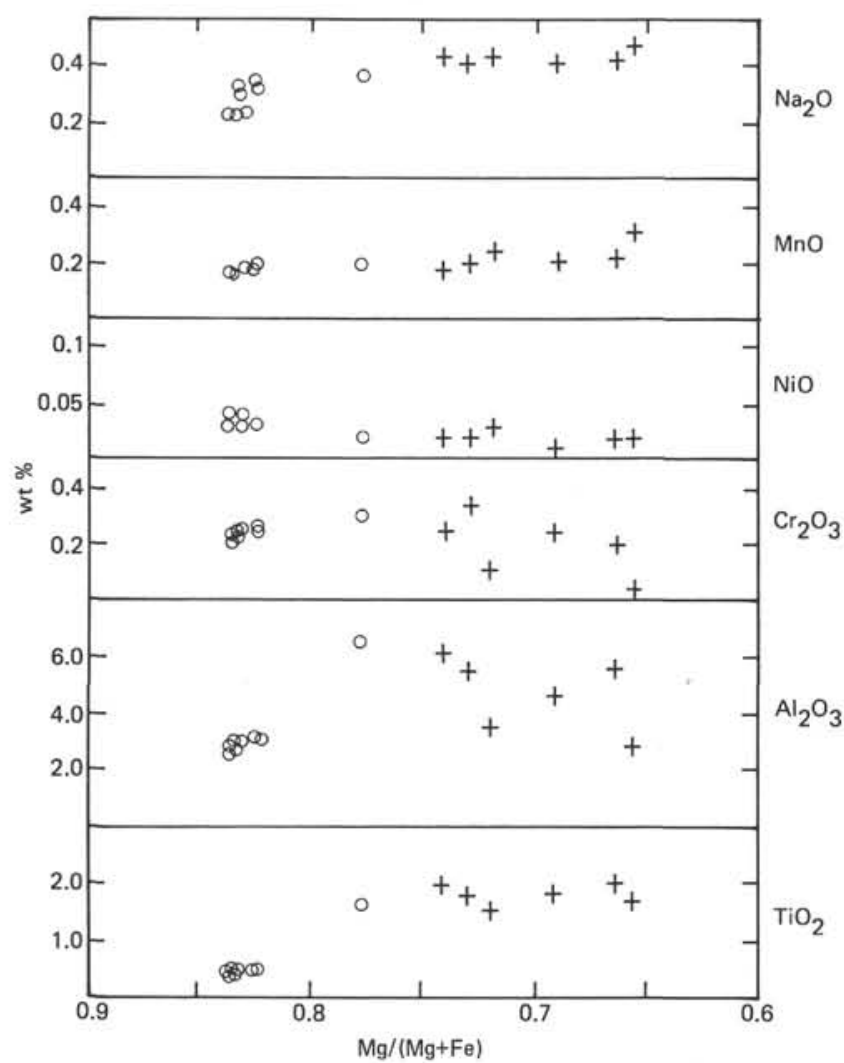

Figure 13. Minor element content of both phenocryst (open circle) and groundmass (cross) slinopyroxene. Sample 15-5, 70-77 cm (\#9).

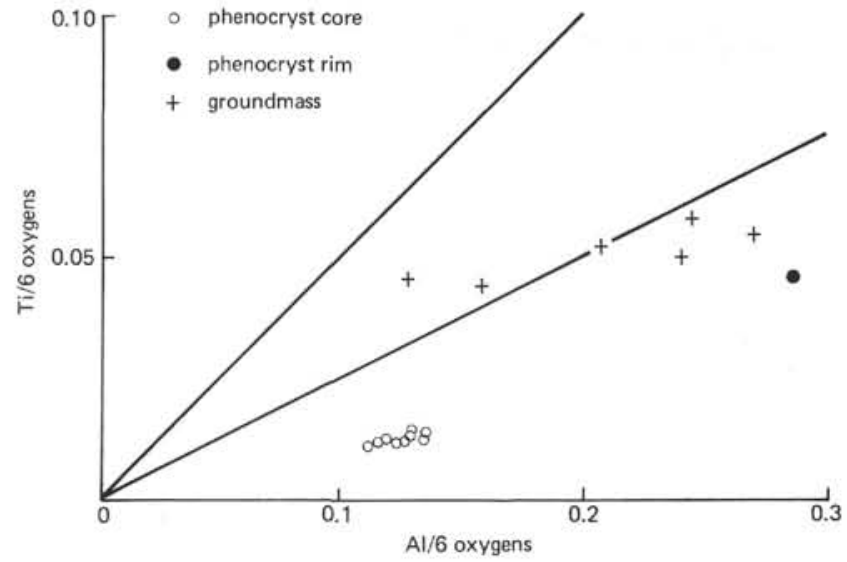

Figure 14. $T i$ and $A l$ relation of phenocryst and groundmass Ca-rich clinopyroxene.

model of the water solubility in silicate melts and using the experimental data of Nicholls and Ringwood (1973). Water content of 0.3 weight per cent, corresponding to 5.3 mole per cent of basaltic liquid, reduces the liquidus temperature by $13^{\circ} \mathrm{C}$. Though there remains uncertainty as to the effects of minor volatile components, such as $\mathrm{Co}_{2}$ and $\mathrm{SO}_{2}$ in the ocean-floor basaltic magmas (Anderson, 1975), the extrusion temperature of Hole $396 \mathrm{~B}$ basalt may be $1190-1210^{\circ} \mathrm{C}$ (Table 15 ).

\section{ACKNOWLEDGMENTS}

Critical comments on the manuscript by Drs. S. Banno and M. Yamasaki of Kanazawa University were most helpful. Dr. H.

TABLE 6

Representative Analyses of Plagioclase

\begin{tabular}{|c|c|c|c|c|c|c|c|c|c|c|c|c|c|c|c|}
\hline Analysis No. & 1 & 2 & 3 & 4 & 5 & 6 & 7 & 8 & 9 & 10 & 11 & 12 & 13 & 14 & $15^{\mathrm{a}}$ \\
\hline $\begin{array}{c}\text { Sample } \\
\text { (Interval in cm) }\end{array}$ & $\begin{array}{l}13-2 \\
34-50\end{array}$ & & & & $\begin{array}{l}16-1 \\
73-82\end{array}$ & & & & & $\begin{array}{c}22-1 \\
104-121\end{array}$ & & & & & $\frac{22-1,}{104-121}$ \\
\hline Piece No. & $5 \mathrm{~A}$ & & & & $10 \mathrm{C}$ & & & & & 13 & & & & & 13 \\
\hline Grain No. & $\mathrm{PH}-1$ & PH-1 & $\mathrm{PH}-1$ & $\mathrm{Gm} \cdot 5$ & $\mathrm{PH}-1$ & $\mathrm{PH}-1$ & PH-1 & $\mathrm{Ph}-1$ & $\mathrm{Gm}-21$ & $\mathrm{Ph}-8$ & $\mathrm{Ph}-1$ & $\mathrm{Ph}-1$ & $\mathrm{Ph}-1$ & $\mathrm{Gm}-17$ & Bulk \\
\hline Position & core & core & rim & core & core & core & $\begin{array}{l}\text { inner } \\
\text { rim }\end{array}$ & $\begin{array}{l}\text { outer } \\
\text { rim }\end{array}$ & core & core & core & core & $\begin{array}{c}\text { inner } \\
\text { rim }\end{array}$ & core & \\
\hline $\mathrm{SiO}_{2}$ & 49.3 & 50.9 & 51.8 & 51.5 & 47.3 & 48.3 & 50.4 & 54.8 & 52.5 & 47.6 & 49.3 & 48.4 & 50.4 & 51.2 & 48.25 \\
\hline $\mathrm{TiO}_{2}$ & 0.03 & 0.03 & 0.01 & 0.01 & 0.09 & 0.10 & 0.08 & 0.12 & 0.13 & 0.03 & 0.03 & 0.00 & 0.00 & 0.05 & 0.06 \\
\hline $\mathrm{Al}_{2} \mathrm{O}_{3}$ & 32.3 & 31.0 & 30.6 & 30.2 & 32.9 & 32.7 & 31.0 & 27.7 & 29.1 & 33.4 & 32.4 & 32.9 & 31.8 & 31.1 & 32.41 \\
\hline $\mathrm{FeO}$ & 0.52 & 0.48 & 0.55 & 0.73 & 0.35 & 0.37 & 0.45 & 0.59 & 0.84 & 0.29 & 0.36 & 0.37 & 0.44 & 0.66 & 0.88 \\
\hline $\mathrm{MnO}$ & 0.00 & 0.00 & 0.00 & 0.00 & 0.09 & 0.11 & 0.12 & 0.11 & 0.10 & 0.00 & 0.00 & 0.01 & 0.00 & 0.01 & 0.01 \\
\hline $\mathrm{MgO}$ & 0.29 & 0.24 & 0.27 & 0.32 & 0.26 & 0.38 & 0.44 & 0.53 & 0.75 & 0.32 & 0.35 & 0.33 & 0.37 & 0.43 & 0.70 \\
\hline $\mathrm{CaO}$ & 15.48 & 14.92 & 14.54 & 14.36 & 17.43 & 16.94 & Is.01 & 13.41 & 13.67 & 17.80 & 16.11 & 17.09 & 15.54 & 14.08 & 15.79 \\
\hline $\mathrm{Na}_{2} \mathrm{O}$ & 2.77 & 3.14 & 3.36 & 3.41 & 1.65 & 1.86 & 2.93 & 3.86 & 3.67 & 1.62 & 2.32 & 1.94 & 2.65 & 3.53 & 2.12 \\
\hline $\mathrm{K}_{2} \mathrm{O}$ & 0.03 & 0.03 & 0.03 & 0.02 & 0.03 & 0.04 & 0.05 & 0.06 & 0.05 & 0.02 & 0.03 & 0.02 & 0.02 & 0.02 & 0.04 \\
\hline Total & 99.7 & 100.7 & 101.2 & 100.6 & 100.1 & 100.8 & 100.5 & 101.2 & 100.9 & 101.1 & 100.9 & 101.1 & 101.3 & 101.1 & 100.26 \\
\hline \multicolumn{16}{|l|}{ Oxygen $=8$} \\
\hline Si & 2.266 & 2.308 & 2.334 & 2.336 & 2.175 & 2.202 & 2.292 & 2.459 & 2.375 & 2.168 & 2.238 & 2.201 & 2.275 & 2.3131 & 2.206 \\
\hline Al & 1.693 & 1.655 & 1.627 & 1.617 & 1.784 & 1.756 & 1.664 & 1.465 & 1.553 & 1.792 & 1.732 & 1.761 & 1.692 & 1.653 & 1.747 \\
\hline $\mathrm{Ti}$ & 0.001 & 0.001 & 0.002 & 0.002 & 0.003 & 0.003 & 0.003 & 0.004 & 0.005 & 0.001 & 0.001 & 0.001 & 0.001 & 0.002 & 0.002 \\
\hline $\mathrm{Fe}$ & 0.020 & 0.018 & 0.021 & 0.028 & 0.013 & 0.014 & 0.017 & 0.022 & 0.032 & 0.011 & 0.013 & 0.014 & 0.017 & 0.025 & $0.030^{\mathrm{b}}$ \\
\hline Mn & 0.000 & 0.000 & 0.000 & 0.000 & 0.004 & 0.004 & 0.005 & 0.004 & 0.004 & 0.000 & 0.000 & 0.000 & 0.000 & 0.000 & 0.000 \\
\hline $\mathrm{Mg}$ & 0.020 & 0.016 & 0.018 & 0.021 & 0.018 & 0.026 & 0.030 & 0.035 & 0.050 & 0.021 & 0.024 & 0.023 & 0.025 & 0.029 & 0.048 \\
\hline $\mathrm{Ca}$ & 0.762 & 0.725 & 0.702 & 0.698 & 0.859 & 0.827 & 0.732 & 0.644 & 0.662 & 0.868 & 0.783 & 0.832 & 0.752 & 0.681 & 0.774 \\
\hline $\mathrm{Na}$ & 0.247 & 0.276 & 0.294 & 0.300 & 0.147 & 0.165 & 0.259 & 0.336 & 0.322 & 0.143 & 0.204 & 0.171 & 0.232 & 0.309 & 0.188 \\
\hline K & 0.003 & 0.002 & 0.002 & 0.001 & 0.002 & 0.002 & 0.003 & 0.003 & 0.003 & 0.001 & 0.002 & 0.001 & 0.001 & 0.001 & 0.002 \\
\hline Total & 5.011 & 5.002 & 4.999 & 5.004 & 5.004 & 5.000 & 5.004 & 4.973 & 5.006 & 5.006 & 4.998 & 5.003 & 4.995 & 5.014 & 4.997 \\
\hline $\mathrm{Ca} /(\mathrm{Ca}+\mathrm{Na})$ & 0.755 & 0.724 & 0.705 & 0.699 & 0.854 & 0.834 & 0.739 & 0.657 & 0.673 & 0.859 & 0.793 & 0.830 & 0.764 & 0.688 & 0.800 \\
\hline
\end{tabular}

${ }_{b}^{a}$ Wet chemical analyses of separated plagioclase phenocryst. 


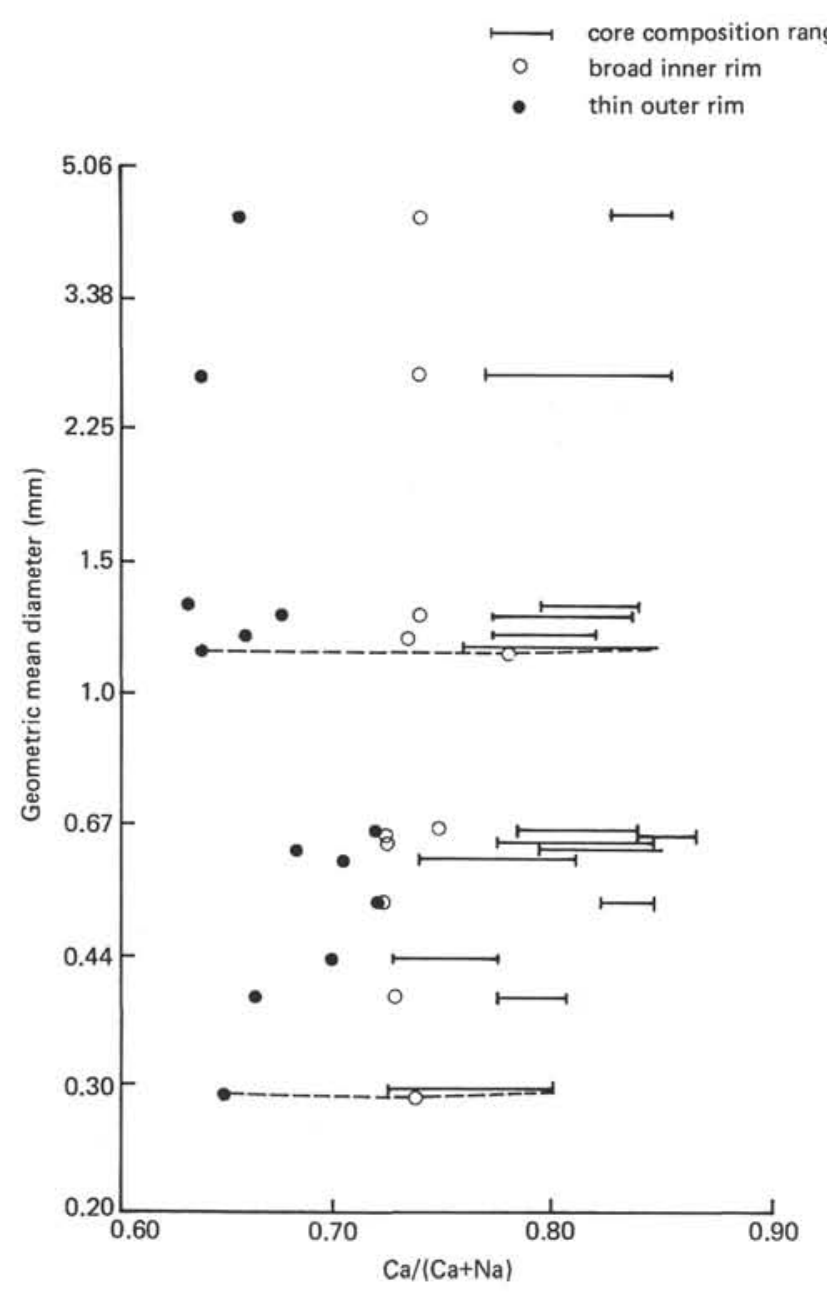

Figure 15. Composition of plagioclase phenocryst in phyric basalt Sample 16-1, 75-80 cm (\#10C).

Kurasawa of the Geological Survey of Japan kindly accommodated us with facilities for sample preparation and with the polished thin sections. Messrs. S. Kasajima and K. Nakamura of Kanazawa University made the polished thin sections, and drafted the figures, respectively. The typing of the manuscript was done by Mrs. Y. Fukuda and Miss Y. Shibuya of Kanazawa University. We gratefully acknowledge the contributions of all these individuals.

\section{REFERENCES}

Anderson, A.T., 1975. Some basaltic and andesitic gases, Rev. Geophys., Space Phys., v. 13, p. 37-55.

Bryan, W.B. and Moore, J.G., 1977. Compositional variations of young basalts in the Mid-Atlantic Ridge rift valley near lat $36^{\circ} 49^{\prime}$ N, Geol. Soc. Am. Bull., v. 88, p. 556-570.

Burnham, C.W., 1975. Water and magmas, a mixing madel, Geochim, Cosmochim, Acta, v. 39, p. 1077-1085.

Clague, D.A. and Bunch, T.E., 1976. Formation of ferrobasalt at East Pacific Midocean Spreading centers, J. Geophy Res., v. 81 , p. $4247-4256$.

Drake, M.J., 1976. Plagioclase-melt equilibria, Geochim, Cosmochim. Acta, v. 40, p. 457-465.

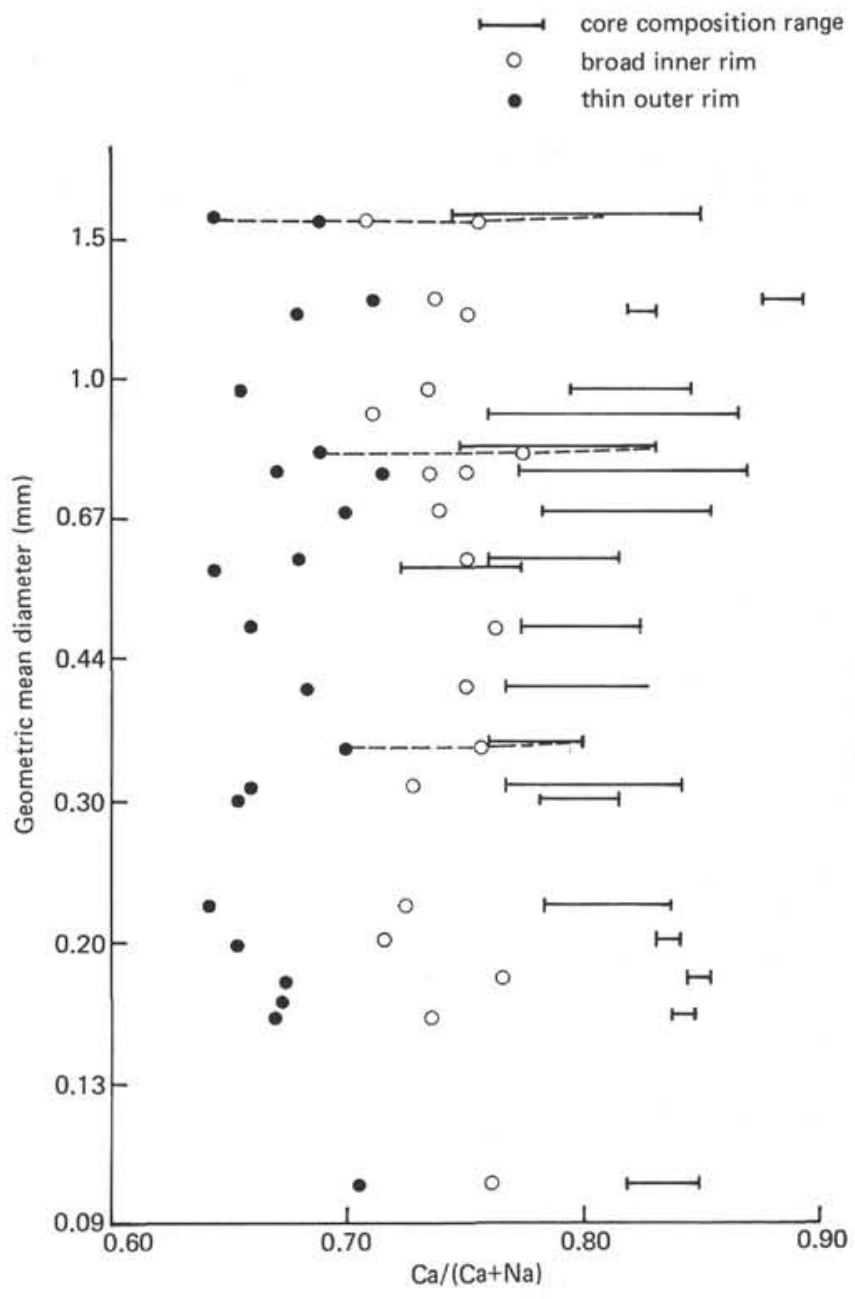

Figure 16. Composition of plagioclase phenocryst in phyric basalt Sample 17-1, 20-25 cm (\#2).

Dowty, E., Keil, K., and Prinz, M., 1974. Lunar pyroxene-phyric basalts: crystallazation under super cooled conditions, $J$. Petrol, v. 15, p. 415-453.

Hodges, F.N. and Papike, J.J., 1976. DSDP Site 334: magmatic cumulates from oceanic layer 3, J. Geophy. Res. v. 81, p. 4135-4151.

Kay, R., Hubbard, N.J. and Gast, P., 1970. Chemical characteristics and origin of oceanic ridge volcanic rocks, $J$. Geophy. Res., v. 75, p. 1585-1613.

Kudo, A.M. and Weill, D.F,, 1970. An igneous plagioclase thermometer, Contrib. Mineral. Petrol., v. 25, p. 52-65.

Kushiro, I., 1973. Origin of some magmas in oceanic and circum-oceanic regions, Tectonophysics, v. 17, p. 211-222.

Melson, W.G., Byerly, G., Nelen, J., O'Hearn, T., Wright, T., and Vallier, T., in press. A catalog of the major element chemistry of abyssal volcanic glasses.

Miyashiro, A., Shido, F., and Ewing, M., 1969. Diversity and origin of abyssal tholeiite from the Mid-Atlantic Ridge near $24^{\circ}$ and $30^{\circ}$ north latitude, Contrib. Mineral. Petrol., v. 23, p. 38-52.

, 1970. Crystallization and differentiation in abyssal tholeiites and gabbros from Mid-oceanic ridges, Earth Planet. Sci. Lett., v. 7, p. 361-365. 


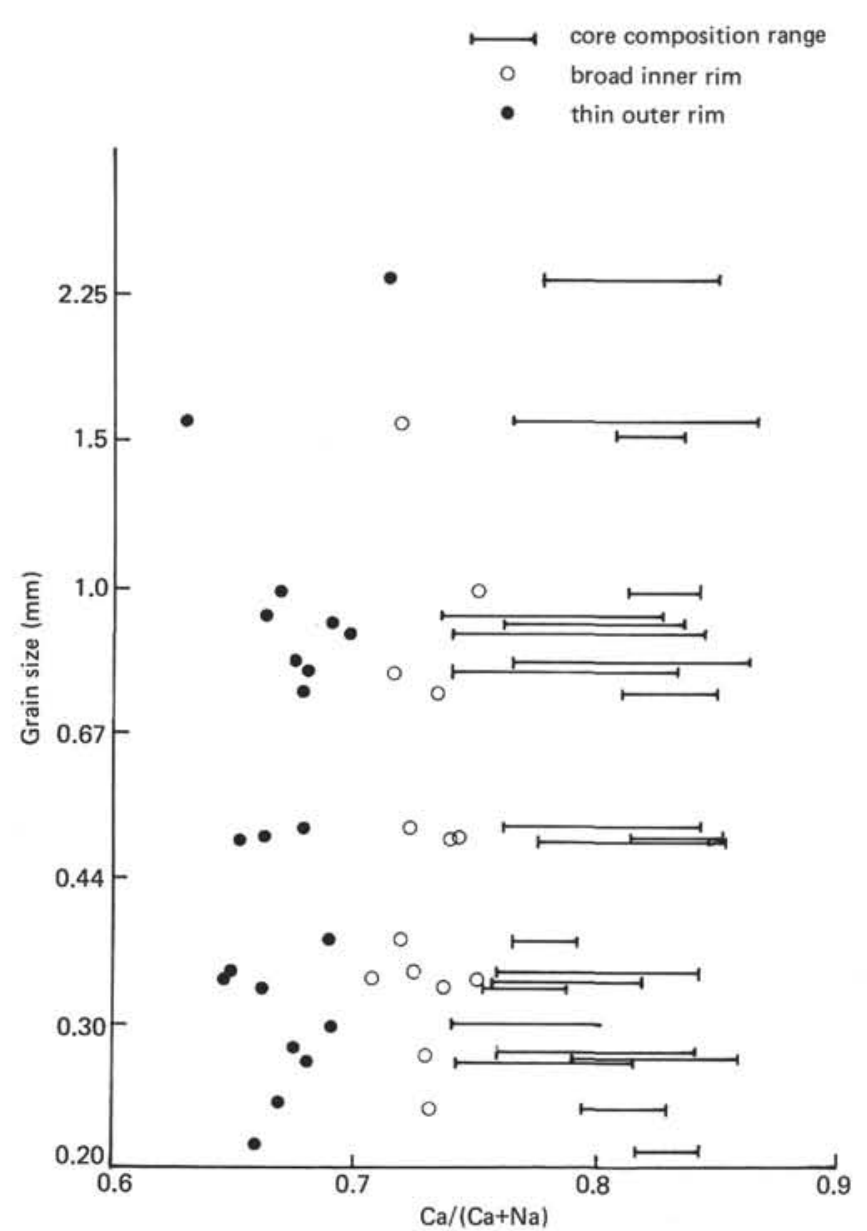

Figure 17. Composition of plagioclase phenocryst in phyric basalt Sample 18-1, 132-142 cm (\#7F).

Moore, J.G. and Evans, B.W., 1967. The role of olivine in the crystallization of the prehistoric Makaopuhi tholeiitic lava lake, Contrib. Mineral. Petrol., v. 15, p. 202-223.

Moore, J.G. and Shilling, J.G., 1973. Vesicles, water, and sulfer in Reykjanes ridge basalts, Contrib. Mineral. Petrol., v. 41, p. 105-118.

Nicholls, I. and Ringwood, A.E., 1973. Effect of water on olivine stability in tholeiites and the production of silica-saturated magmas in the island-arc environment, J. Geol., v. 81, p. 285-300.

Roeder, P.L. and Emslie, R.F., 1970. Olivine-liquid equilibrium, Contrib. Mineral. Petrol., v. 29, p. 304-325.

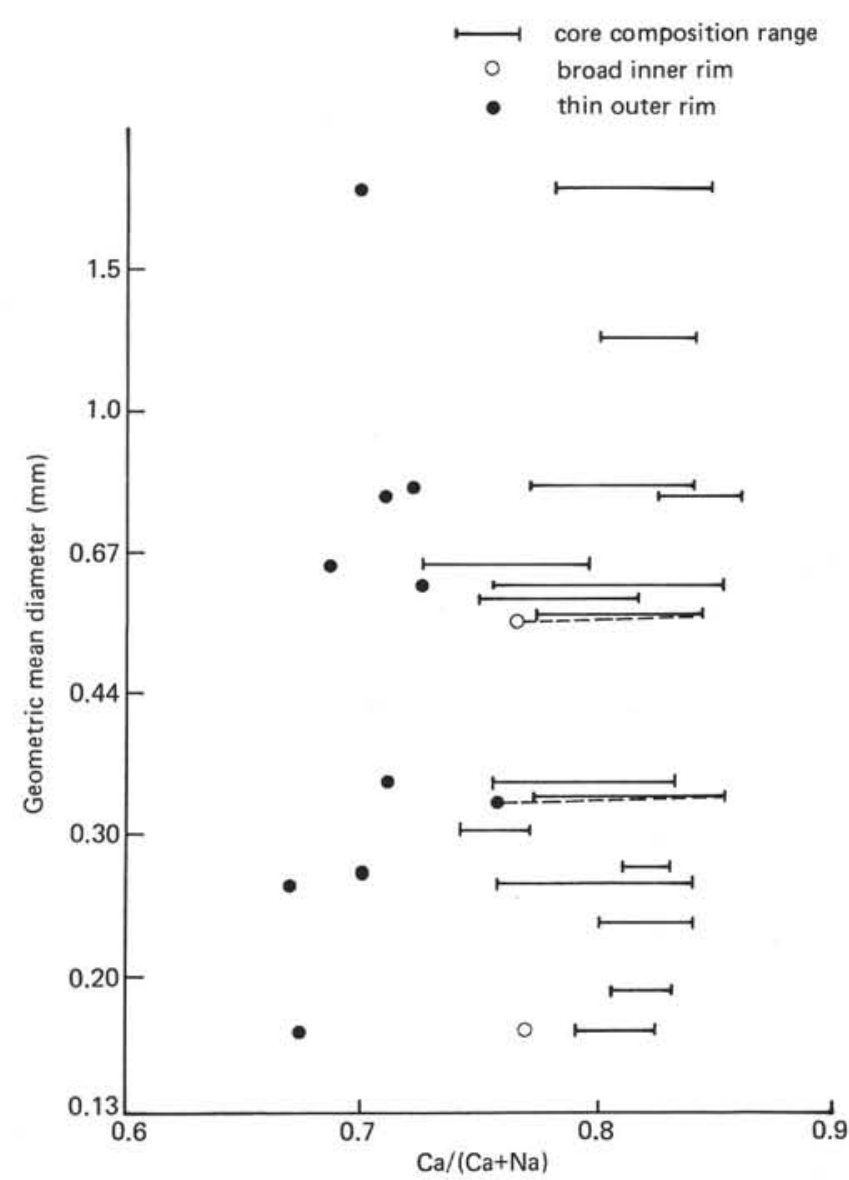

Figure 18. Composition of plagioclase phenocryst in phyric basalt Sample 22-1, 104-106 cm (\#13).

Sato, H., 1970. Nickel content of basaltic magmas: identification of primary magmas and a measure of the degree of olivine fractionation, Lithos, v. 10, p. 113-120.

Shibata, T., 1976. Phenocryst-bulk rock composition relations of abyssal tholeiites and their petrogenetic significance, Geochim, Cosmochim. Acta., v. 40, p. 1407-1417.

Shido, F., Miyashiro, A., and Ewing, M., 1972. Compositional variation in pillow lavas from the Mid-Atlantic Ridge, Mar. Geol., v. 16, p. 177-190.

Sigurdsson, H. and Schilling, J.G., 1975. Spinels in Mid-Atlantic Ridge basalts: chemistry and occurrence, Earth Planet. Sci. Lett., v. 29 , p. 7-20.

Walker, D., Kirkpatrick, R.J., Longhi, J., and Hays, J.F., 1976. Crystallization history of lunar picritic basalt sample 12002: Phase-equilibria and cooling-rate studies, Geol. Soc. Am. Bull., v. 87 , p. 646-656. 
- groundmass plagioclase core (max. An)

- Compositional range of phenocrysts plagioclase core

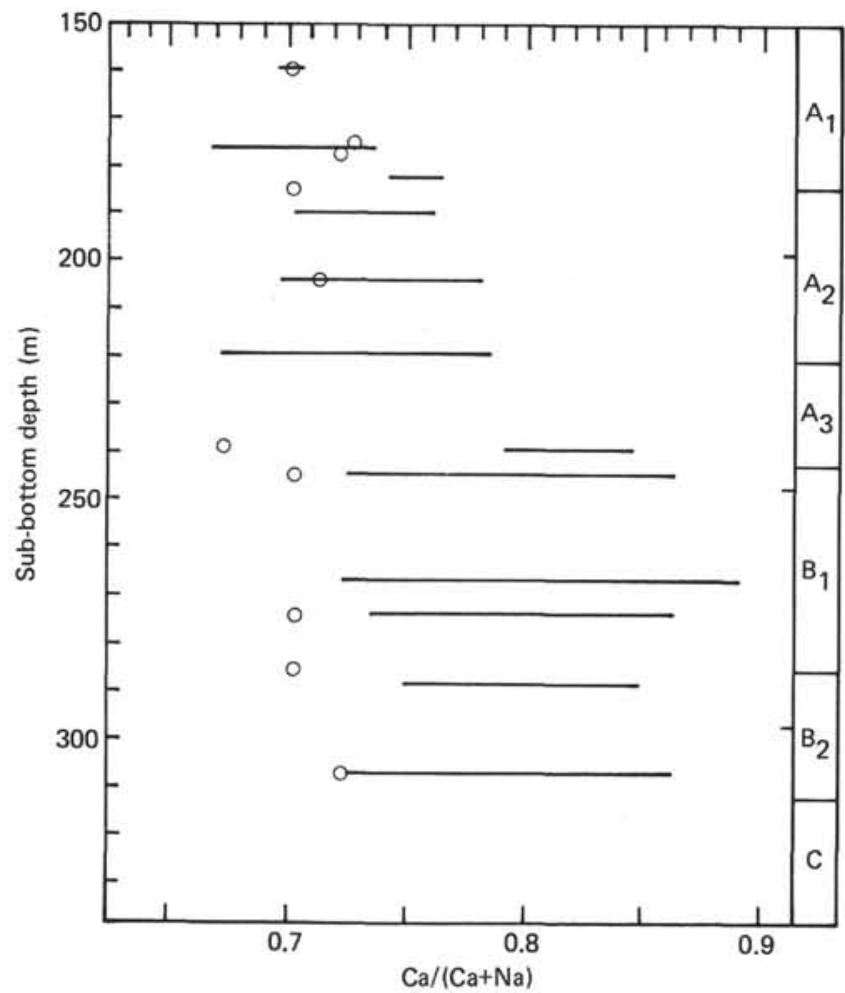

Figure 19. Stratigraphic variation of the composition of plagioclase phenocryst in Hole 396B.

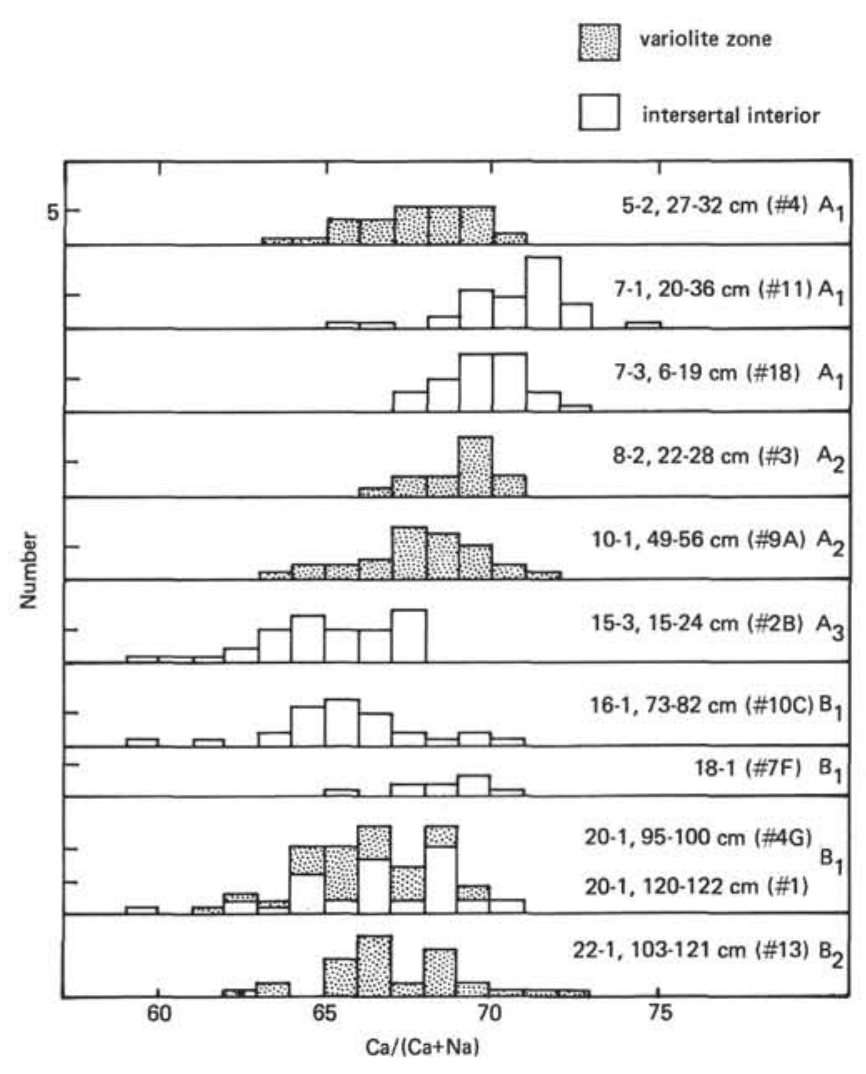

Figure 20. Stratigraphic variation of the composition of groundmass plagioclase in Hole $396 B$. 
TABLE 7

Chromian Spinel Composition

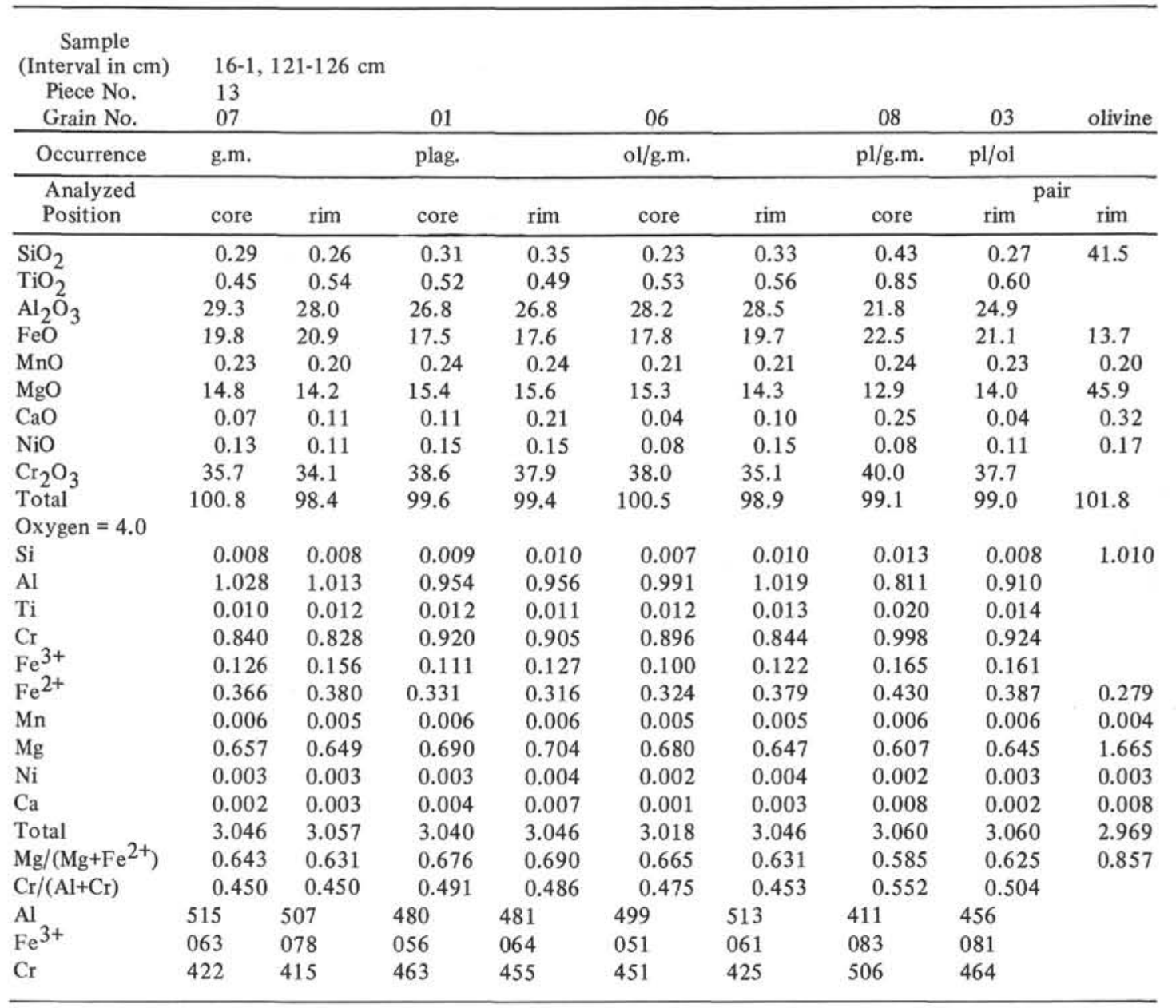

Sample

(Interval in cm) 22-1, 105-121 cm

Piece No. 13

$\begin{array}{llllll}\text { Grain No. } & 06 & 07 & 01 & 05 & 02\end{array}$

\begin{tabular}{|c|c|c|c|c|c|c|c|c|}
\hline Occurrence & ol/g.m. & ol/g.m. & plag. & & pl/g.m. & & g.m. & \\
\hline $\begin{array}{l}\text { Analyzed } \\
\text { Position }\end{array}$ & core & core & core & rim & core & rim & core & rim \\
\hline $\mathrm{TiO}_{2}$ & 23.95 & 27.35 & 31.43 & 31.49 & 29.86 & 27.59 & 26.86 & 26.17 \\
\hline $\mathrm{FeO}$ & 19.13 & 18.67 & 16.97 & 16.52 & 17.82 & 18.09 & 18.71 & 18.93 \\
\hline $\mathrm{MnO}$ & 0.19 & 0.22 & 0.13 & 0.15 & 0.18 & 0.18 & 0.19 & 0.14 \\
\hline $\mathrm{MgO}$ & 14.36 & 15.50 & 16.63 & 16.59 & 15.08 & 14.08 & 14.95 & 14.92 \\
\hline $\mathrm{Cr}_{2} \mathrm{O}_{3}$ & 39.55 & 37.61 & 35.32 & 34.96 & 35.05 & 36.09 & 37.39 & 37.11 \\
\hline $\begin{array}{l}\text { Total } \\
\text { Oxygen }=4.0\end{array}$ & 97.84 & 99.88 & 100.95 & 100.21 & 98.45 & 96.59 & 98.68 & 97.88 \\
\hline $\mathrm{Al}$ & 0.883 & 0.972 & 1.079 & 1.087 & 1.062 & 1.011 & 0.968 & 0.954 \\
\hline $\mathrm{Ti}$ & 0.016 & 0.012 & 0.010 & 0.011 & 0.011 & 0.013 & 0.013 & 0.014 \\
\hline $\mathrm{Cr}$ & 0.979 & 0.897 & 0.814 & 0.810 & 0.836 & 0.887 & 0.904 & 0.907 \\
\hline $\mathrm{Fe}^{2+}$ & 0.359 & 0.327 & 0.298 & 0.296 & 0.343 & 0.368 & 0.343 & 0.341 \\
\hline $\mathrm{Fe}^{3+}$ & 0.142 & 0.144 & 0.116 & 0.109 & 0.107 & 0.102 & 0.136 & 0.149 \\
\hline Mn & 0.005 & 0.006 & 0.003 & 0.004 & 0.004 & 0.005 & 0.005 & 0.004 \\
\hline $\mathrm{Mg}$ & 0.670 & 0.697 & 0.723 & 0.725 & 0.678 & 0.653 & 0.682 & 0.688 \\
\hline Total & 2.054 & 3.055 & 3.043 & 3.042 & 3.041 & 3.039 & 3.051 & 3.057 \\
\hline $\mathrm{Mg} /\left(\mathrm{Mg}+\mathrm{Fe}^{2+}\right)$ & 0.651 & 0.680 & 0.708 & 0.710 & 0.664 & 0.640 & 0.665 & 0.669 \\
\hline $\mathrm{Cr} /(\mathrm{Al}+\mathrm{Cr})$ & 0.526 & 0.480 & 0.430 & 0.427 & 0.440 & 0.467 & 0.483 & 0.487 \\
\hline $\mathrm{Al}$ & 441 & 483 & 537 & 542 & 530 & 506 & 482 & 475 \\
\hline $\mathrm{Fe}^{3+}$ & 071 & 072 & 058 & 054 & 053 & 051 & 068 & 074 \\
\hline $\mathrm{Cr}$ & 489 & 446 & 405 & 404 & 417 & 444 & 450 & 451 \\
\hline
\end{tabular}


TABLE 7 - Continued

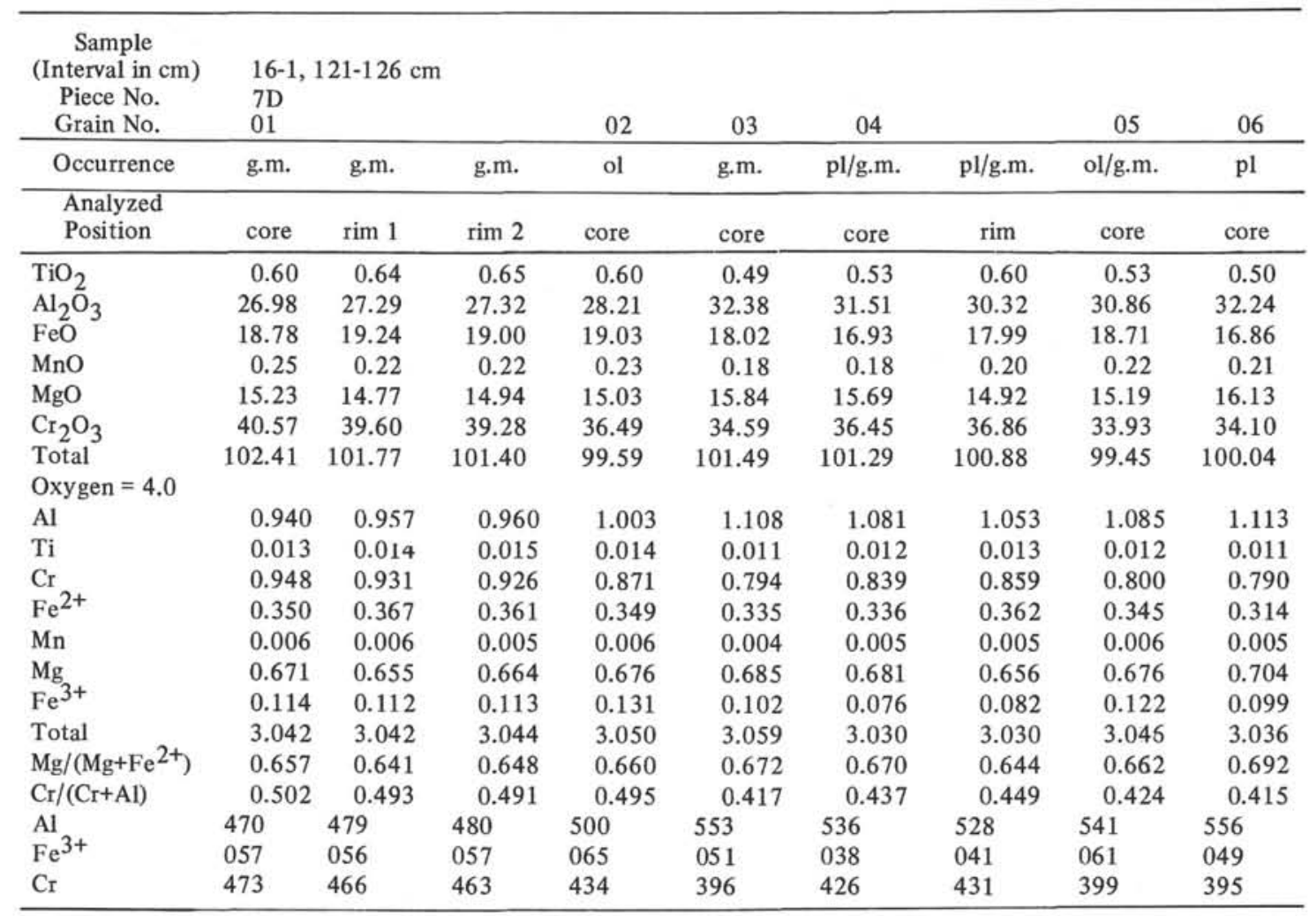

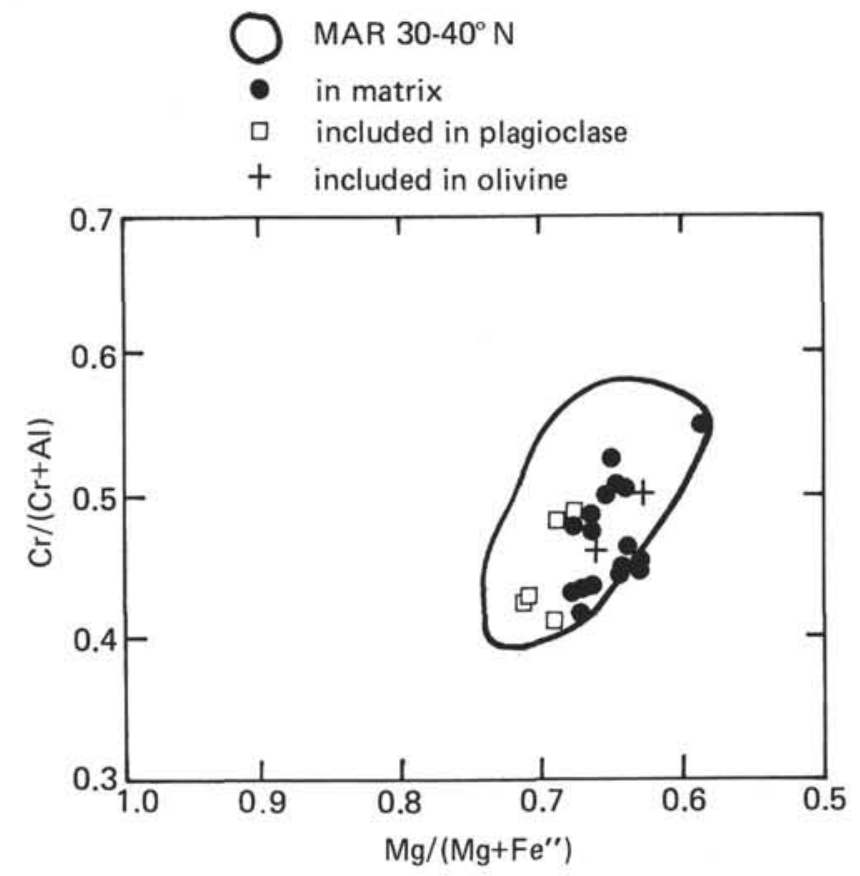

Figure 21. Composition of chromian spinel in phyric basalts of Samples 16-1, 75-80 cm (\#10C); 22-1, 104$106 \mathrm{~cm}$ (\#13); and 22-2, 125-146 cm (\#7D). 
TABLE 8

Bulk Rock Analyses of IPOD Leg 46, Hole 396B Basalt

\begin{tabular}{|c|c|c|c|c|c|c|c|c|c|c|c|c|c|c|c|}
\hline $\begin{array}{c}\text { Sample } \\
\text { (Interval in cm) } \\
\text { Piece No. }\end{array}$ & $\begin{array}{c}4-1, \\
126-132 \\
12\end{array}$ & $\begin{array}{c}6-1 \\
52-60 \\
7 \\
\end{array}$ & $\begin{array}{c}7-1 \\
50-54 \\
7 \\
\end{array}$ & $\begin{array}{c}7-1 \\
116-130 \\
11\end{array}$ & $\begin{array}{c}7-3 \\
6-20 \\
18 \\
\end{array}$ & $\begin{array}{c}8-1 \\
60-67 \\
18 \mathrm{~A}\end{array}$ & $\begin{array}{c}9-1 \\
118-124 \\
15 B\end{array}$ & $\begin{array}{c}10-1 \\
48-53 \\
9 \mathrm{~A}\end{array}$ & $\begin{array}{c}10-1 \\
48-53 \\
9 \mathrm{~A}^{\mathrm{a}} \\
\end{array}$ & $\begin{array}{c}11-1 \\
110-117 \\
12\end{array}$ & $\begin{array}{c}12-1 \\
126-133 \\
8 \\
\end{array}$ & $\begin{array}{l}13-2 \\
37-45 \\
5 \mathrm{~A}\end{array}$ & $\begin{array}{c}13-3, \\
7-15 \\
1\end{array}$ & $\begin{array}{c}14-3 \\
58-60 \\
5 \mathrm{~A}\end{array}$ & $\begin{array}{c}12-1 \\
120-133 \\
2 C^{\mathrm{a}}\end{array}$ \\
\hline $\mathrm{SiO}_{2}$ & 49.74 & 49.22 & 48.91 & 48.98 & 48.57 & 49.15 & 48.78 & 49.46 & 50.41 & 48.62 & 48.06 & 49.16 & 48.75 & 48.66 & 48.86 \\
\hline $\mathrm{TiO}_{2}$ & 1.49 & 1.49 & 1.41 & 1.50 & 1.45 & 1.58 & 1.63 & 1.67 & 1.60 & 1.62 & 1.58 & 1.64 & 1.72 & 1.69 & 1.75 \\
\hline $\mathrm{Al}_{2} \ddot{\mathrm{O}}_{3}$ & 15.38 & 15.32 & 15.49 & 15.47 & 15.46 & 14.64 & 14.69 & 15.40 & 15.34 & 15.18 & 15.42 & 15.33 & 15.11 & 15.07 & 15.11 \\
\hline $\mathrm{Fe}_{2} \mathrm{O}_{3}$ & 2.24 & 3.11 & 3.81 & 3.11 & 2.83 & 3.77 & 3.74 & 3.12 & 1.09 & 3.67 & 4.44 & 2.81 & 4.49 & 3.04 & 2.75 \\
\hline $\mathrm{FeO}$ & 7.17 & 5.40 & 5.30 & 6.54 & 6.24 & 6.11 & 5.54 & 7.04 & 8.79 & 6.46 & 5.29 & 6.97 & 5.12 & 6.48 & 7.26 \\
\hline MnO & 0.17 & 0.15 & 0.16 & 0.17 & 0.16 & 0.17 & 0.19 & 0.17 & 0.18 & 0.18 & 0.19 & 0.17 & 0.15 & 0.17 & 0.16 \\
\hline $\mathrm{MgO}$ & 7.67 & 7.38 & 7.86 & 7.71 & 8.25 & 7.90 & 7.26 & 7.46 & 8.20 & 7.79 & 7.46 & 7.75 & 6.90 & 7.38 & 7.88 \\
\hline $\mathrm{CaO}$ & 11.36 & 11.90 & 11.10 & 11.76 & 11.64 & 11.03 & 11.49 & 11.15 & 11.06 & 11.12 & 10.89 & 11.08 & 10.66 & 11.61 & 10.49 \\
\hline $\mathrm{Na}_{2} \mathrm{O}$ & 2.61 & 2.68 & 2.59 & 2.41 & 2.61 & 2.57 & 2.65 & 2.69 & 2.71 & 2.71 & 2.74 & 2.73 & 2.89 & 2.89 & 2.82 \\
\hline $\mathrm{K}_{2} \mathrm{O}$ & 0.16 & 0.24 & 0.23 & 0.24 & 0.22 & 0.28 & 0.28 & 0.19 & 0.13 & 0.22 & 0.31 & 0.22 & 0.30 & 0.33 & 0.18 \\
\hline $\mathrm{P}_{2} \mathrm{O}_{5}$ & 0.15 & 0.15 & 0.16 & 0.15 & 0.15 & 0.16 & 0.16 & 0.16 & & 0.16 & 0.16 & 0.15 & 0.16 & 0.16 & 0.18 \\
\hline $\mathrm{H}_{2} \mathrm{O}(+)$ & 1.03 & 1.45 & 1.39 & 1.25 & 1.37 & 1.31 & 1.36 & 0.92 & & 1.30 & 1.94 & 1.26 & 2.08 & 1.89 & 1.49 \\
\hline $\mathrm{H}_{2} \mathrm{O}(-)$ & 0.44 & 1.36 & 1.47 & 0.65 & 1.10 & 1.31 & 1.57 & 0.59 & & 1.00 & 1.33 & 0.66 & 1.86 & 0.57 & 1.18 \\
\hline Total & 99.61 & 99.85 & 99.88 & 99.94 & 100.05 & 99.98 & 99.34 & 100.02 & 99.51 & 100.03 & 99.81 & 99.93 & 100.19 & 99.94 & 110.11 \\
\hline Qz & & 0.56 & 1.06 & 0.22 & & 1.18 & 1.36 & 0.30 & & & 0.42 & & 2.05 & & \\
\hline Or & 0.96 & 1.46 & 1.40 & 1.45 & 1.33 & 1.70 & 1.72 & 1.14 & 0.77 & 1.33 & 1.90 & 1.33 & 1.84 & 2.00 & 1.09 \\
\hline $\mathrm{Ab}$ & 22.50 & 23.37 & 22.59 & 20.80 & 22.63 & 22.34 & 23.26 & 23.11 & 23.04 & 23.46 & 24.01 & 23.57 & 25.41 & 25.09 & 24.49 \\
\hline $\mathrm{An}$ & 30.34 & 29.95 & 30.88 & 31.30 & 30.56 & 28.33 & 28.38 & 29.83 & 29.45 & 29.27 & 29.89 & 29.51 & 28.44 & 27.87 & 28.77 \\
\hline Wo & 10.90 & 12.48 & 10.36 & 11.37 & 11.54 & 11.20 & 12.39 & 10.55 & 10.73 & 10.91 & 10.44 & 10.68 & 10.62 & 12.59 & 9.79 \\
\hline En & 19.32 & 18.94 & 20.18 & 19.59 & 16.56 & 20.21 & 18.76 & 18.86 & 15.65 & 18.70 & 19.25 & 17.86 & 17.86 & 14.46 & 17.87 \\
\hline$F_{5}$ & 9.27 & 5.32 & 4.69 & 7.42 & 5.66 & 5.97 & 4.92 & 8.03 & 9.91 & 6.25 & 3.93 & 7.48 & 3.25 & 5.44 & 7.71 \\
\hline Fo & 0.11 & & & & 3.15 & & & & 3.41 & 0.81 & & 1.28 & & 3.08 & 1.59 \\
\hline $\mathrm{Fa}$ & 0.06 & & & & 1.19 & & & & 2.38 & 0.30 & & 0.59 & & 1.28 & 0.76 \\
\hline Mt - & 3.31 & 4.65 & 5.69 & 4.60 & 4.20 & 5.61 & 5.62 & 4.59 & 1.59 & 5.44 & 6.67 & 4.16 & 6.76 & 4.52 & 4.09 \\
\hline $\mathrm{IIm}$ & 2.88 & 2.92 & 2.76 & 2.91 & 2.82 & 3.08 & 3.21 & 3.22 & 3.05 & 3.15 & 3.11 & 3.18 & 3.39 & 3.29 & 3.41 \\
\hline Apat & 0.35 & 0.36 & 0.38 & 0.35 & 0.36 & 0.38 & 0.38 & 0.38 & & 0.38 & 0.38 & 0.35 & 0.39 & 0.38 & 0.43 \\
\hline Oxidation Index & 0.219 & 0.341 & 0.393 & 0.300 & 0.290 & 0.357 & 0.378 & 0.285 & 0.100 & 0.338 & 0.430 & 0.266 & 0.441 & 0.297 & 0.259 \\
\hline Mg-value & 0.656 & 0.709 & 0.726 & 0.678 & 0.702 & 0.697 & 0.700 & 0.654 & 0.625 & 0.683 & 0.715 & 0.665 & 0.706 & 0.670 & 0.659 \\
\hline Mg-value ${ }^{a}$ & 0.623 & 0.641 & 0.641 & 0.621 & 0.650 & 0.622 & 0.618 & 0.600 & 0.624 & 0.613 & 0.614 & 0.618 & 0.599 & 0.613 & 0.616 \\
\hline
\end{tabular}

analyses of separated fresh glass.

TABLE 9

Glass Analyses of IPOD Leg 46, Hole 396B Basalt

\begin{tabular}{|c|c|c|c|c|c|c|c|c|c|c|c|}
\hline $\begin{array}{c}\text { Sample } \\
\text { (Interval in } \mathrm{cm} \text { ) }\end{array}$ & $\begin{array}{c}4-1 \\
126-132\end{array}$ & $\begin{array}{l}5-1 \\
85-91\end{array}$ & $\begin{array}{r}5-2 \\
27-33\end{array}$ & $\begin{array}{c}7-2, \\
93-102\end{array}$ & $\begin{array}{r}8-2 \\
22-23\end{array}$ & $\begin{array}{c}\text { 9-1, } \\
23-26\end{array}$ & $\begin{array}{r}10-1, \\
48-53\end{array}$ & $\begin{array}{r}11-1, \\
55-59\end{array}$ & $\begin{array}{r}11-2, \\
37-39\end{array}$ & $\begin{array}{r}13-1, \\
35-40\end{array}$ & $\begin{array}{r}13-2, \\
37-45\end{array}$ \\
\hline Piece No. & 12 & 9 & 4 & 9 & 3 & 5 & 9 & 6 & 4 & 4 & 5 \\
\hline $\mathrm{SiO}_{2}$ & 50.6 & 51.3 & 51.2 & 50.6 & 50.7 & 51.3 & 50.6 & 51.7 & 51.0 & 51.0 & 50.6 \\
\hline $\mathrm{TiO}_{2}^{2}$ & 1.35 & 1.43 & 1.40 & 1.40 & 1.51 & 1.51 & 1.54 & 1.49 & 1.51 & 1.49 & 1.44 \\
\hline $\mathrm{Al}_{2} \mathrm{O}_{3}$ & 15.6 & 15.6 & 15.5 & 15.4 & 15.5 & 16.0 & 15.5 & 15.4 & 15.6 & 15.5 & 15.4 \\
\hline $\mathrm{FeO}$ & 9.10 & 9.18 & 9.27 & 8.99 & 9.51 & 9.45 & 9.59 & 9.57 & 9.61 & 9.58 & 9.60 \\
\hline $\mathrm{MnO}$ & 0.18 & 0.17 & 0.15 & 0.13 & 0.16 & 0.16 & 0.17 & 0.16 & 0.18 & 0.16 & 0.14 \\
\hline $\mathrm{MgO}$ & 8.45 & 8.57 & 8.48 & 8.47 & 8.06 & 8.20 & 8.08 & 8.02 & 8.15 & 8.14 & 8.01 \\
\hline $\mathrm{CaO}$ & 11.43 & 11.40 & 11.40 & 11.43 & 11.29 & 11.02 & 11.27 & 11.32 & 11.15 & 11.13 & 11.14 \\
\hline $\mathrm{Na}_{2} \mathrm{O}$ & 2.70 & 2.77 & 2.76 & 2.83 & 2.85 & 2.75 & 2.82 & 2.77 & 2.81 & 2.83 & 2.84 \\
\hline $\mathrm{K}_{2} \mathrm{O}$ & 0.10 & 0.10 & 0.10 & 0.10 & 0.10 & 0.11 & 0.12 & 0.12 & 0.12 & 0.12 & 0.11 \\
\hline Total & 99.5 & 100.5 & 100.3 & 99.4 & 99.7 & 100.4 & 99.7 & 100.5 & 100.1 & 99.9 & 99.3 \\
\hline Or & 0.59 & 0.59 & 0.59 & 0.59 & 0.59 & 0.65 & 0.71 & 0.70 & 0.71 & 0.71 & 0.65 \\
\hline $\mathrm{Ab}$ & 22.94 & 23.29 & 23.26 & 24.06 & 24.17 & 23.14 & 23.91 & 23.30 & 23.72 & 23.94 & 24.17 \\
\hline An & 30.21 & 29.57 & 29.56 & 29.27 & 29.24 & 30.74 & 29.23 & 28.97 & 29.45 & 29.20 & 29.20 \\
\hline Wo & 11.16 & 11.13 & 11.18 & 11.57 & 11.23 & 9.87 & 11.19 & 11.22 & 10.75 & 10.86 & 11.02 \\
\hline En & 15.51 & 16.18 & 16.11 & 14.56 & 14.60 & 16.75 & 14.57 & 17.41 & 15.53 & 15.42 & 14.77 \\
\hline Fs & 9.07 & 9.31 & 9.48 & 8.25 & 9.20 & 10.29 & 9.25 & 11.13 & 9.82 & 9.73 & 9.52 \\
\hline Fo & 3.94 & 3.53 & 3.45 & 4.65 & 3.87 & 2.50 & 3.91 & 1.71 & 3.31 & 3.40 & 3.71 \\
\hline $\mathrm{Fa}$ & 2.54 & 2.24 & 2.24 & 2.91 & 2.69 & 1.69 & 2.73 & 1.21 & 2.31 & 2.36 & 2.64 \\
\hline II & 2.57 & 2.70 & 2.65 & 2.67 & 2.87 & 2.85 & 2.93 & 2.81 & 2.86 & $2.83]$ & 2.75 \\
\hline Mt & 1.47 & 1.47 & 1.49 & 1.45 & 1.53 & 1.51 & 1.55 & 1.53 & 1.54 & 1.54 & 1.55 \\
\hline Mg-value & 0.648 & 0.649 & 0.644 & 0.651 & 0.627 & 0.632 & 0.625 & 0.624 & 0.627 & 0.627 & 0.623 \\
\hline
\end{tabular}


TABLE 8 - Continued

\begin{tabular}{|c|c|c|c|c|c|c|c|c|c|c|c|c|}
\hline $\begin{array}{c}15 \cdot 3 \\
15 \cdot 23 \\
2 B\end{array}$ & $\begin{array}{c}15-4 \\
112-116 \\
7 \mathrm{~A}\end{array}$ & $\begin{array}{c}15-5 \\
29-3 \mathrm{i} \\
3\end{array}$ & $\begin{array}{l}16-1 \\
72-81 \\
10 C\end{array}$ & $\begin{array}{c}17-1 \\
18-26 \\
2 \mathrm{~A}\end{array}$ & $\begin{array}{c}18-1 \\
132-142 \\
7 \mathrm{~F}\end{array}$ & $\begin{array}{c}20-1 \\
90-101 \\
4 \mathrm{G}\end{array}$ & $\begin{array}{c}20-6 \\
44-53 \\
6\end{array}$ & $\begin{array}{c}21-1 \\
69-79 \\
9\end{array}$ & $\begin{array}{c}22-1 \\
111-122 \\
13\end{array}$ & $\begin{array}{c}22-1 \\
111-122 \\
13^{b}\end{array}$ & $\begin{array}{c}22-3 \\
28-37 \\
2 \mathrm{~A}\end{array}$ & $\begin{array}{c}32-1 \\
77-81 \\
11\end{array}$ \\
\hline 48.81 & 48.94 & 48.91 & 48.53 & 48.28 & 49.01 & 48.53 & 48.59 & 48.33 & 47.41 & 47.94 & 48.27 & 49.04 \\
\hline 1.73 & 1.68 & 1.71 & 1.30 & 1.25 & 1.24 & 1.20 & 1.01 & 1.04 & 1.06 & 1.33 & 1.65 & 1.59 \\
\hline 15.17 & 14.82 & 15.23 & 16.83 & 16.99 & 16.61 & 17.00 & 18.02 & 17.42 & 17.26 & 15.76 & 17.30 & 16.26 \\
\hline 2.70 & 2.56 & 3.53 & 3.79 & 3.55 & 2.50 & 3.43 & 2.94 & 3.47 & 3.49 & 3.78 & 3.20 & 3.44 \\
\hline 7.22 & 7.58 & 6.30 & 4.99 & 5.04 & 6.03 & 4.89 & 4.49 & 4.40 & 4.56 & 5.63 & 4.08 & 6.12 \\
\hline 0.16 & 0.14 & 0.13 & 0.20 & 0.11 & 0.14 & 0.13 & 0.13 & 0.13 & & & 0.14 & 0.16 \\
\hline 7.89 & 7.44 & 7.70 & 7.02 & 7.44 & 7.67 & 7.31 & 7.58 & 7.59 & 7.97 & 7.36 & 7.81 & 6.83 \\
\hline 10.49 & 10.58 & 10.53 & 11.83 & 11.77 & 11.64 & 11.78 & 12.26 & 12.17 & 11.61 & 11.72 & 11.99 & 11.45 \\
\hline 2.79 & 2.79 & 2.78 & 2.51 & 2.55 & 2.50 & 2.49 & 2.45 & 2.52 & 2.34 & 2.43 & 2.35 & 2.91 \\
\hline 0.15 & 0.18 & 0.21 & 0.20 & 0.22 & 0.10 & 0.21 & 0.18 & 0.20 & 0.12 & 0.12 & 0.23 & 0.39 \\
\hline 0.13 & 0.17 & 0.14 & 0.12 & 0.11 & 0.12 & 0.12 & 0.10 & 0.10 & 0.13 & 0.13 & 0.14 & 0.16 \\
\hline 1.62 & 1.21 & 1.50 & 1.29 & 1.26 & 1.21 & 1.40 & 0.91 & 1.07 & 2.41 & 2.61 & 1.58 & 0.86 \\
\hline 1.12 & 1.37 & 1.43 & 1.33 & 1.50 & 1.37 & 1.41 & 1.45 & 1.60 & 1.65 & 1.39 & 1.09 & 0.82 \\
\hline \multirow[t]{2}{*}{99.98} & 99.46 & 100.10 & 99.94 & 100.07 & 100.14 & 99.90 & 100.11 & 100.04 & 100.01 & 100.20 & 99.83 & 100.03 \\
\hline & & 0.47 & 0.92 & & & 0.42 & & & & 0.89 & 0.59 & \\
\hline 0.91 & 1.10 & 1.28 & 1.21 & 1.34 & 0.61 & 1.28 & 1.09 & 1.21 & 0.74 & 0.74 & 1.40 & 2.34 \\
\hline 24.28 & 24.37 & 24.21 & 21.82 & 22.17 & 21.68 & 21.70 & 21.21 & 21.90 & 21.64 & 21.37 & 20.47 & 25.04 \\
\hline 29.23 & 28.26 & 29.29 & 35.00 & 35.21 & 34.65 & 35.62 & 38.50 & 36.59 & 37.77 & 32.99 & 37.03 & 30.66 \\
\hline 9.78 & 10.35 & 9.83 & 10.23 & 10.05 & 9.92 & 9.93 & 9.63 & 10.34 & 8.93 & 11.10 & 9.72 & 10.88 \\
\hline 18.11 & 18.34 & 19.74 & 17.97 & 17.95 & 18.93 & 18.75 & 17.06 & 17.30 & 19.68 & 19.06 & 20.02 & 14.94 \\
\hline 7.80 & 9.20 & 6.25 & 4.37 & 4.32 & 7.16 & 4.54 & 3.97 & 3.42 & 3.71 & 5.22 & 2.45 & 5.33 \\
\hline 1.47 & 0.55 & & & 0.77 & 0.46 & & 1.58 & 1.48 & 0.71 & & & 1.65 \\
\hline 0.70 & 0.30 & & & 0.20 & 0.19 & & 0.41 & 0.32 & 0.15 & & & 0.65 \\
\hline 4.03 & 3.83 & 5.27 & 5.65 & 5.29 & 3.72 & 5.12 & 4.36 & 5.17 & 5.27 & 5.70 & 4.78 & 5.07 \\
\hline 3.38 & 3.29 & 3.34 & 2.54 & 2.44 & 2.41 & 2.35 & 1.96 & 2.03 & 2.10 & 2.63 & 3.23 & 3.07 \\
\hline 0.31 & 0.41 & 0.33 & 0.29 & 0.26 & 0.28 & 0.29 & 0.24 & 0.24 & 0.31 & 0.31 & 0.33 & 0.38 \\
\hline 0.252 & 0.233 & 0.335 & 0.406 & 0.388 & 0.272 & 0.371 & 0.387 & 0.415 & 0.408 & 0.377 & 0.414 & 0.336 \\
\hline 0.661 & 0.636 & 0.685 & 0.715 & 0.725 & 0.694 & 0.751 & 0.727 & 0.755 & 0.757 & 0.700 & 0.773 & 0.666 \\
\hline 0.618 & 0.599 & 0.617 & 0.623 & 0.642 & 0.47 & 0.645 & 0.678 & 0.667 & 0.672 & 0.617 & 0.690 & 0.595 \\
\hline
\end{tabular}

TABLE 9 - Continued

\begin{tabular}{|c|c|c|c|c|c|c|c|c|c|c|c|c|}
\hline $\begin{array}{l}14-1, \\
3-6\end{array}$ & $\begin{array}{c}15-1 \\
37-43\end{array}$ & $\begin{array}{c}16-2 \\
125-132\end{array}$ & $\begin{array}{c}16-3, \\
\cdot \quad 130-137\end{array}$ & $\begin{array}{c}17-2 \\
17-25\end{array}$ & $\begin{array}{c}18-2 \\
81-90\end{array}$ & $\begin{array}{l}21-1 \text {, } \\
80-90\end{array}$ & $\begin{array}{l}20-2 \\
3-10\end{array}$ & $\begin{array}{c}20-2 \\
136-140\end{array}$ & $\begin{array}{r}21-2 \\
37-44\end{array}$ & $\begin{array}{c}22-1, \\
111-122\end{array}$ & $\begin{array}{c}24-1 \\
19-24\end{array}$ & $\begin{array}{c}32-1 \\
77-81\end{array}$ \\
\hline 1 & 6 & 4 & 15 & 2 & 4 & $4 \mathrm{~F}$ & 1 & 9 & 4 & 13 & 4 & 11 \\
\hline 50.2 & 50.9 & 50.8 & 51.0 & 50.7 & 51.1 & 50.6 & 51.5 & 51.1 & 50.6 & 51.0 & 51.1 & 50.6 \\
\hline 1.64 & 1.66 & 1.34 & 1.44 & 1.47 & 1.37 & 1.35 & 1.32 & 1.25 & 1.28 & 1.23 & 1.50 & 1.52 \\
\hline 15.4 & 15.7 & 15.2 & 15.4 & 15.3 & 15.3 & 15.3 & 15.5 & 15.4 & 15.5 & 15.8 & 16.5 & 16.2 \\
\hline 10.20 & 9.97 & 9.43 & 9.56 & 9.59 & 9.44 & 9.39 & 9.23 & 9.04 & 8.95 & 8.53 & 9.03 & 9.13 \\
\hline 0.17 & 0.17 & 0.16 & 0.16 & 0.17 & 0.23 & 0.16 & 0.17 & 0.19 & 0.16 & 0.18 & 0.14 & 0.17 \\
\hline 7.79 & 7.70 & 8.01 & 7.90 & 7.87 & 7.92 & 7.89 & 8.00 & 8.23 & 8.31 & 8.32 & 8.22 & 8.06 \\
\hline 10.60 & 10.87 & 11.56 & 11.58 & 11.57 & 11.66 & 11.50 & 11.69 & 11.94 & 12.06 & 12.4 & 11.31 & 11.12 \\
\hline 3.12 & 3.12 & 2.80 & 2.77 & 2.65 & 2.78 & 2.79 & 2.84 & 2.70 & 2.65 & 2.71 & 3.03 & 2.97 \\
\hline 0.11 & 0.11 & 0.10 & 0.12 & 0.12 & 0.10 & 0.10 & 0.09 & 0.11 & 0.09 & 0.11 & 0.17 & 0.15 \\
\hline 99.2 & 100.2 & 99.3 & 99.9 & 99.4 & 99.9 & 99.1 & 100.3 & 100.0 & 99.6 & 100.2 & 100.9 & 100.0 \\
\hline 0.65 & 0.65 & 0.59 & 0.17 & 0.7 & 0.6 & 0.6 & 0.5 & 0.7 & 0.5 & 0.7 & 1.0 & 0.9 \\
\hline 26.58 & 26.32 & 23.83 & 23.43 & 22.5 & 23.5 & 23.8 & 23.9 & 22.8 & 22.5 & 22.9 & 25.4 & 25.1 \\
\hline 27.85 & 28.31 & 28.72 & 29.17 & 29.7 & 28.9 & 29.3 & 29.1 & 29.6 & 30.2 & 30.4 & 30.5 & 30.5 \\
\hline 10.48 & 10.63 & 12.10 & 11.81 & 11.7 & 12.1 & 11.8 & 12.0 & 12.4 & 12.5 & 13.0 & 10.5 & 10.3 \\
\hline 11.86 & 12.84 & 14.99 & 15.43 & 16.2 & 15.6 & 15.0 & 15.7 & 15.7 & 14.9 & 14.1 & 12.0 & 12.7 \\
\hline 8.27 & 8.80 & 9.62 & 10.07 & 10.6 & 10.2 & 9.7 & 9.9 & 9.5 & 8.7 & 7.9 & 6.9 & 7.6 \\
\hline 5.37 & 4.40 & 3.56 & 2.97 & 2.5 & 2.9 & 3.4 & 2.9 & 3.4 & 4.1 & 4.6 & 5.8 & 5.2 \\
\hline 4.13 & 3.32 & 2.52 & 2.14 & 1.8 & 2.1 & 2.4 & 2.0 & 2.2 & 2.7 & 2.9 & 3.7 & 3.4 \\
\hline 3.14 & 3.14 & 2.56 & 2.73 & 2.8 & 2.6 & 2.6 & 2.5 & 2.4 & 2.4 & 2.3 & 2.8 & 2.9 \\
\hline 1.65 & 1.60 & 1.53 & 1.54 & 1.6 & 1.5 & 1.5 & 1.5 & 1.5 & 1.5 & 1.4 & 1.4 & 1.5 \\
\hline 0.602 & 0.605 & 0.627 & 0.621 & 0.619 & 0.624 & 0.625 & 0.632 & 0.643 & 0.648 & 0.659 & 0.643 & 0.636 \\
\hline
\end{tabular}


TABLE 10

Average Bulk Rock Composition

\begin{tabular}{|c|c|c|c|c|c|c|}
\hline $\begin{array}{c}\text { Unit } \\
\text { No. of } \\
\text { Analyses }\end{array}$ & $A_{1}$ & $\mathrm{~A}_{2}$ & $\mathrm{~A}_{3}$ & $B_{1}$ & $\mathrm{~B}_{2}$ & C \\
\hline $\mathrm{SiO}_{2}$ & 49.08 & 49.09 & 48.82 & 48.59 & 48.15 & 49.04 \\
\hline $\mathrm{TiO}_{2}^{2}$ & 1.47 & 1.62 & 1.71 & 1.25 & 1.03 & 1.59 \\
\hline $\mathrm{Al}_{2} \mathrm{O}_{3}$ & 15.42 & 15.14 & 15.09 & 16.86 & 17.75 & 16.26 \\
\hline $\mathrm{Fe}_{2} \mathrm{O}_{3}$ & 3.02 & 3.23 & 3.18 & 3.32 & 3.21 & 3.44 \\
\hline $\mathrm{FeO}$ & 6.13 & 6.60 & 6.66 & 5.24 & 4.38 & 6.12 \\
\hline $\mathrm{MnO}$ & 0.16 & 0.18 & 0.15 & 0.15 & 0.13 & 0.16 \\
\hline $\mathrm{MgO}$ & 7.77 & 7.69 & 7.53 & 7.36 & 7.74 & 6.83 \\
\hline $\mathrm{CaO}$ & 11.55 & 11.12 & 10.73 & 11.76 & 12.01 & 11.45 \\
\hline $\mathrm{Na}_{2} \mathrm{O}$ & 2.58 & 2.69 & 2.83 & 2.51 & 2.42 & 2.91 \\
\hline $\mathrm{K}_{2} \mathrm{O}$ & 0.22 & 0.23 & 0.22 & 0.18 & 0.18 & 0.39 \\
\hline $\mathrm{P}_{2} \mathrm{O}_{5}$ & 0.15 & 0.16 & 0.16 & 0.12 & 0.12 & 0.16 \\
\hline $\mathrm{H}_{2} \mathrm{O}(+)$ & 1.30 & 1.16 & 1.63 & 1.29 & 1.49 & 0.86 \\
\hline $\mathrm{H}_{2}^{2} \mathrm{O}(-)$ & 1.00 & 0.92 & 1.26 & 1.40 & 1.45 & 0.82 \\
\hline Total & 99.85 & 99.83 & 99.97 & 100.03 & 100.06 & 100.03 \\
\hline or & 1.3 & 1.4 & 1.3 & 1.1 & 1.1 & 2.4 \\
\hline$a b$ & 22.4 & 23.3 & 24.7 & 21.9 & 21.1 & 25.1 \\
\hline an & 30.7 & 29.3 & 28.7 & 35.2 & 38.2 & 30.7 \\
\hline wo & 11.3 & 11.0 & 10.5 & 10.1 & 9.4 & 10.9 \\
\hline en & 14.5 & 14.0 & 13.4 & 12.9 & 11.6 & 9.4 \\
\hline fs & 8.8 & 9.2 & 8.8 & 7.8 & 5.9 & 6.6 \\
\hline fo & 3.8 & 3.9 & 4.2 & 4.2 & 5.8 & 5.6 \\
\hline $\mathrm{fa}$ & 2.5 & 2.8 & 3.0 & 2.8 & 3.3 & 4.4 \\
\hline $\mathrm{mt}$ & 1.5 & 1.6 & 1.6 & 1.4 & 1.2 & 1.5 \\
\hline il & 2.9 & 3.2 & 3.4 & 2.4 & 2.0 & 3.1 \\
\hline ap & 0.4 & 0.4 & 0.4 & 0.3 & 0.3 & 0.4 \\
\hline $\mathrm{Mg} /(\mathrm{Mg}+\mathrm{Fe})$ & 0.635 & 0.616 & 0.610 & 0.639 & 0.678 & 0.595 \\
\hline
\end{tabular}

Note: In the calculation of C.I.P.W. norm and $\mathrm{Mg} /(\mathrm{Mg}+\mathrm{Fe})$ ratio, oxidation index is assumed to be 0.1 .

TABLE 12

Cs Contents of Hole 396B Basalts

\begin{tabular}{lccc}
\hline $\begin{array}{c}\text { Sample } \\
\text { (Interval in cm) }\end{array}$ & Piece No. & Cs (ppm) & $\sigma$ \\
\hline $4-1,126-127$ & 12 & 0.031 & 0.004 \\
$10-1,49-56$ & $9 \mathrm{~A}$ & 0.051 & 0.001 \\
$14-1, \quad 3-5$ & 1 & 0.051 & 0.008 \\
\hline
\end{tabular}

Note: Data represent average of two measurements by neutron activation method. The analyzed samples are fresh sideromelane glass.
TABLE 11

Average Glass Composition

\begin{tabular}{|c|c|c|c|c|c|c|}
\hline Unit & $A_{1}$ & $\mathrm{~A}_{2}$ & $\mathrm{~A}_{3}$ & $\mathrm{~B}_{1}$ & $\mathrm{~B}_{2}$ & $\mathrm{C}$ \\
\hline $\begin{array}{c}\text { No. of } \\
\text { Analyses }\end{array}$ & 4 & 7 & 2 & 6 & 4 & 1 \\
\hline $\begin{array}{l}\mathrm{SiO}_{2} \\
\mathrm{TiO}\end{array}$ & 50.9 & 51.0 & 50.6 & 50.8 & 50.9 & 50.9 \\
\hline $\mathrm{TiO}_{2}$ & 1.40 & 1.54 & 1.65 & 1.39 & 1.25 & 1.51 \\
\hline $\mathrm{Al}_{2} \mathrm{O}_{3}$ & 15.5 & 15.6 & 15.6 & 15.3 & 15.6 & 16.4 \\
\hline $\mathrm{FeO}^{*}$ & 9.14 & 9.56 & 10.09 & 9.48 & 8.84 & 9.08 \\
\hline $\mathrm{MnO}$ & 0.16 & 0.16 & 0.16 & 0.18 & 0.18 & 0.16 \\
\hline $\mathrm{MgO}$ & 8.49 & 8.09 & 7.75 & 7.92 & 8.29 & .14 \\
\hline $\mathrm{CaO}$ & 11.42 & 11.19 & 10.74 & 11.57 & 12.13 & 11.22 \\
\hline $\mathrm{Na}_{2} \mathrm{O}$ & 2.77 & 2.81 & 3.12 & 2.76 & 2.69 & 3.00 \\
\hline $\mathrm{K}_{2} \mathrm{O}$ & 0.10 & 0.11 & 0.11 & 0.11 & 0.16 & 0.16 \\
\hline Total & 99.9 & 100.1 & 99.8 & 99.5 & 100.0 & 100.6 \\
\hline or & 0.6 & 0.7 & 0.7 & 0.7 & 0.6 & 0.9 \\
\hline$a b$ & 23.4 & 23.7 & 26.4 & 23.4 & 22.7 & 25.2 \\
\hline an & 29.6 & 29.6 & 28.3 & 29.1 & 30.2 & 30.6 \\
\hline wo & 11.3 & 10.8 & 10.5 & 11.9 & 12.5 & 10.3 \\
\hline en & 15.5 & 15.6 & 12.3 & 15.3 & 14.8 & 12.3 \\
\hline $\mathrm{fs}$ & 9.0 & 9.8 & 8.5 & 10.0 & 8.7 & 7.3 \\
\hline fo & 4.0 & 3.2 & 4.9 & 3.1 & 4.1 & 5.5 \\
\hline fa & 2.6 & 2.2 & 3.8 & 2.3 & 2.6 & 3.6 \\
\hline $\mathrm{mt}$ & 1.5 & 1.5 & 1.6 & 1.5 & 1.4 & 1.5 \\
\hline il & 2.7 & 2.9 & 3.1 & 2.7 & 2.4 & 2.9 \\
\hline $\begin{array}{l}\mathrm{Mg} /(\mathrm{Mg}+\mathrm{Fe}) \\
\text { mol. ratio }\end{array}$ & 0.648 & 0.626 & 0.603 & 0.623 & 0.650 & 0.640 \\
\hline ol & 0.225 & 0.221 & 0.230 & 0.211 & 0.210 & 0.229 \\
\hline $\operatorname{cpx}$ & 0.213 & 0.202 & 0.204 & 0.225 & 0.239 & 0.202 \\
\hline $\mathrm{pl}$ & 0.136 & 0.149 & 0.109 & 0.138 & 0.117 & 0.101 \\
\hline
\end{tabular}

Note: *total iron as ferrous. In calculating C.I.P.W. norm and $\mathrm{Mg} /$ $(\mathrm{Mg}+\mathrm{Fe})$ ratio, the oxidation index is assumed to be 0.1 .

TABLE 13

Miscellaneous Analyses

\begin{tabular}{|c|c|c|c|c|c|c|}
\hline \multirow{2}{*}{$\begin{array}{c}\text { Sample } \\
\text { (Interval in } \mathrm{cm} \text { ) } \\
\text { Phase }\end{array}$} & \multicolumn{2}{|c|}{$20-1,82-92(-4 F)$} & \multirow{2}{*}{$\begin{array}{l}20-1,128 \\
\quad(44 K) \\
03 \\
\text { palagonite }\end{array}$} & \multicolumn{3}{|c|}{$15-3,15-23(\approx 2 B)$} \\
\hline & $\begin{array}{l}01 \\
\text { sideromelane }\end{array}$ & $\begin{array}{l}02 \\
\text { variole }\end{array}$ & & $\begin{array}{l}04 \\
\text { smectite } \\
\text { vesicle } \\
\text { fill }\end{array}$ & $\begin{array}{l}05 \\
\text { smectite } \\
\text { after } \\
\text { glass }\end{array}$ & $\begin{array}{l}06 \\
\text { mica } \\
\text { after } \\
\text { olivine }\end{array}$ \\
\hline $\mathrm{SiO}_{2}$ & 550.9 & 50.8 & 36.4 & 49.5 & 43.2 & 56.1 \\
\hline $\mathrm{TiO}_{2}$ & 1.34 & 1.42 & 1.87 & 0.00 & 1.04 & 0.02 \\
\hline $\mathrm{Al}_{2} \mathrm{O}_{3}$ & 15.6 & 16.8 & 17.2 & 3.33 & 5.96 & 14.67 \\
\hline $\mathrm{FeO}^{*}$ & 9.22 & 9.89 & 14.2 & 12.17 & 14.65 & 9.72 \\
\hline $\mathrm{MnO}$ & 0.15 & 0.15 & 0.00 & 0.02 & 0.03 & 0.00 \\
\hline $\mathrm{MgO}$ & 8.44 & 6.11 & 1.68 & 20.4 & 15.86 & 0.75 \\
\hline $\mathrm{CaO}$ & 11.44 & 11.42 & 0.80 & 0.56 & 1.95 & 0.38 \\
\hline $\mathrm{Na}_{2} \mathrm{O}$ & 2.80 & 3.12 & 1.11 & 0.29 & 0.53 & 9.15 \\
\hline $\mathrm{K}_{2} \mathrm{O}$ & 0.11 & 0.12 & 2.32 & 0.68 & 1.22 & 0.53 \\
\hline \multirow[t]{2}{*}{ Total } & 100.0 & 99.8 & 75.5 & 87.0 & 84.4 & 91.3 \\
\hline & & & \multicolumn{4}{|c|}{ Oxygen $=22.0$} \\
\hline $\mathrm{Si}$ & & & & 7.420 & 6.832 & 7.859 \\
\hline Al & & & & 0.587 & 1.112 & 2.442 \\
\hline $\mathrm{Ti}$ & & & & 0.000 & 0.124 & 0.003 \\
\hline $\mathrm{Fe}$ & & & & 1.524 & 1.938 & 1.140 \\
\hline Mn & & & & 0.003 & 0.005 & 0.000 \\
\hline $\mathrm{Mg}$ & & & & 4.556 & 3.737 & 0.156 \\
\hline $\mathrm{Ca}$ & & & & 0.090 & 0.330 & 0.057 \\
\hline $\mathrm{Na}$ & & & & 0.083 & 0.163 & 2.486 \\
\hline K & & & & 0.131 & 0.247 & 0.094 \\
\hline Total & & & & 14.394 & 14.488 & 14.237 \\
\hline
\end{tabular}



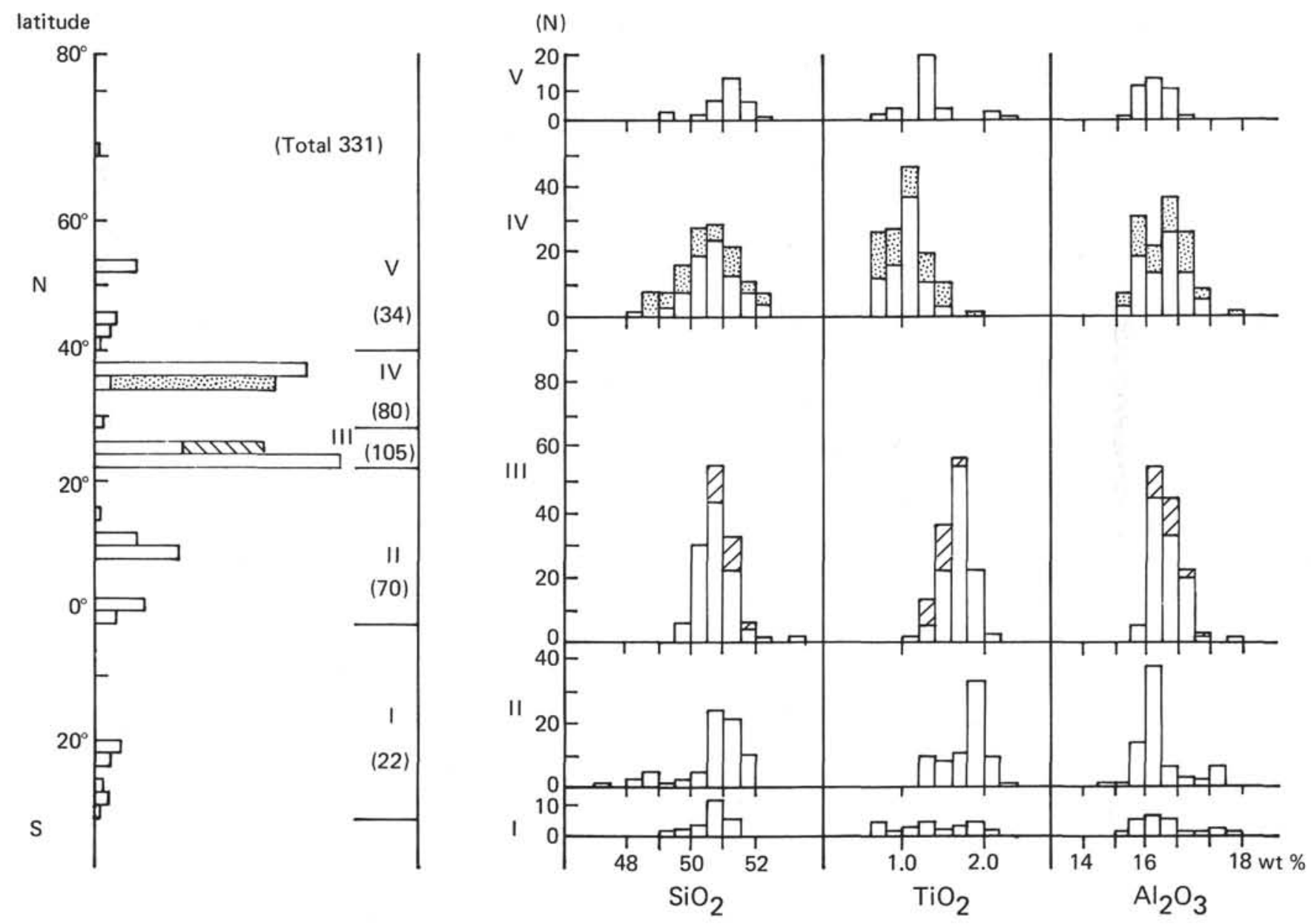

Figure 22. Composition of glass from the floor of the Atlantic Ocean. Open-bar data from Melson et al., in press; stippled-bar data of the FAMOUS Region from Bryan and Moore, 1977; and hatched-bar data represents Hole $396 B$ findings.

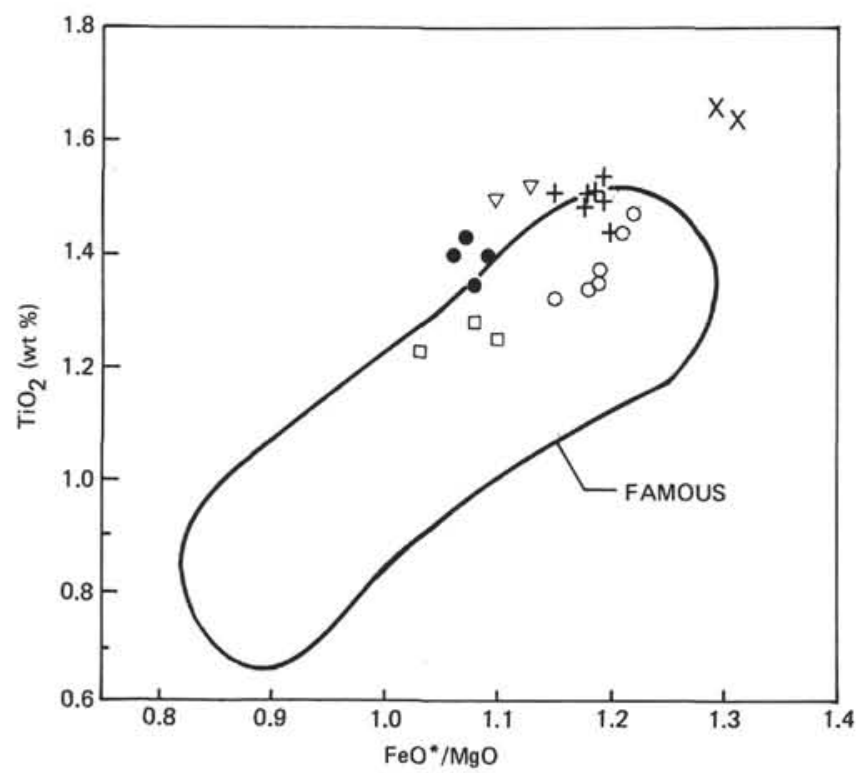

Figure 23. $\mathrm{TiO}_{2}$ versus $\mathrm{FeO} * / \mathrm{MgO}$ ratio of glass from Hole $396 B$ and FAMOUS region. 


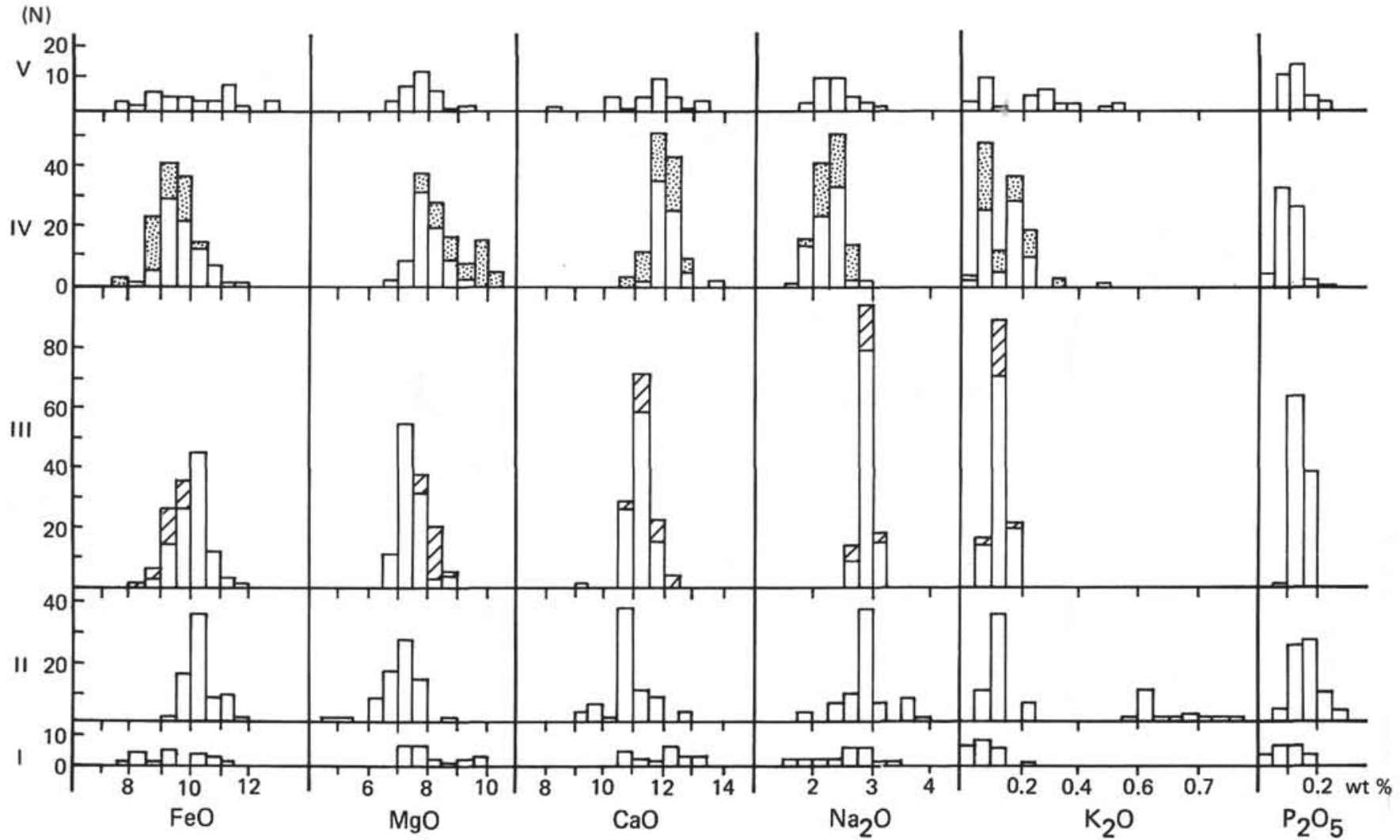

Figure 22. Continued.

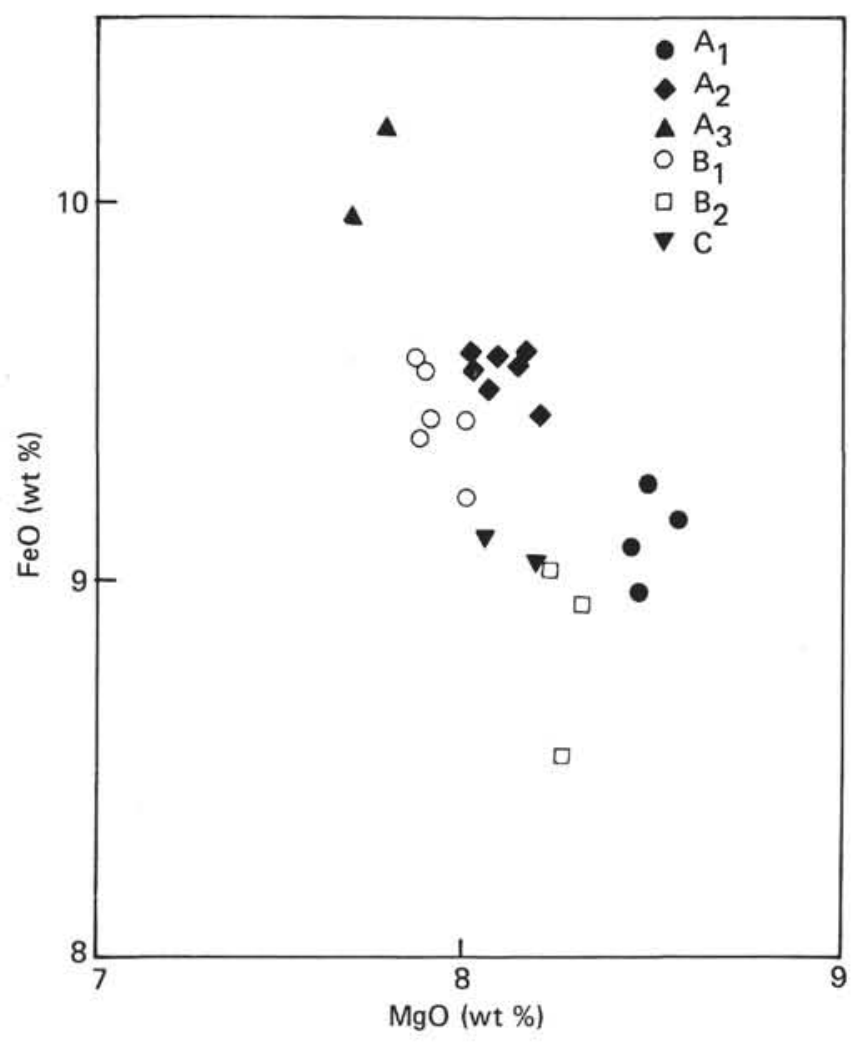

Figure 24. $\mathrm{FeO}$ versus $\mathrm{MgO}$ contents of Hole $396 \mathrm{~B}$ glass. 
TABLE 14

Fractionation Model of Leg 46 Basalts

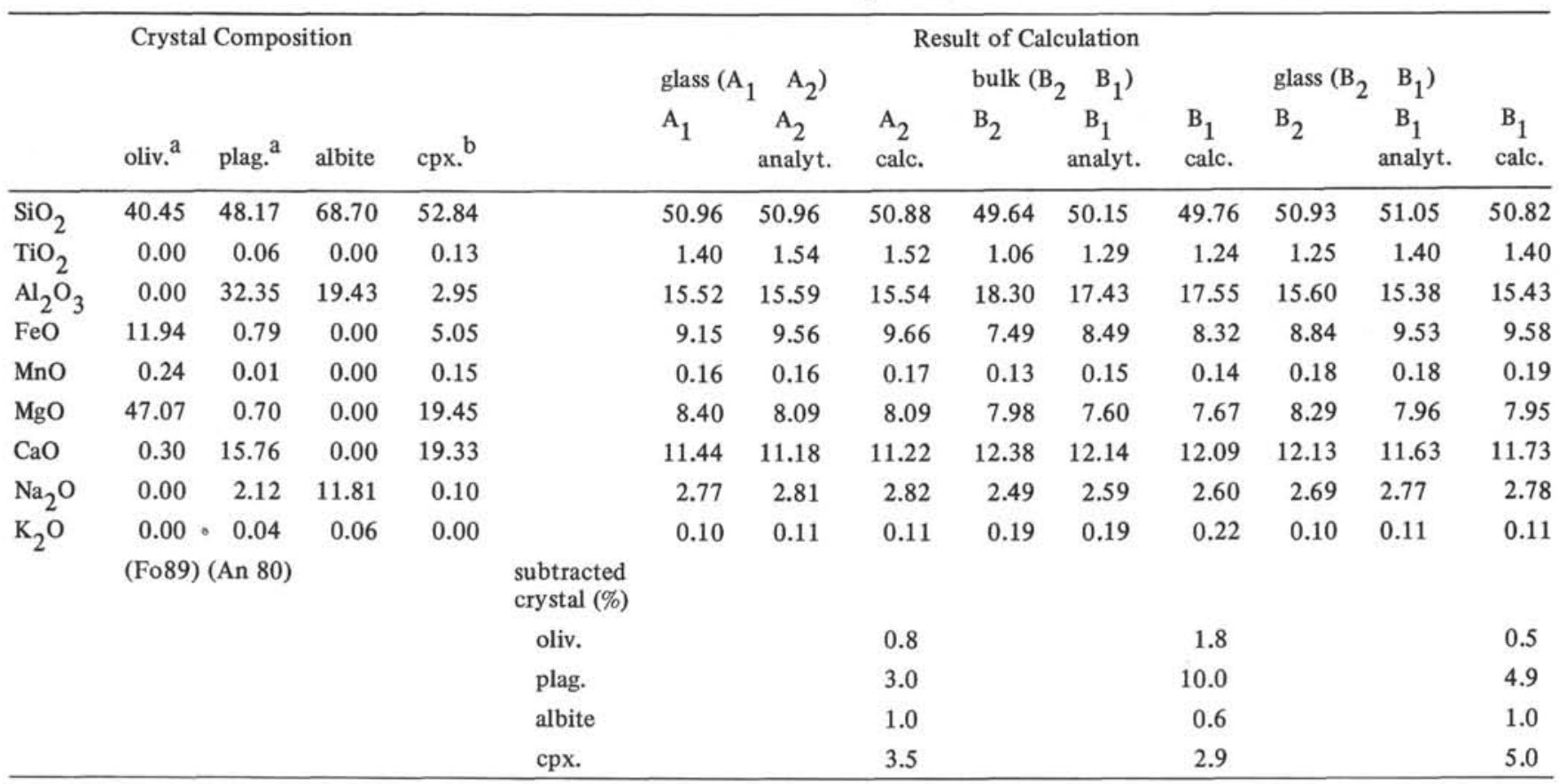

${ }^{a}$ Analyzed phenocrysts in 22-1-13, Hole 396B.

${ }^{b}$ Hodges and Papike (1976).

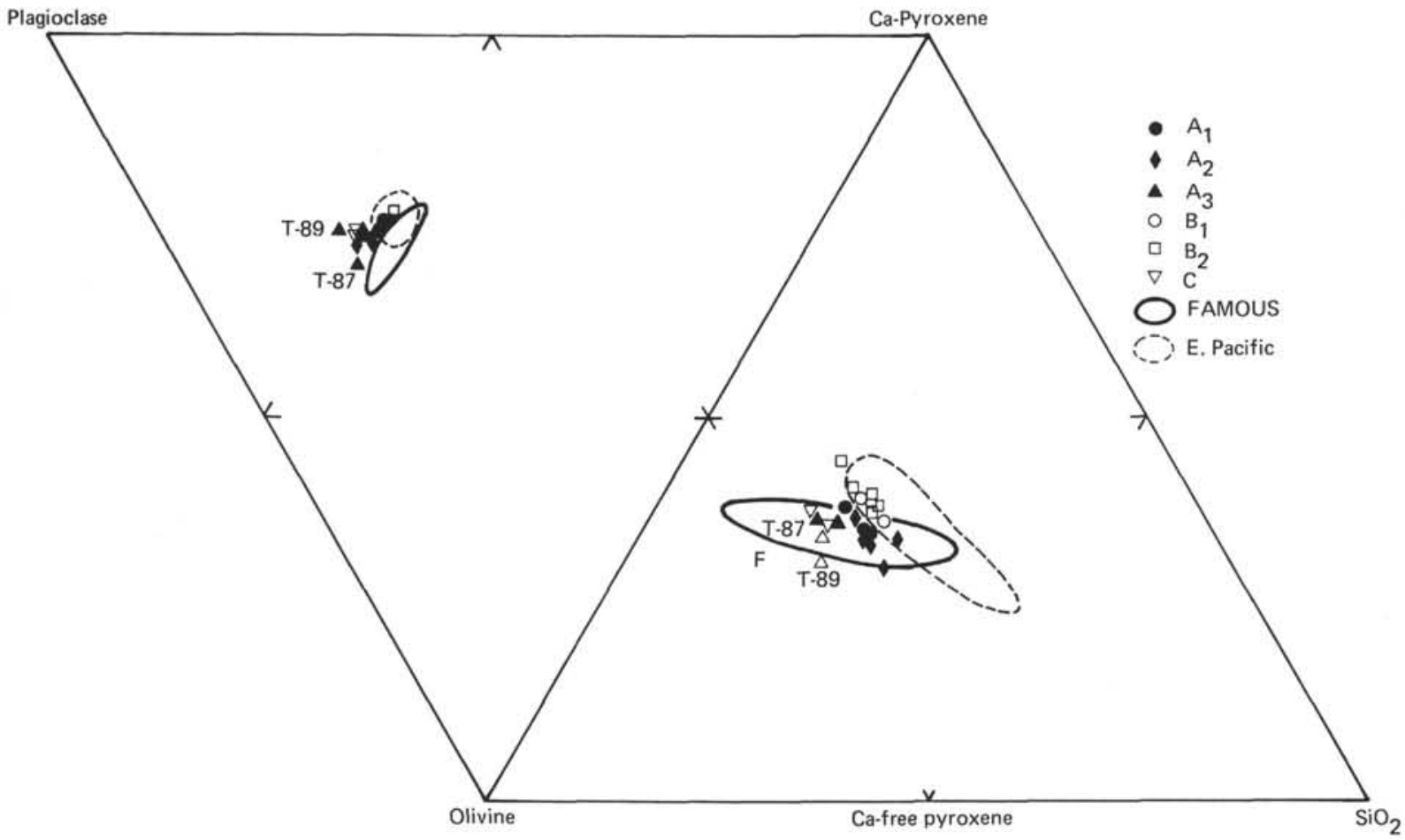

Figure 25. Glass composition of Hole 396 B and FAMOUS region and bulk rock composition of East Pacific (Clague and Bunch, 1976) in the normative tetrahedron plagioclase-Ca pyroxene-olivine-silica projected from silica apex (left triangle) and plagioclase apex (right triangle), respectively. The methods of calculation and projection are the same as those of Shibata's (1976) except for assuming the oxidation index of 0.1 for the present calculation. Note that compositional trends extends toward silica apex in the tetrahedron, which may suggest that these trends are controlled by olivine, Ca-rich clinopyroxene, and plagioclase. 


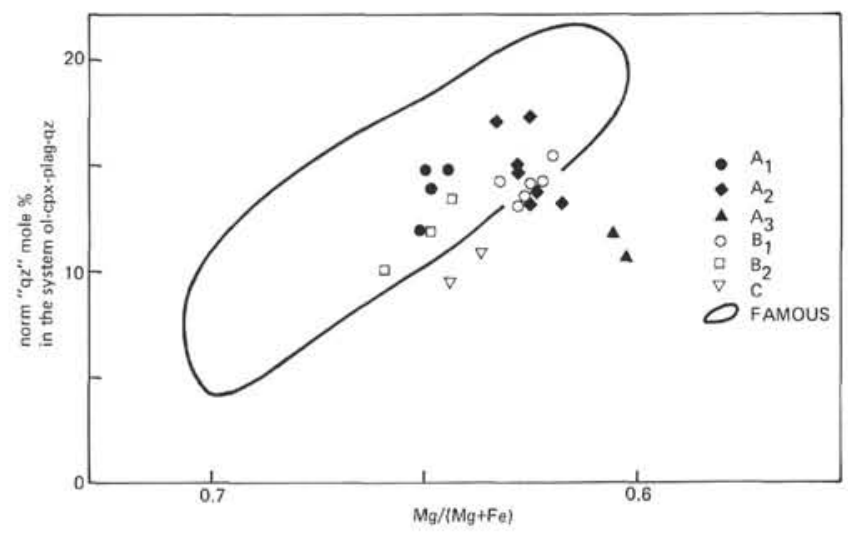

Figure 26. Composition of glass of Hole $396 B$ and FAMOUS region, showing the positive correlation between $\mathrm{Mg} /(\mathrm{Mg}+\mathrm{Fe})$ ratio and the normative "quartz" content in the tetrahedron (Figure 25).

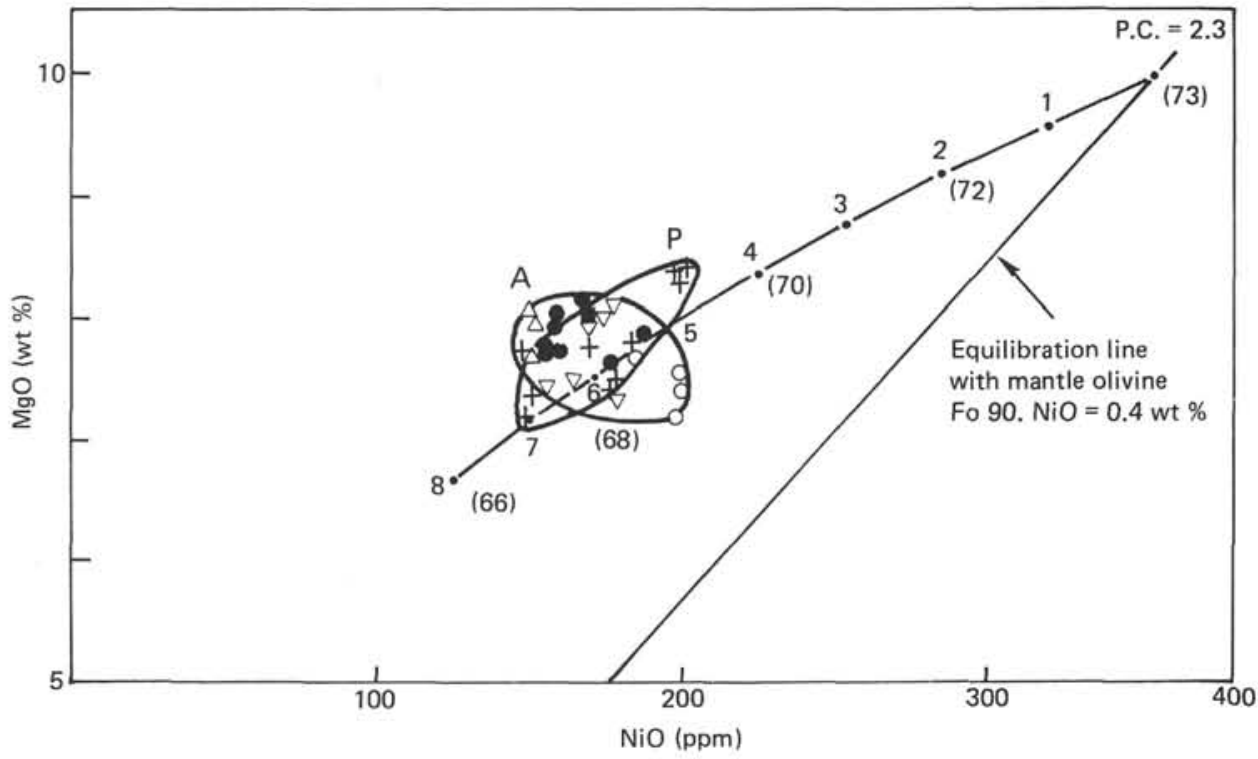

Figure 27. $\mathrm{MgO}$ versus NiO contents of Hole $396 \mathrm{~B}$ basalt (Leg 46 Shipboard Party, this volume). Dotted line represents the compositional variation of basalt during fractional crystallization of olivine (see text).

TABLE 15

Estimated Temperature of Leg 46 Basaltic Magmas $\left({ }^{\circ} \mathrm{C}\right)$

\begin{tabular}{|c|c|c|c|c|c|c|}
\hline Chemical Unit & $\mathrm{A}_{1}$ & $\mathrm{~A}_{2}$ & $\mathrm{~A}_{3}$ & $\mathrm{~B}_{1}$ & $\mathrm{~B}_{2}$ & $\mathrm{C}$ \\
\hline $\begin{array}{l}\text { 1-atm, dry } \\
0.5 \text { kilobars }\end{array}$ & 1217 & 1208 & 1202 & 1205 & 1210 & 1207 \\
\hline 0.3 wt. $\% \mathrm{H}_{2} \mathrm{O}$ & 1208 & 1199 & 1193 & 1196 & 1201 & 1198 \\
\hline
\end{tabular}




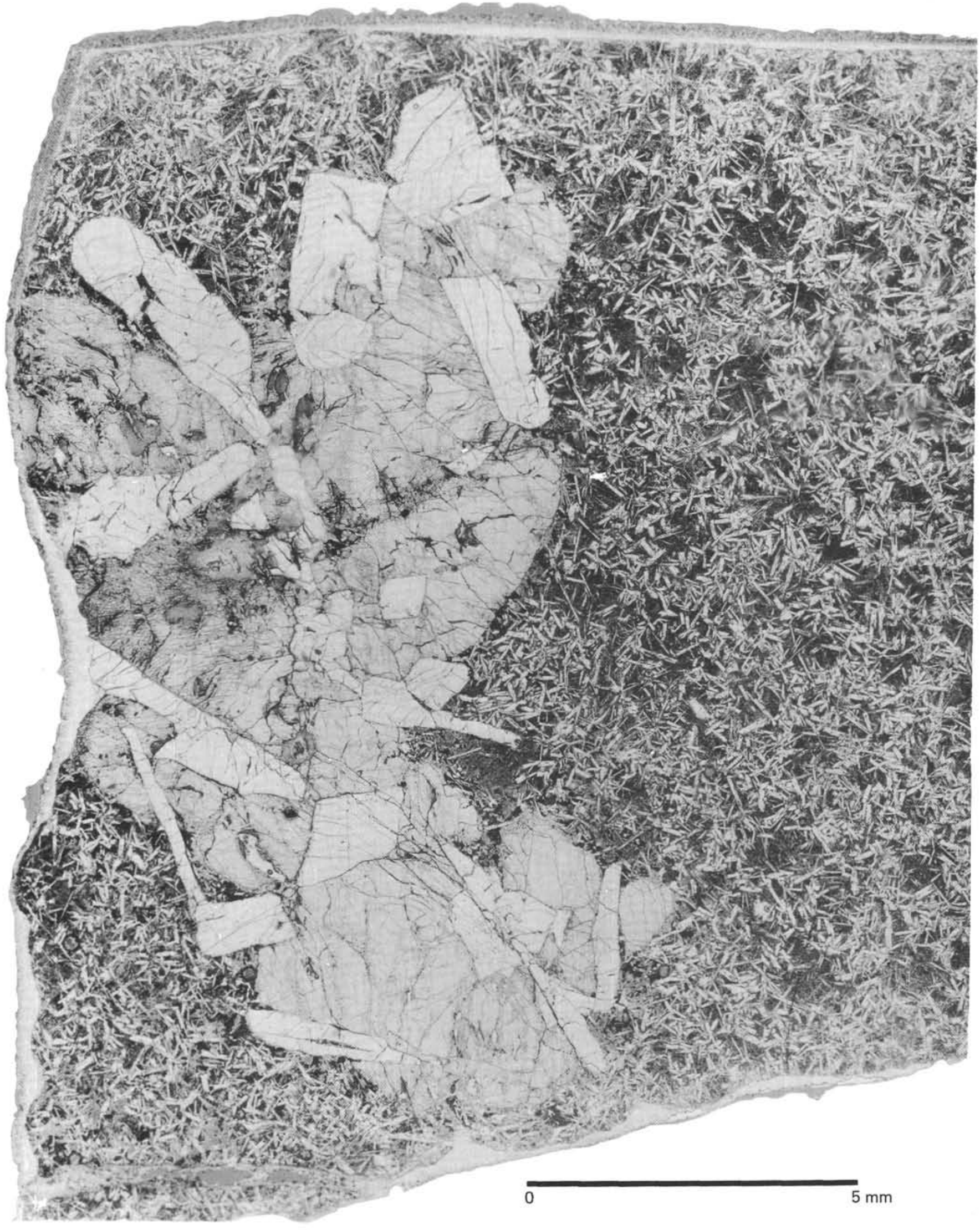

PLATE 1

Ca-rich clinopyroxene-plagioclase crystal clot in Sample 396B-15-5, $70-76 \mathrm{~cm}$. 